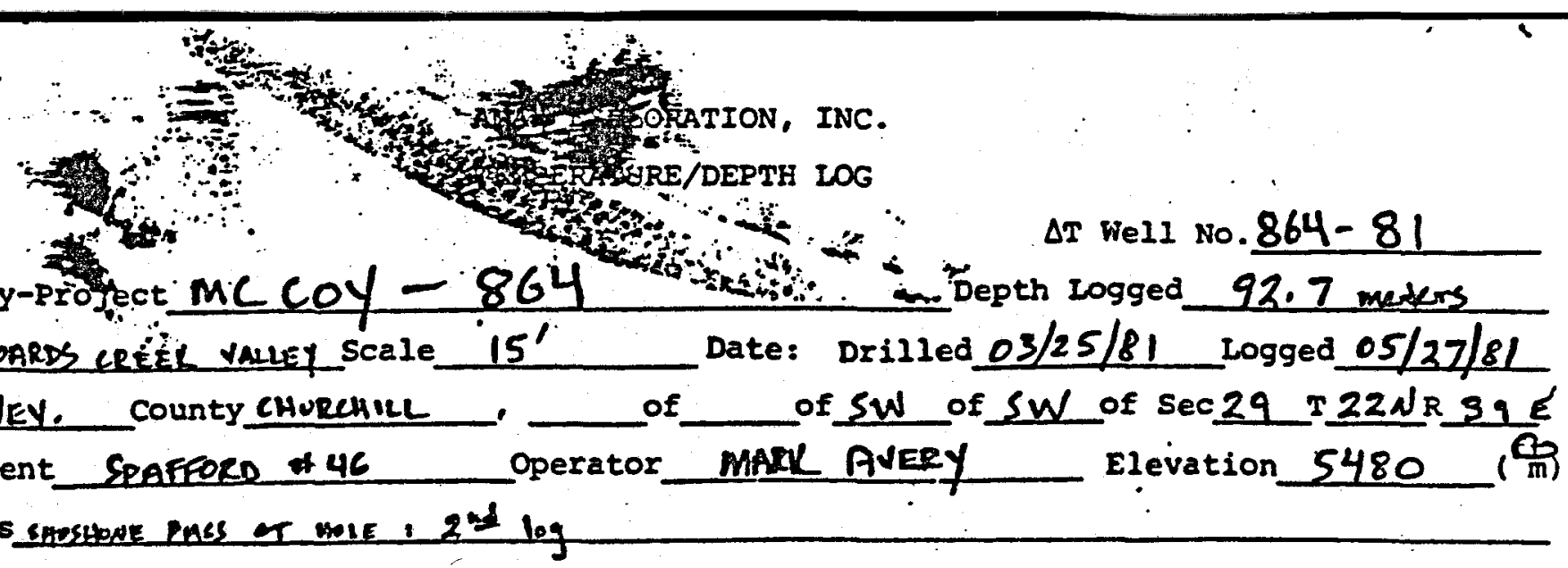

\title{
Date Logged
}

itstify Proj No Well No DA MO YR

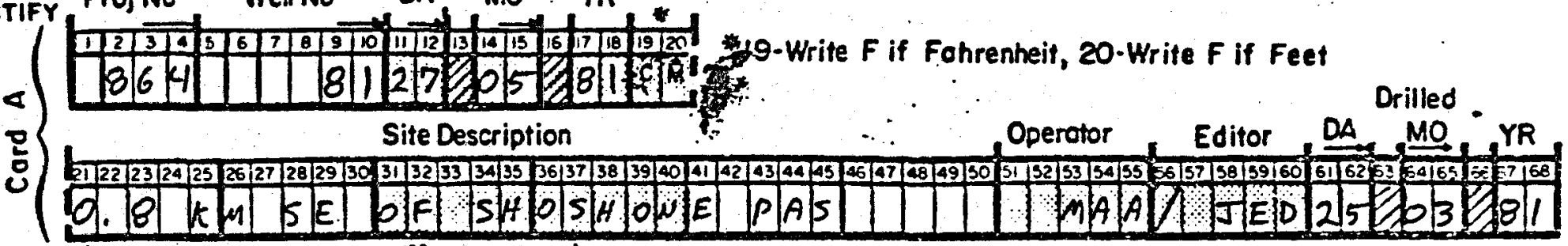

(Approx. locotion, woter well?, oil test?, etc).

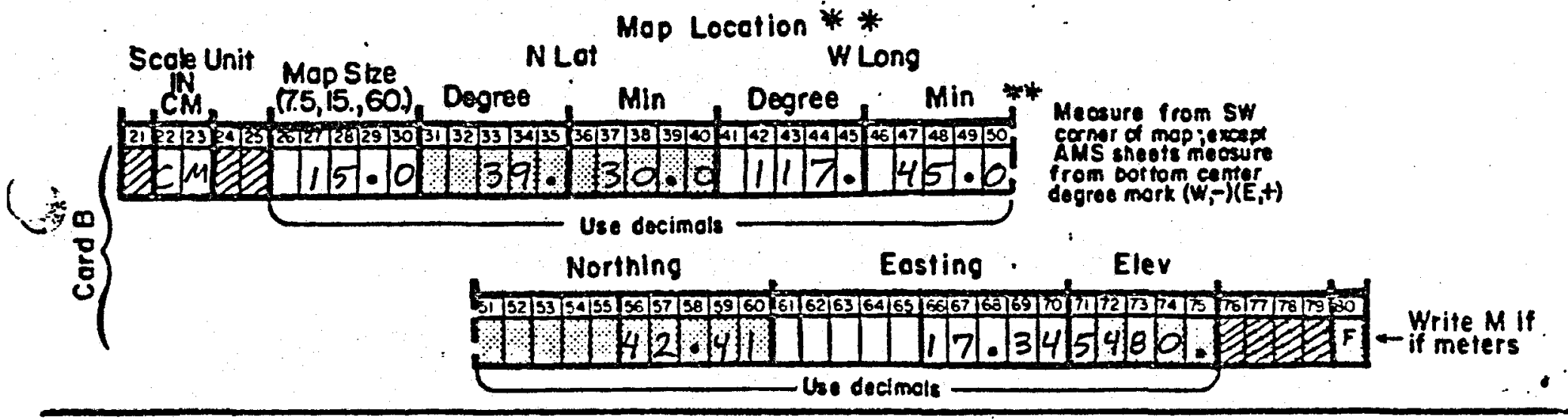

Segment $:=$ Depths

Stort
Conductivity

End
Best cond. $(-K)$

$\forall K \quad J \quad$ Downword extropolo

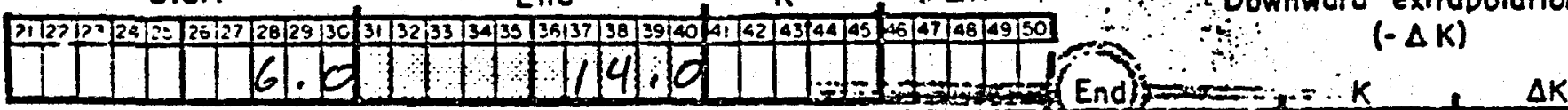

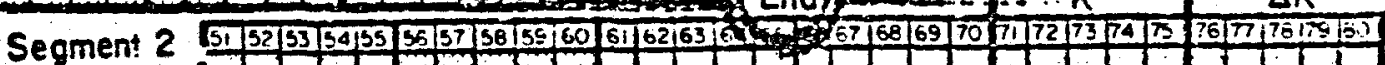

Segment 3

Stort $\longrightarrow 1$

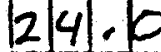

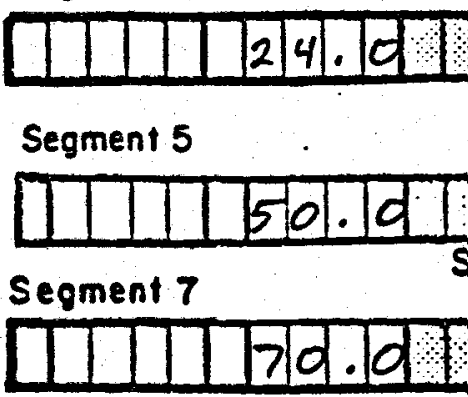

Segment 9

Segment 4

Start

14,.10

$\underset{\text { Segment } 6}{\longrightarrow} 11216 / 260$

1921.0 $-4.181 .7-15$

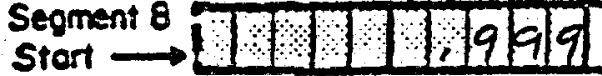

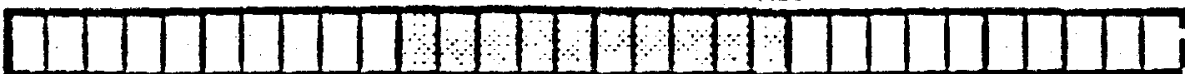

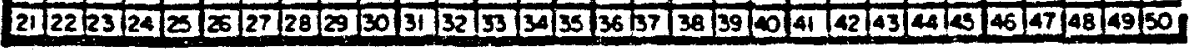

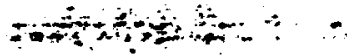

After final segment 


\section{DISCLAIMER}

This report was prepared as an account of work sponsored by an agency of the United States Government. Neither the United States Government nor any agency Thereof, nor any of their employees, makes any warranty, express or implied, or assumes any legal liability or responsibility for the accuracy, completeness, or usefulness of any information, apparatus, product, or process disclosed, or represents that its use would not infringe privately owned rights. Reference herein to any specific commercial product, process, or service by trade name, trademark, manufacturer, or otherwise does not necessarily constitute or imply its endorsement, recommendation, or favoring by the United States Government or any agency thereof. The views and opinions of authors expressed herein do not necessarily state or reflect those of the United States Government or any agency thereof. 


\section{DISCLAIMER}

Portions of this document may be illegible in electronic image products. Images are produced from the best available original document. 
Date Logged: $05 / 27 / 81$

$\Delta T$ Well No. $864-81$

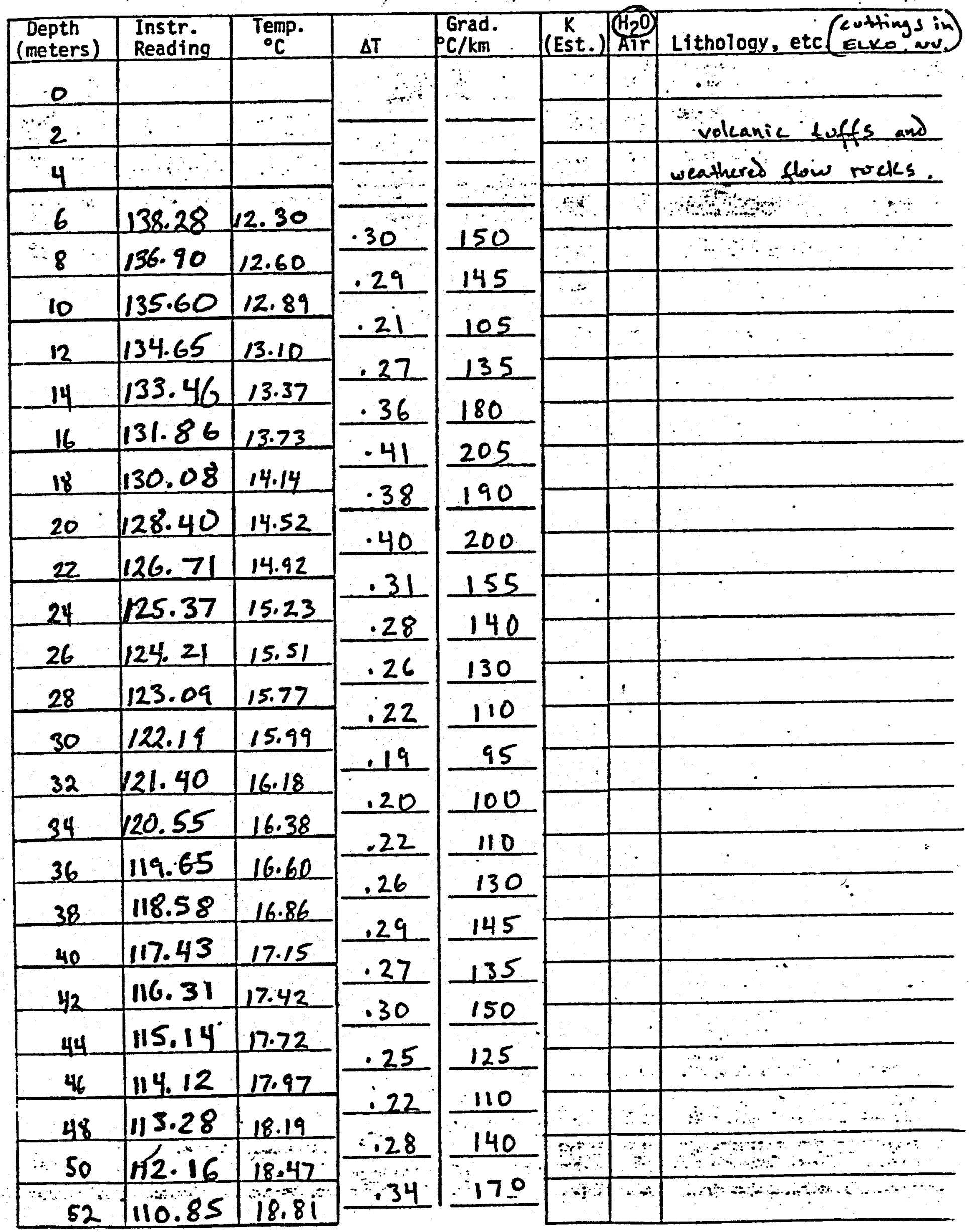


10

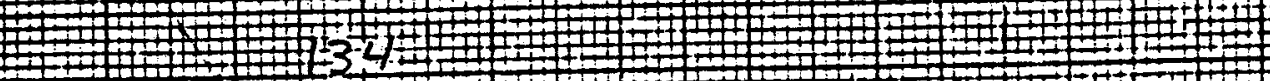
HOLE $864-81$ 20 1 W

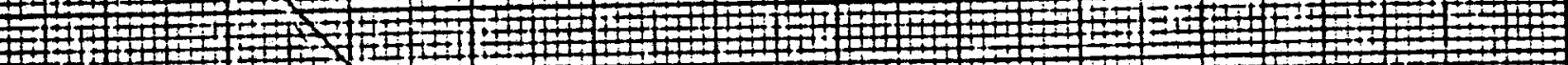

20 W

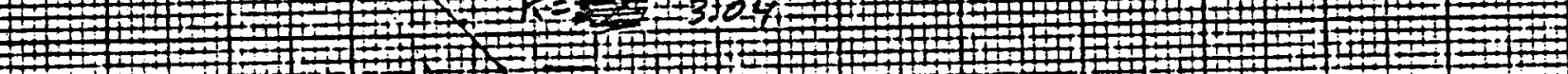

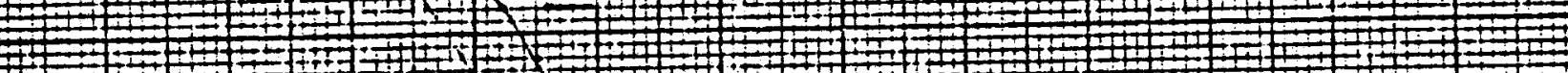

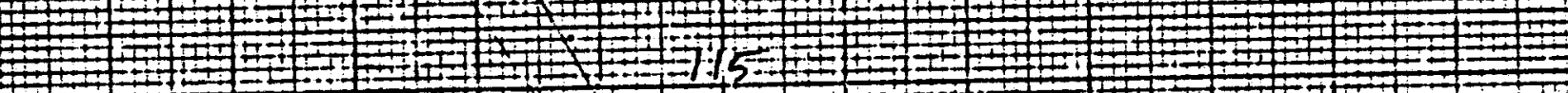

30 W

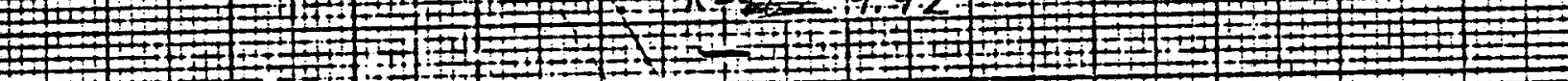

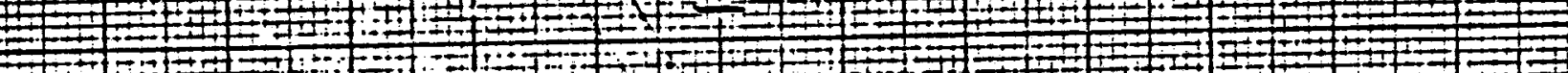

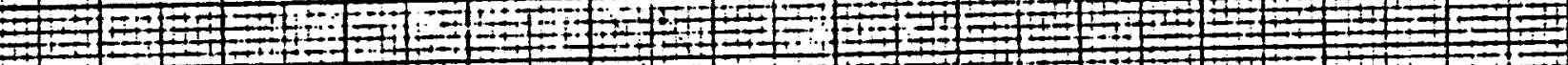

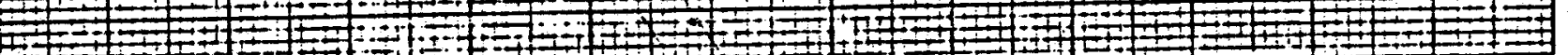

40

50

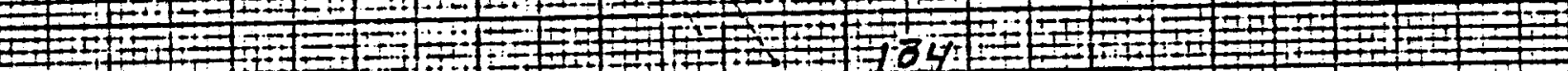

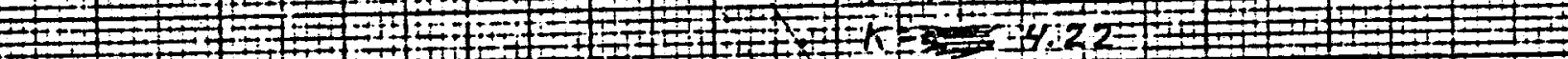

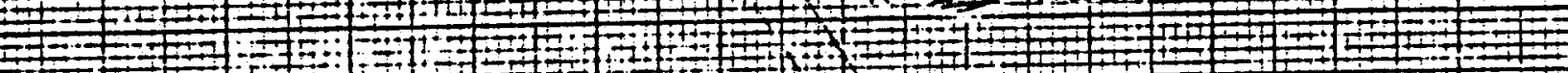

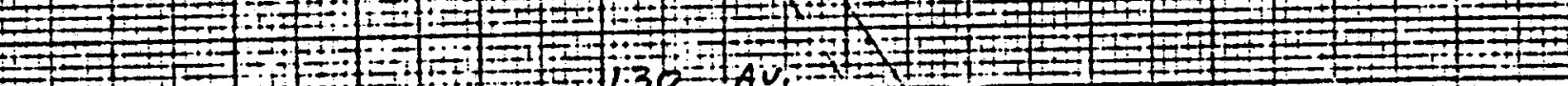

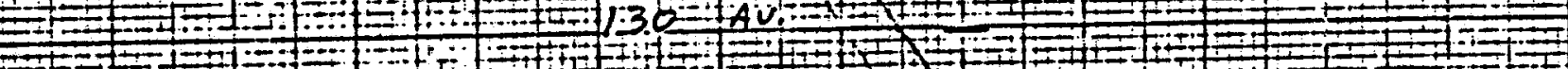

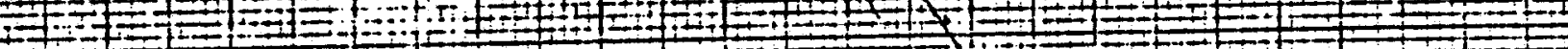

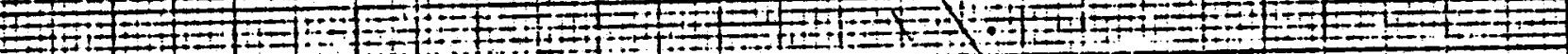

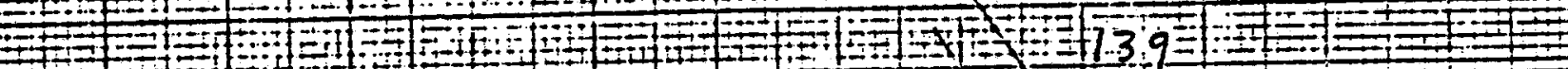

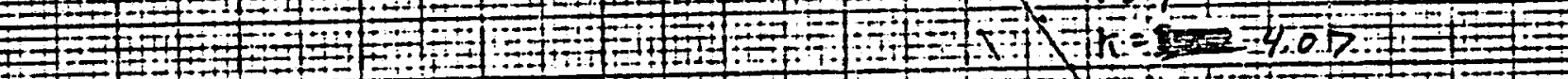

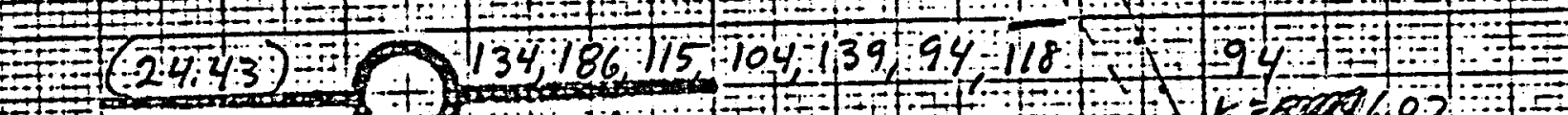
Af

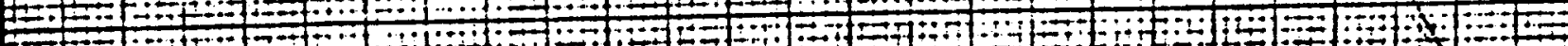

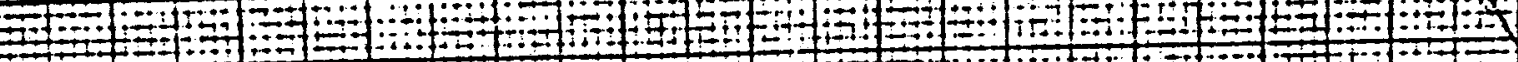

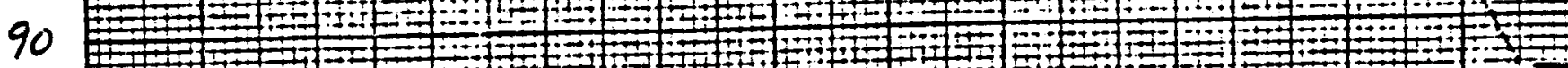

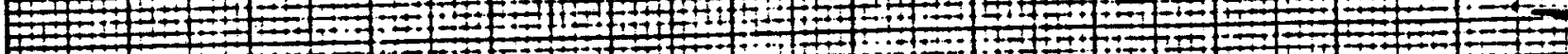

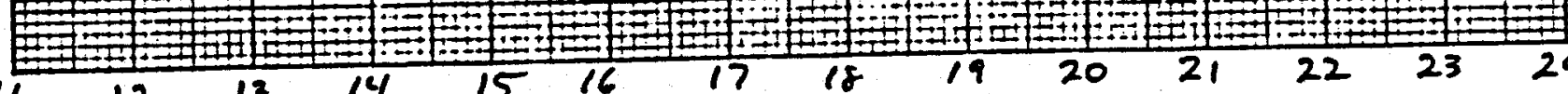




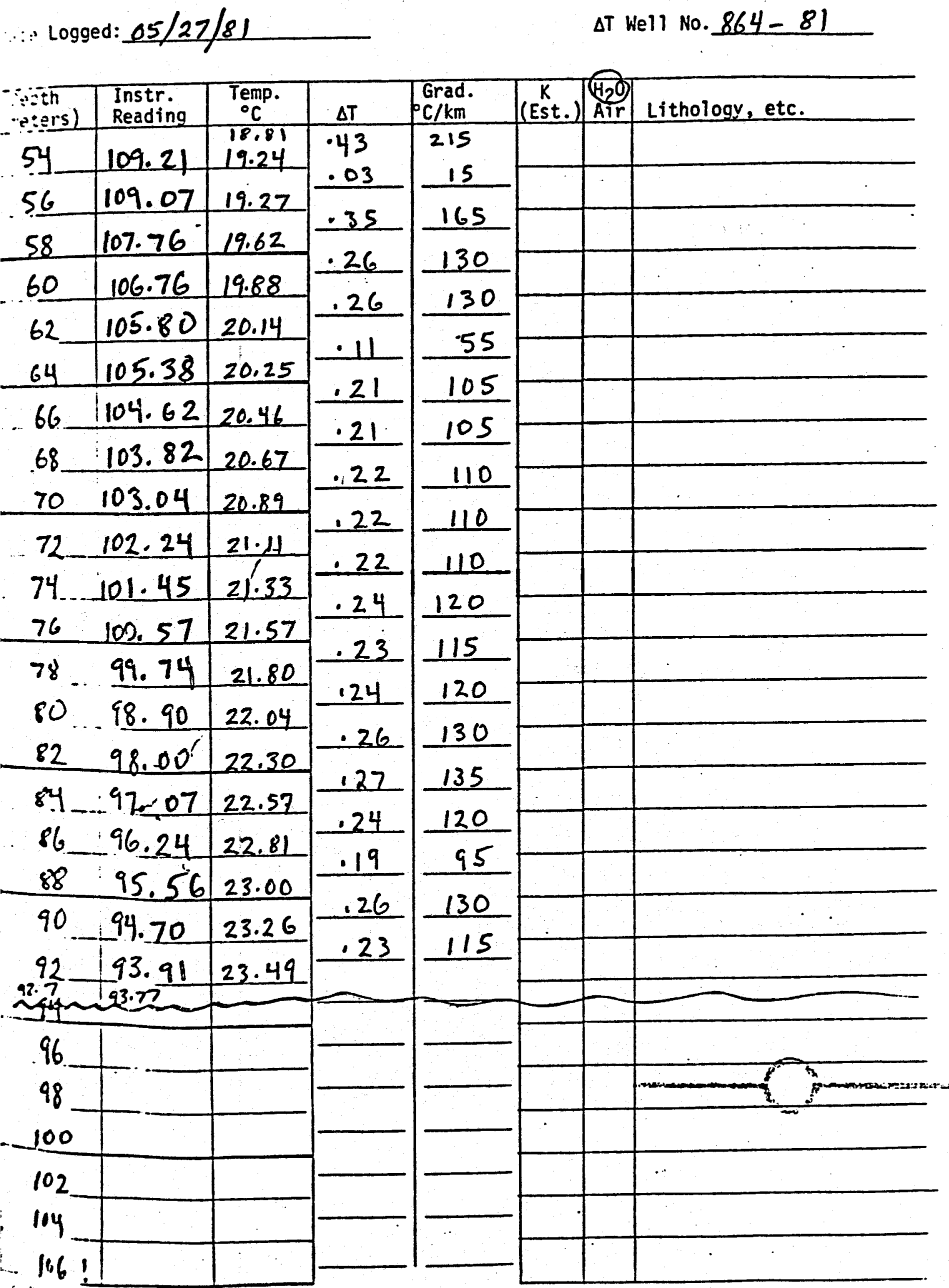




Project: 864 (MeCoy)

Hole:

81

Elevation: $\quad 5480^{\prime} \mathrm{MSL}$

Location: SW 1/4 SW 1/4 Sec 29 T22N R39E

Geologist:

Mark Avery
Date Drilled:

$3 / 25 / 81$

Method: air/foam injection

Gama:

$N / A$

(TD $=91.46$ meters $)$

Depth $(m)$

0- 3 Overburden

3-13 Altered gray-grayish white very fine-grained to fc ash-fall and $x$-tal ashflow tuffs. Most chips crumble easily with alteration of feldspars to white montmorillic clay. Iron staining present. Relic phenocrysts in $x-t a l$ ashflow tuffs often replaced with iron oxides. Mafteminerals (biotite) and hornblende (present as elongated phenocrysts) in altered ashflow tuffs.

13-16 Highly altered and iron-stained tuffs and tuffaceous sediments. Latter contains rounded gravels of ashflow tuffs as in $3-13 \mathrm{~m}$.

16-30 White beige tuffaceous sediments. Very fine-grained, banded with alternating white/beige laminae. High content of clay.

30-36 (As in 13-16m).

36-60 White-gray thinly bedded to laminated tuffaceous sediments.

60-70 More gray tuffaceous sediments as before with $40 \%$ hornblende (phenocrysts $0 \rightarrow \square$ in shape) rich altered tuffs (also gray in color).

70-91.46 White to gray banded and laminated tuffaceous sediments (rarely as thin beds) with $10-20 \%$ altered $x$-tal tuffs (gray). Very soft and light, crumbles easily. High clay content. 
- AMAX EXPLORATION, INC.

TEMPERATURE/DEPTH LOG

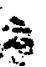

Property-Project MCCOY - 864

$\Delta T$ Well No. $864-82$

Map enaros cocer muEy scale $15^{\circ}$ Depth Logged 45.6 meters State NEY Countychurelice of $S W$ of NW of NW of Sec 3 T21NR $39 E$

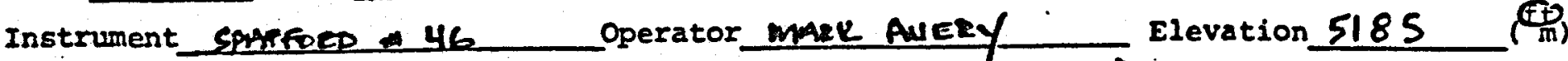

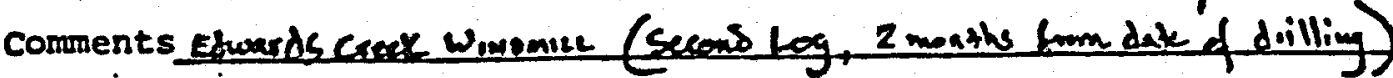

\section{Dote Logged}

itustify Proj No Well No DA MO YR

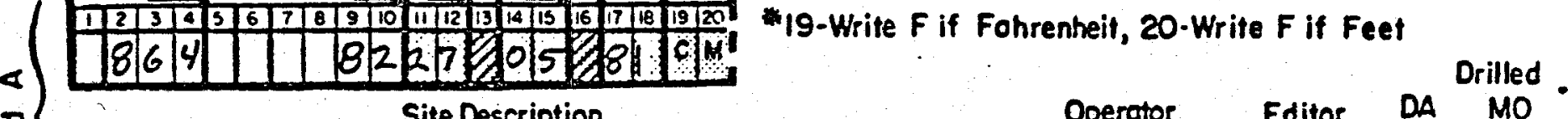

웅

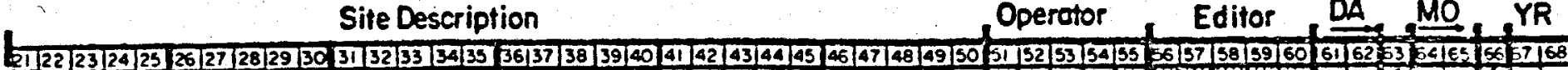

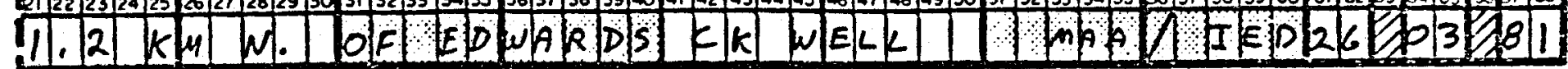
(Approx. locotion, woter well?, oll rest?, ete).

Scok Unit Map Size NLot Mop Locotion * * WLong 21M, $(7.5,15,60)$, Dogree, Min, Degree, Min ** Meoure from sw 竞

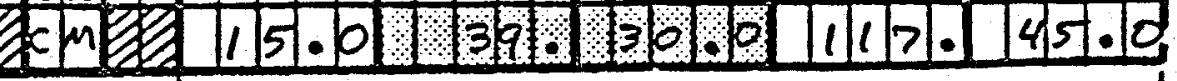
cormir a mapiexap seats meosure trom bottom conter

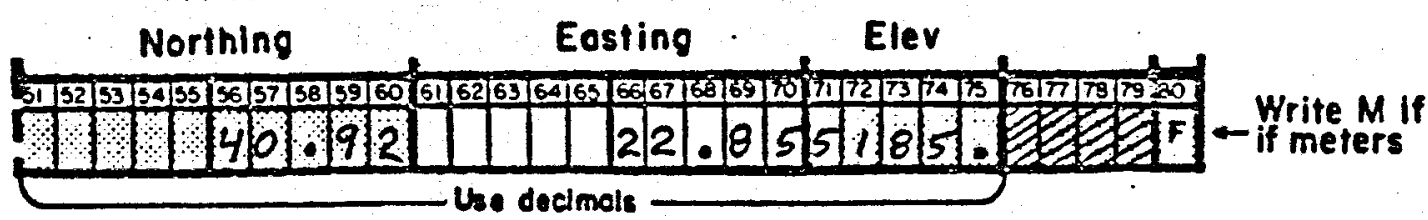

Segment $!=$ Depths

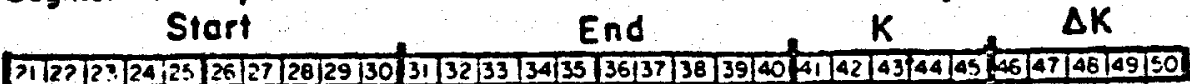

Conductivity

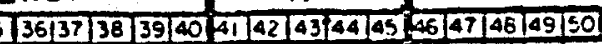

Best cond. $(-K)$

Downword extropolotions $(-\Delta K)$

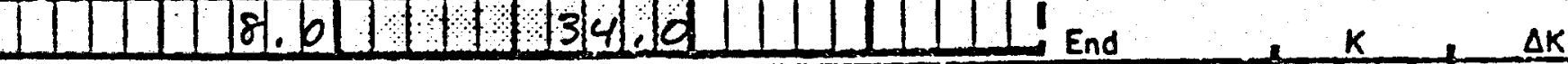

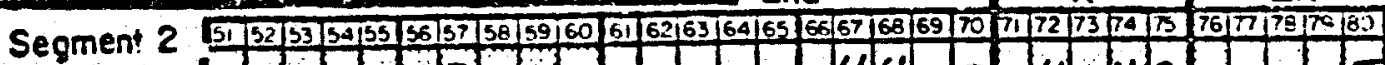

Segment 3

stort $\rightarrow 111 \backslash 13,4.10$

4414. $0 \mathrm{~A} 44.419$ $-15$

प11 II L lalala

Segment 5

TT

Segment 7

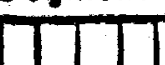

Segment 9

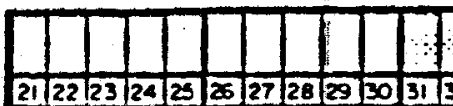

211221232425 2627282030 31 3

Segment 4
Stort $\rightarrow$

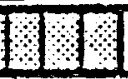

C

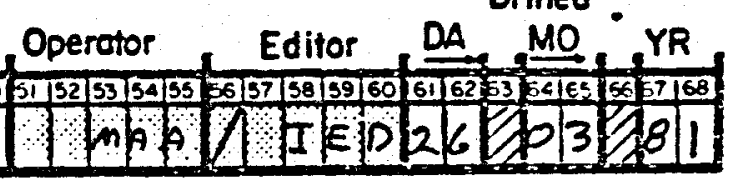


Q

10

W W $1+1$

\section{HOLE $864-82$}

20

30

40

$+2$

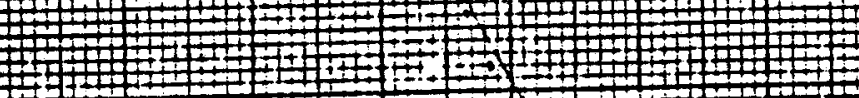

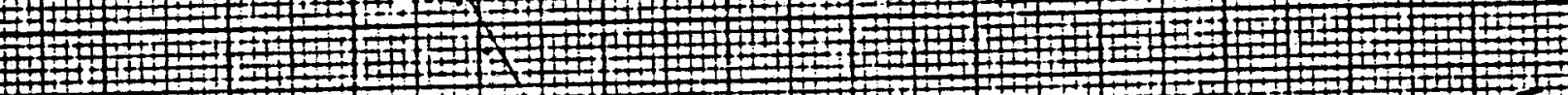

$1+10$

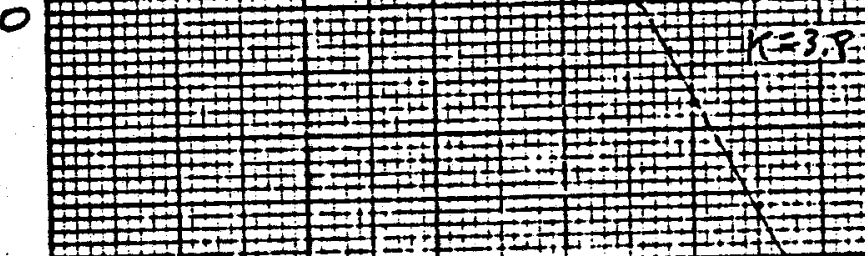

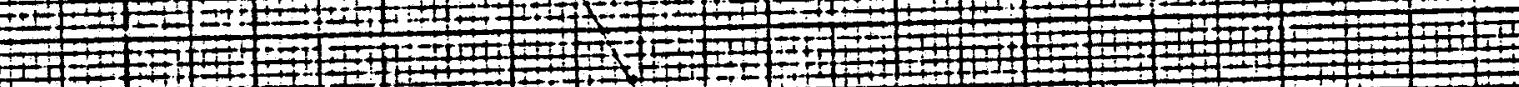

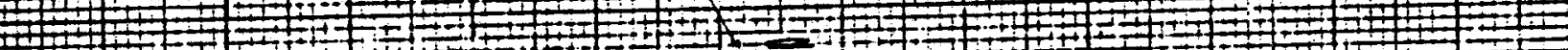

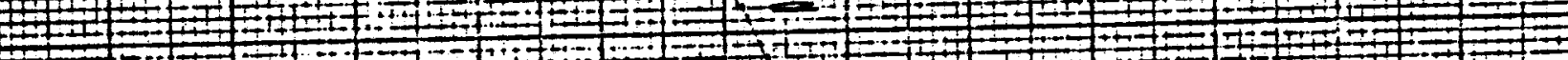

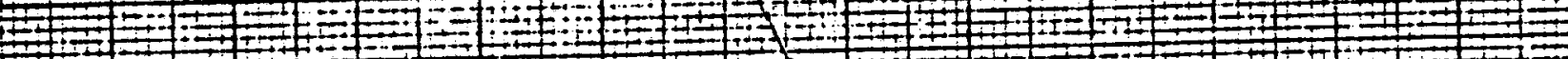

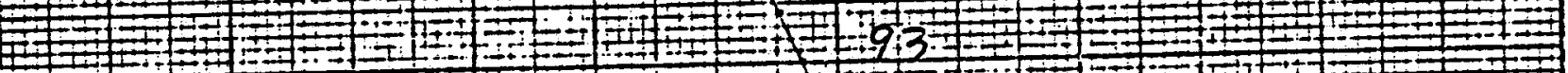

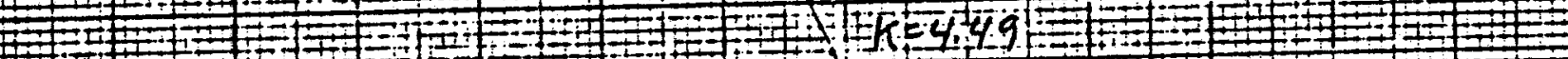

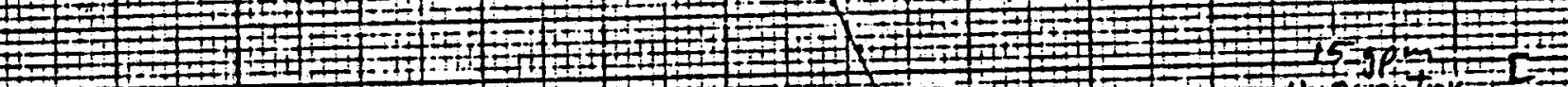

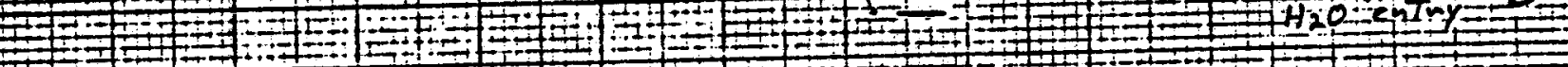

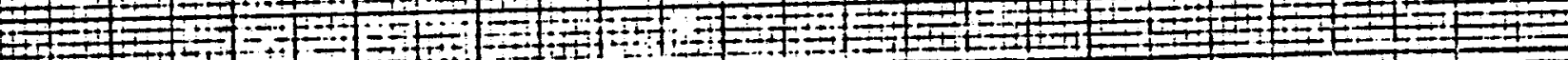

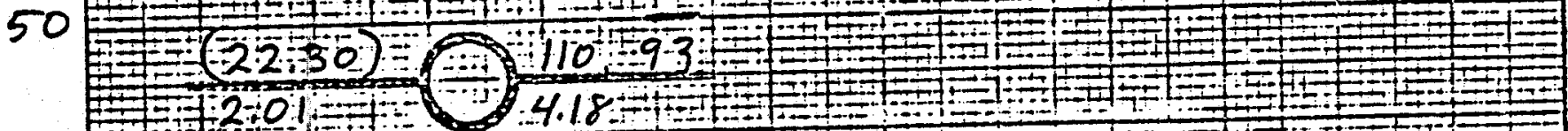

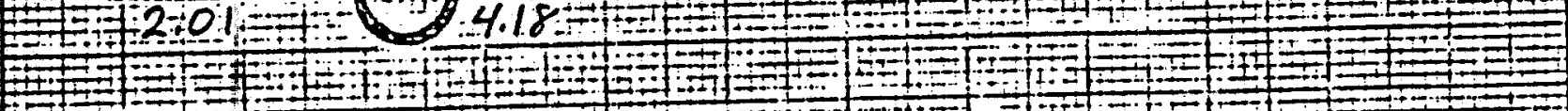

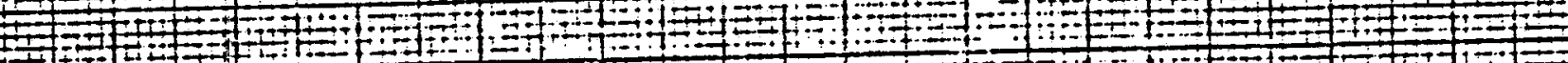

60

DEPTH

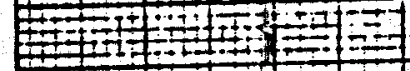
$7+1 \pm 10$

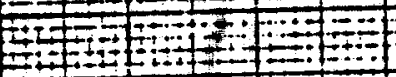

70

-1 $=-1$ -

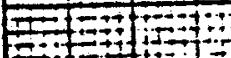

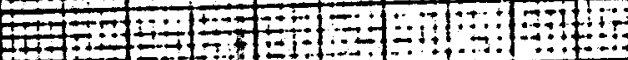

$21 \div \div$

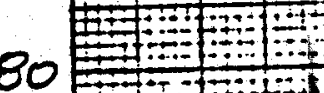

:-1:-

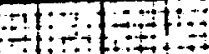

$+\frac{1+2}{10}$

$201+10$

$\because \because 0$

$\because \therefore$

$\therefore 0$

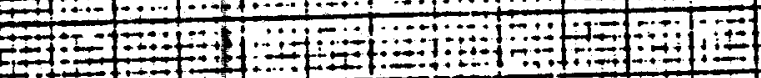

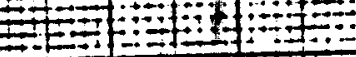

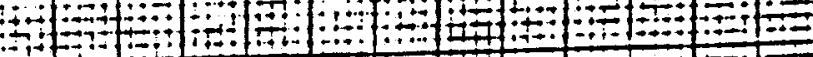

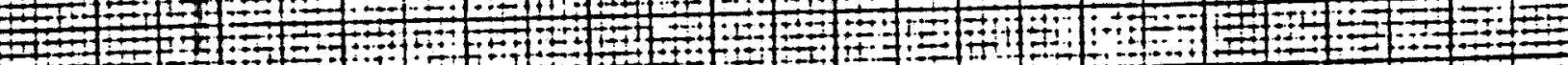

90

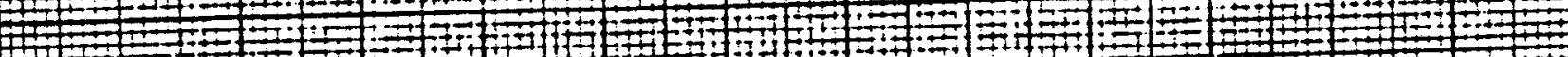

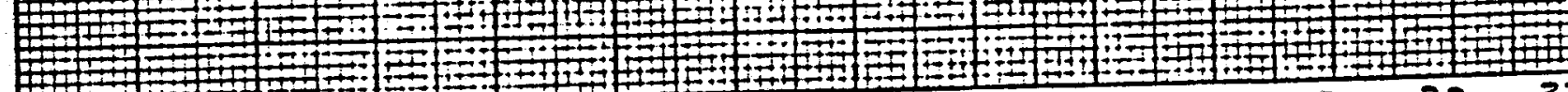
$\begin{array}{lllllllllllllllllll} & 11 & 12 & 13 & 14 & 15 & 16 & 17 & 18 & 19 & 20 & 21 & 22 & 23\end{array}$ 
Date Logged: $05 / 27 / 81$

هT Well No. $864-82$

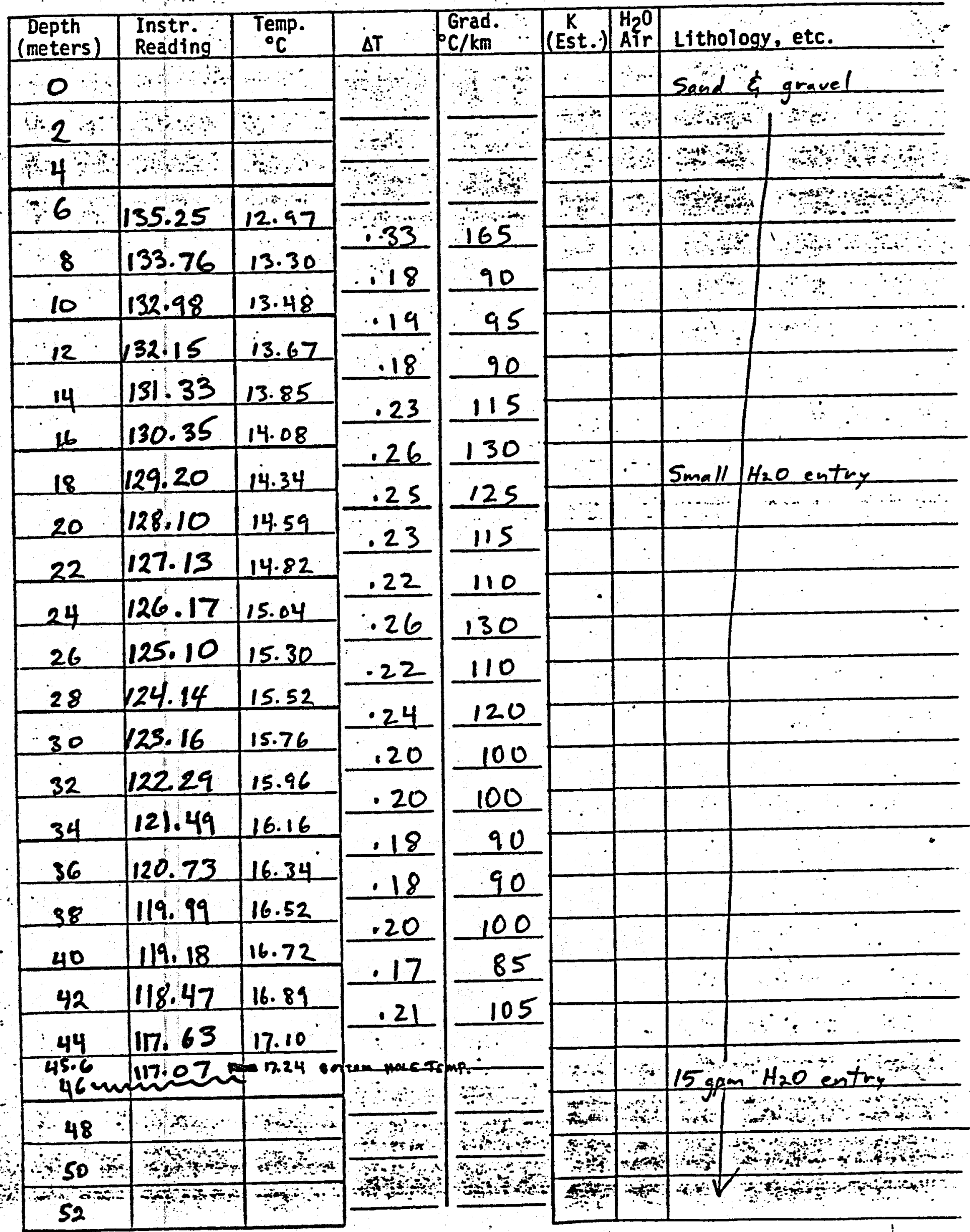




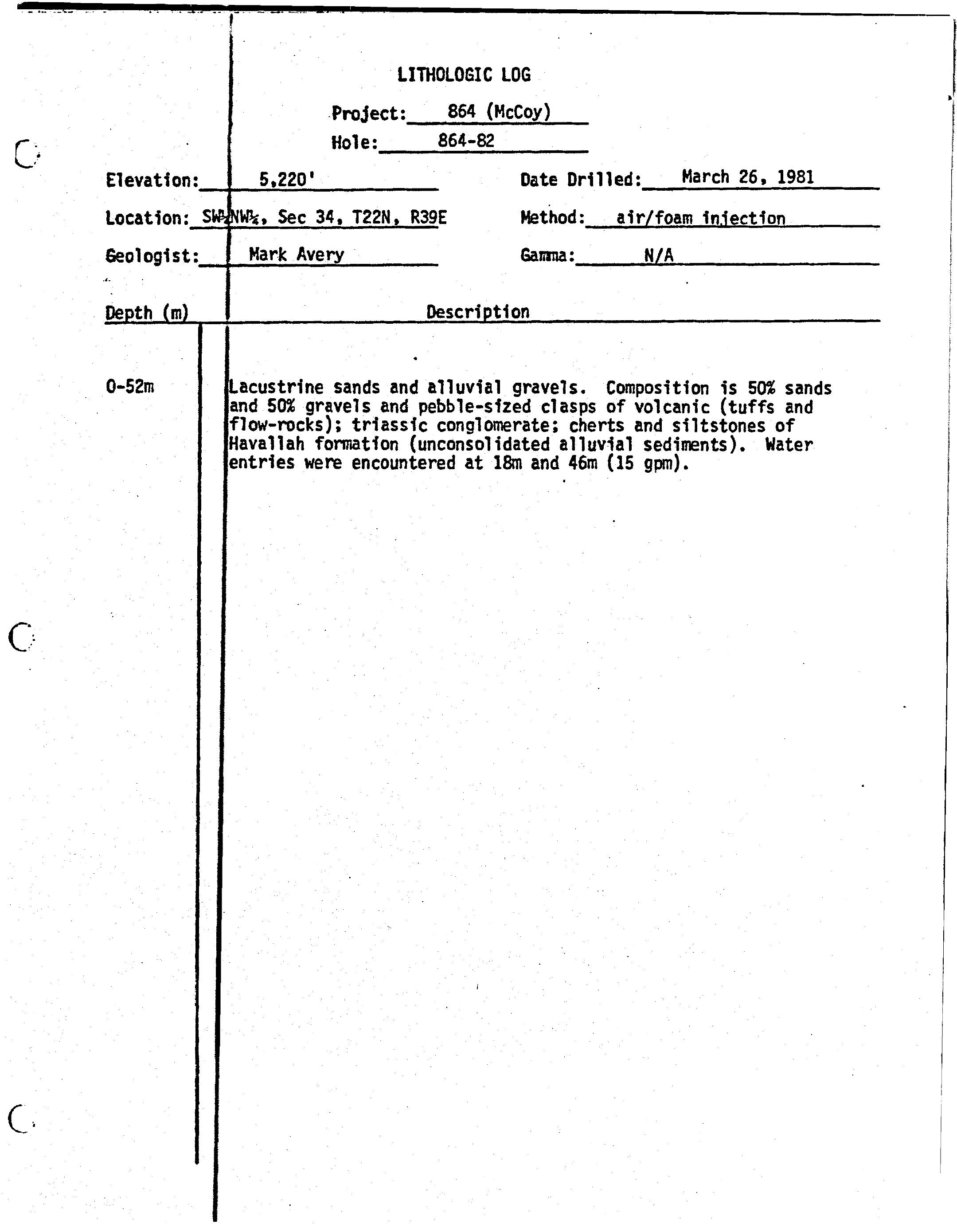




\section{$\therefore$ Property-Project DIC COY - 864 \\ $\Delta \mathrm{T}$ Well No. $864-88$ Map EquARDS CREE VALLEY scale $15^{\circ}$ State NEVAOA County CMrenill _ _ Instrument SAAFFED \& 46 Operator MAR AERY Depth Logged comments 2 n? \& fixal $\Delta T \log$ Date: Drilled o4/ 04/81 Logged $05 / 23 / 81$ Of SE of SW of SE of Sec2S T22N R $39 E$ Elevation $5430 \quad(\mathrm{ft})$}

\section{Date Logged}

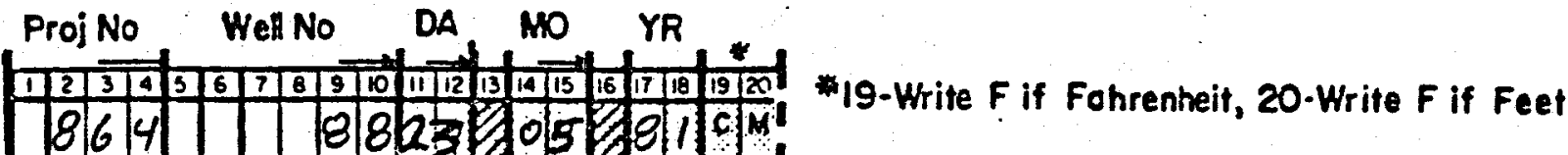

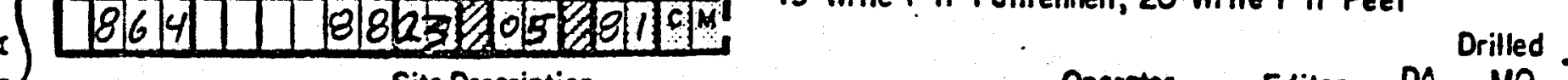

(ำ

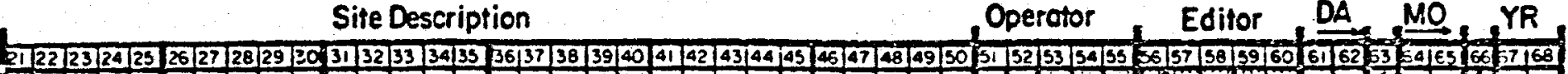

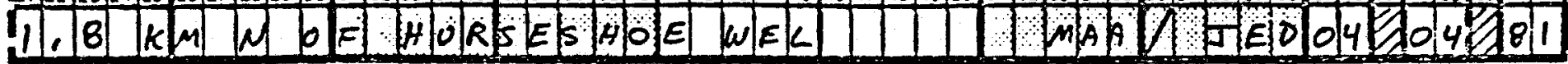
(Approx. locotion, woter well?, oil test?, etc).

Scoke Unit N Lot

Mop Location * *

IN MapSize WLong CM, (7.5,15.,60), Degree, Min Degree, Min * (21 22]23 24135

Segment $!=$ Depths

Stort
Conductivity

End $K$ $\Delta K$
- Best cond. $(-K)$

Downward extropolations

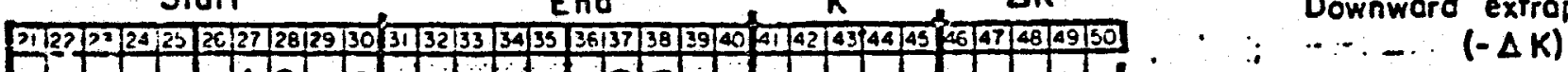

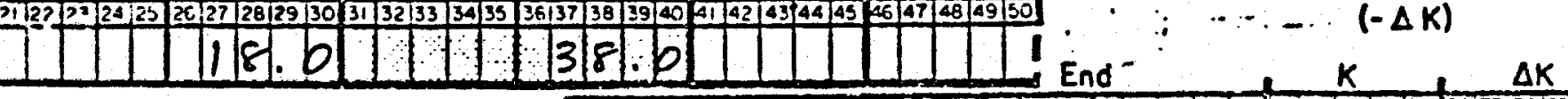

Segment 3

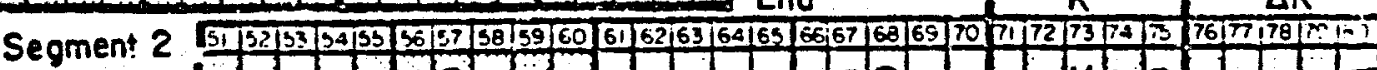

TIT Stort $\rightarrow 11 \backslash \backslash 1$ B, $b$ $788.20-4,0$

Segment 5

Segment 4

Tा

Segmeni 7

stort

fiziel

पाW $\square \square$

Segment 9

Segment 8 


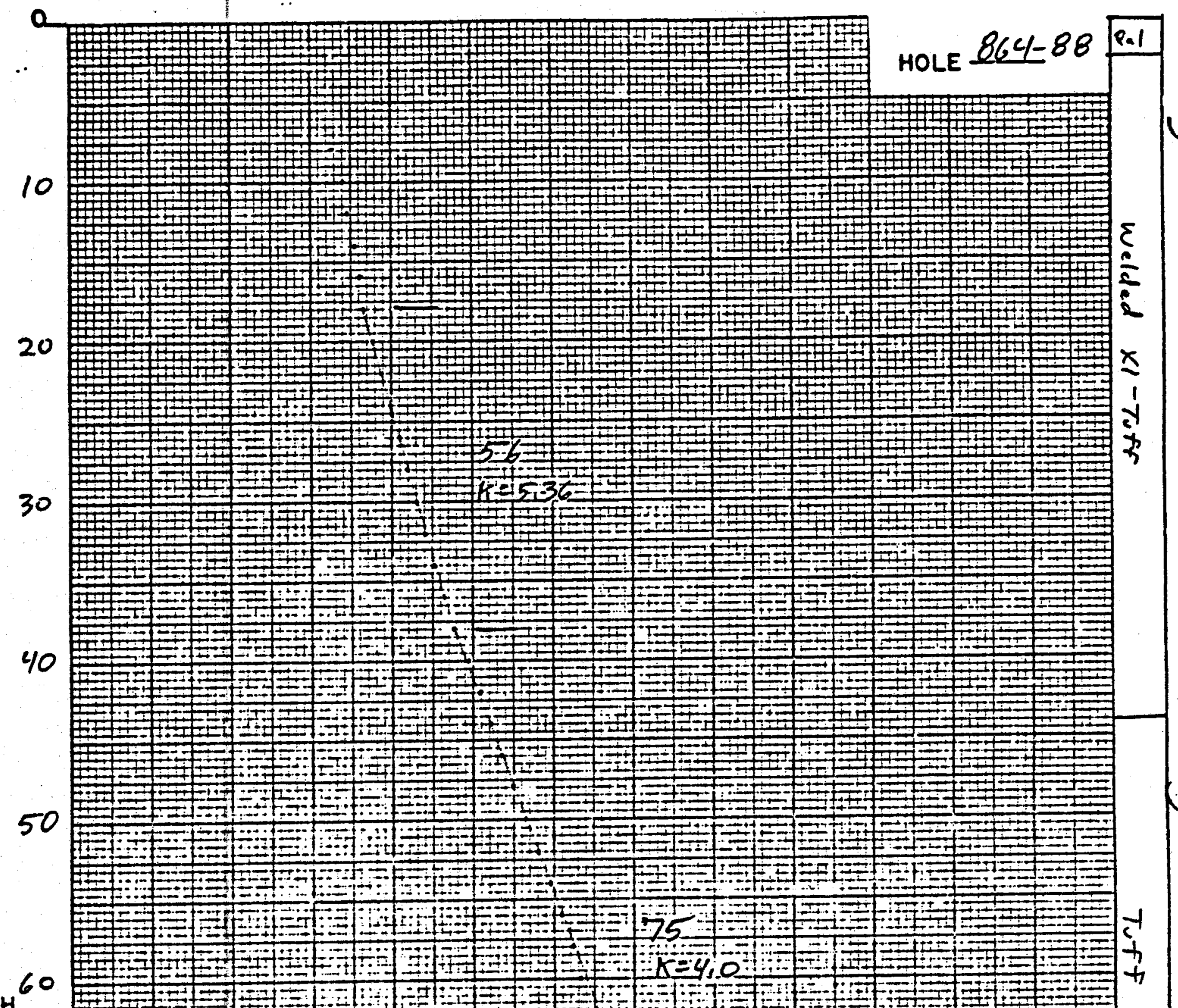

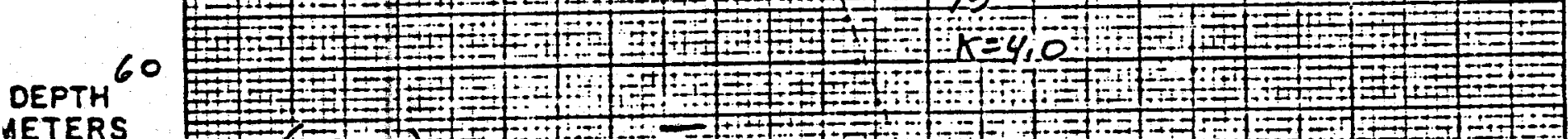

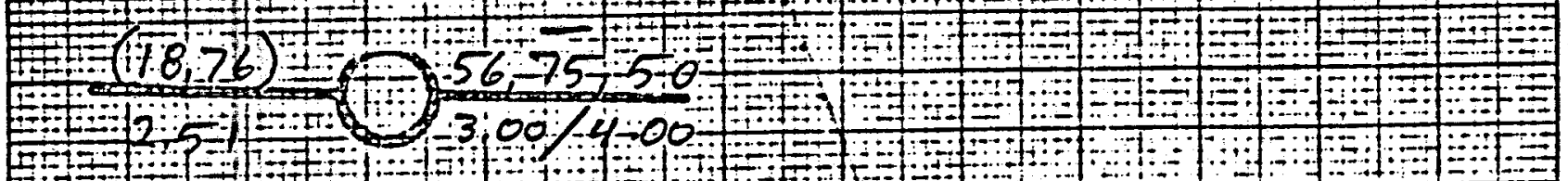

70

$\Rightarrow$ E

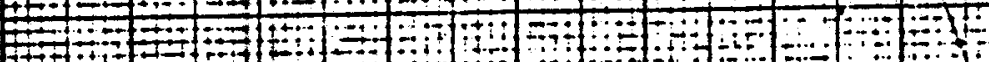

4 1 4 -

80

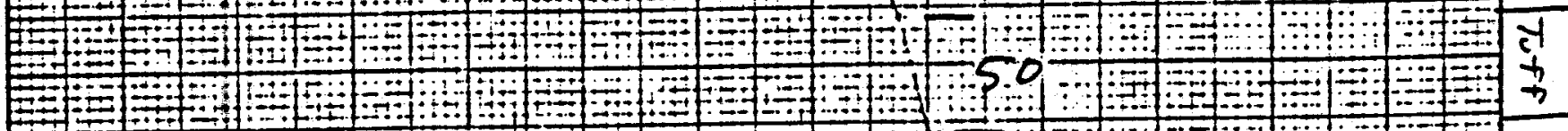

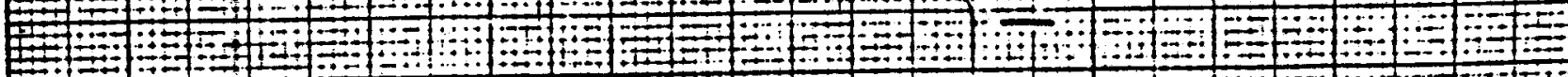
1 $=1$ a

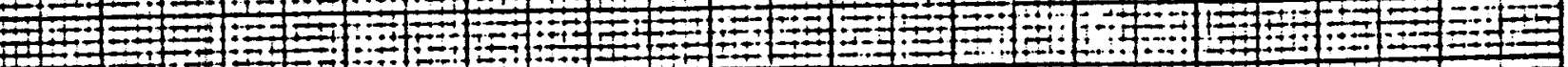

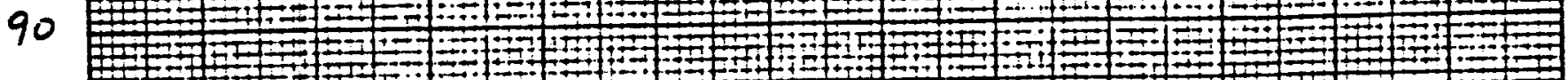

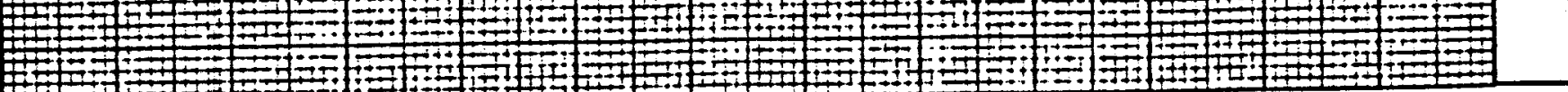

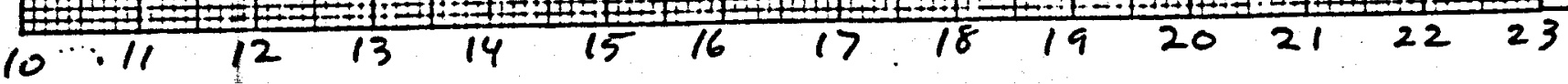


Date Logged: $05 / 23 / 81$

$\Delta T$ Well No. $864-88$

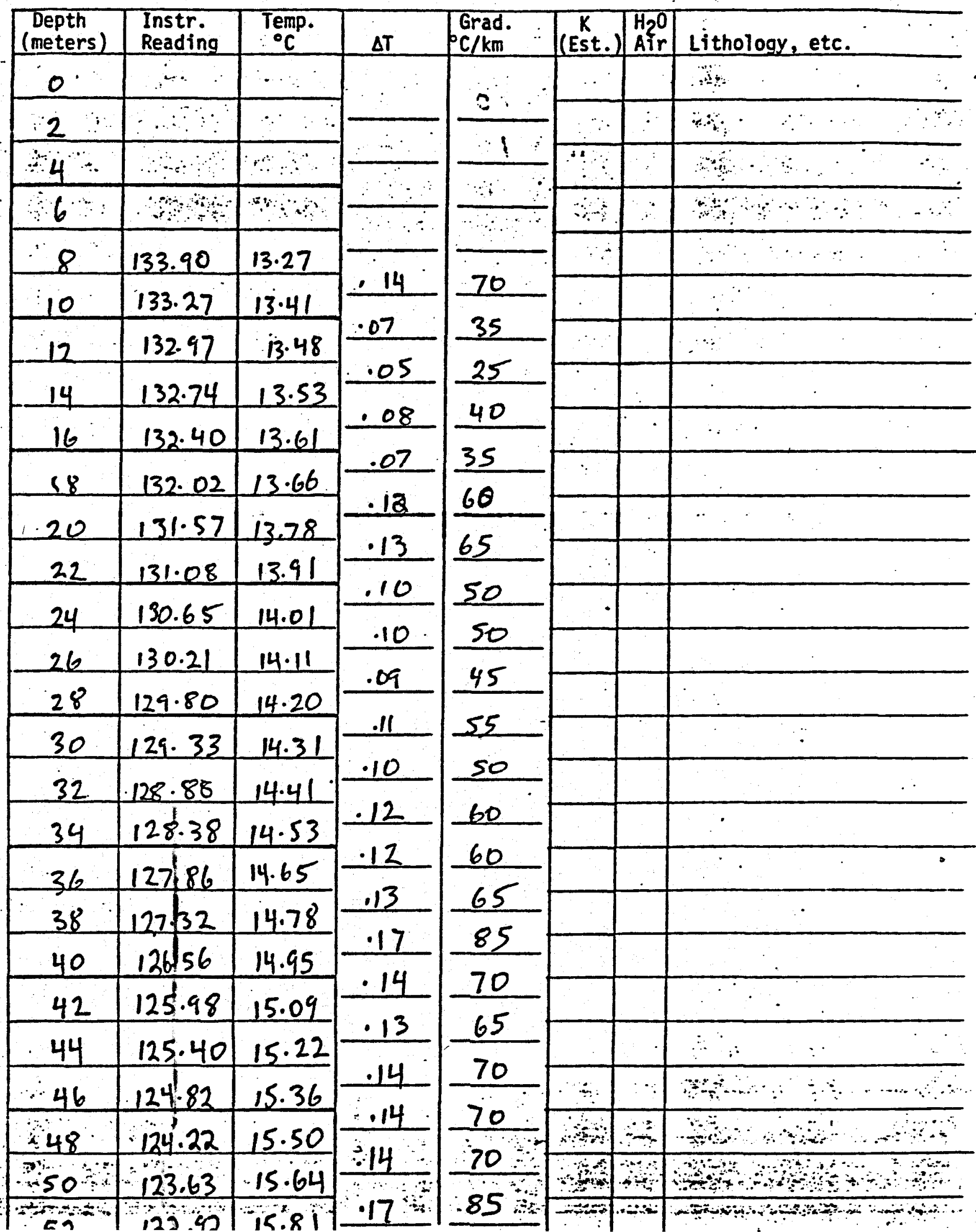


Project: Mccoy

Hole: $\quad 864-88$

Elevation: 5435

Location: SWSE 25 T22N R39E

Geologist: Deymonaz
Date Drilled: $\quad 4-4-81$

Method: rotary air

Depth (m) Description

$0-2$

2-44

$44-78$

Alluvium - It. reddish-brown to tan, sandy silt with subangular gravels of intermediate volcanics and minor limestones and cherts.

Gama:

Welded Crystal Tuff - primarily it. red with lessor mounts of it. gray, hard, 15-30\% phenocrysts (2-5mm) of feldspars (mostly altered to clays), smaller clear to milky anhedral quartz (5\%), and trace of biotite, and small magnetite. Minor limonitic staining and manganese coatings along small fractures. Some of the larger anhedral, white material altered to clays may be relic pumice fragments.

Tuff - it. pink to it. gray tuff altered to montmorillonite clays. Firm when dry, swells and crumbles when wet. 5-20\% small crystals of quartz (3-5\%) biotite, magnetite, and altered plagioclase. Up to $20 \%$ of sample consists of crystal tuffs from above, amount decreases with depth.

Tuff - 1t. pink to 1t. gray, firm to hard, $2-3 \%$ clear anhedral quartz phenocrysts, trace of magnetite up to $1 \mathrm{~mm}$, and biotite $1-2 \mathrm{~mm}$. Groundmass of fine granular tuffaceous material and altered feldspars. Limonitic staining common along small fractures and around some magnetite grains. Minor small (1-2mm) quartz filled veins. 
- AMAX EXPLORATION, INC.

TEMPERATURE/DEPTH LOG

C. Property-Project MC COY Depth Logged 96 meters MapepwPRDS CREEL Scale $15^{\prime}$ Date: Drilled $04 / 04 / 81$ Logged $05 / 23 / 81$ state NEV. countychureniLL of NW of SW of SW of Sec 31 T22UR $40 E$ Instrument SPAFTRD \& 46 Operator MAR ARPY Elevation 5400 ( $\frac{F 9}{\mathrm{~m}}$ comments 2 nd i final bog.

\section{Date Logged}

jUStIFY Proj No Well No DA MO YR
웅

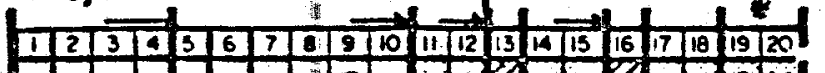

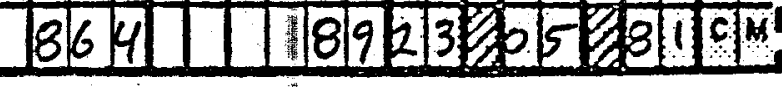
W-Write $F$ if Fohrenheit, $20 \cdot$ Write $F$ if Feet
Site Description
Operotor Editor DA MO MO YR

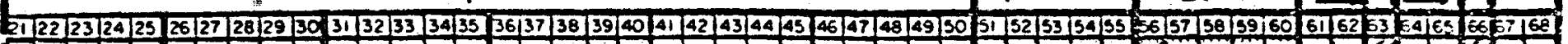

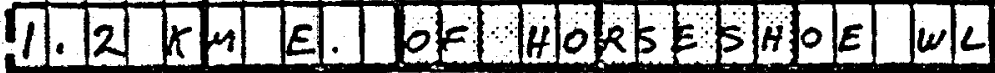

(Approx. locetion, woter wall!, oil test?, etc.)

0
0
0
0

Scoke Unit Mopstre NLot

Mop Location **

dM, $(7.5,15,60)$, Degree Min Degree Min

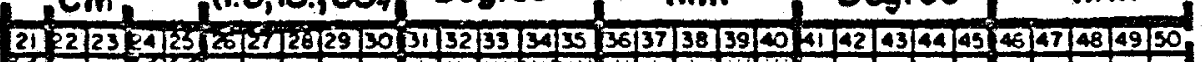

,

m.8. 15.03139 .330031117 .0145 .6

Use decimals

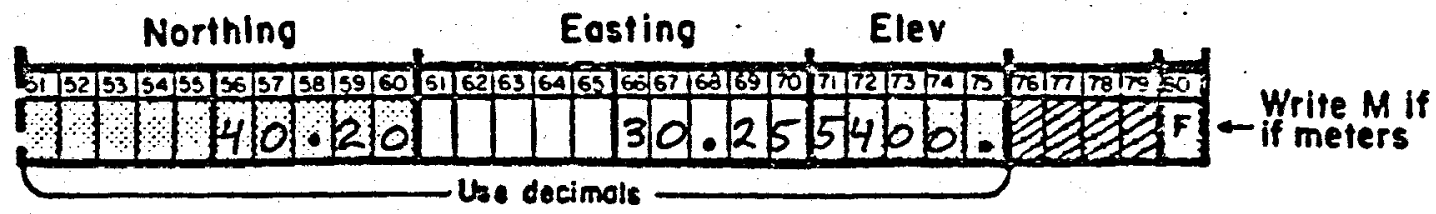

Segment $:=$ Depths

Stort
Conductivity

End $K, \Delta K$

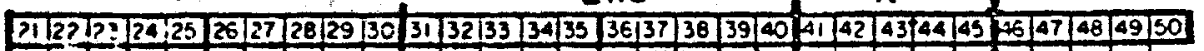

Mecaure from Sw

corner of mop ;exomp

AHS sheots moosure

from bottom center

degree mork $\left(W_{-}\right)(E, t)$

Elev

Best cond. $(-k)$

Downward extrapolations

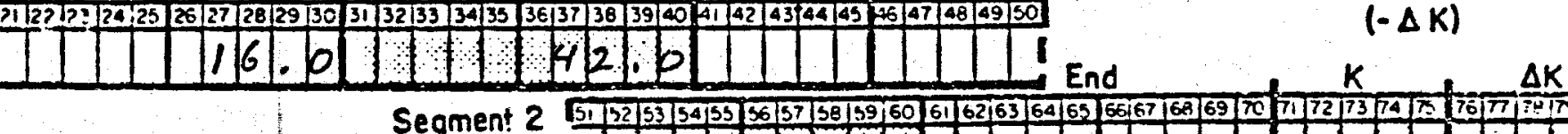

Segment 3

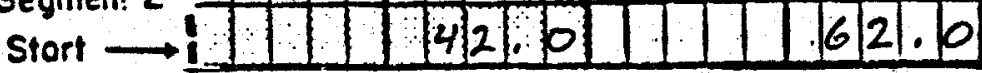

TIDI

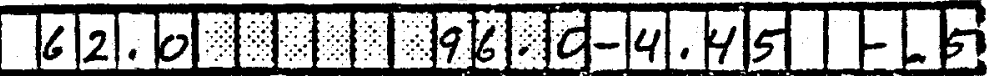

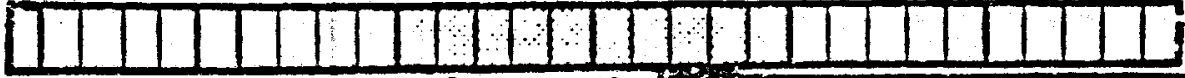

Segment 7

Segment 6

D.

Start $\rightarrow$

Segment 9

Segment 8
Start $\rightarrow$

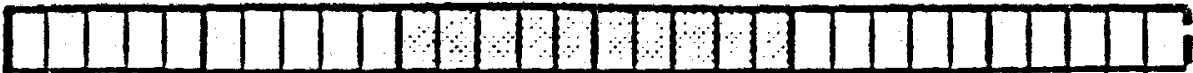

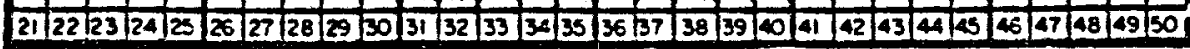

$\therefore \therefore$ Segment 1010060 
$+2$

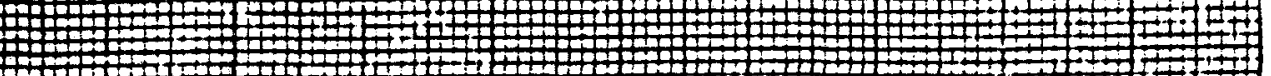

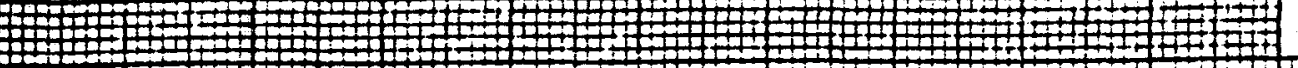

HOLE $864-89$

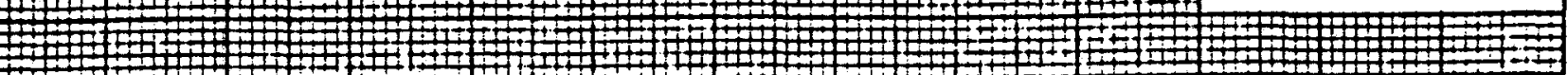
W

10

W W

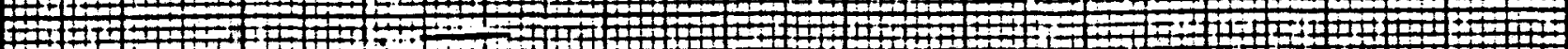

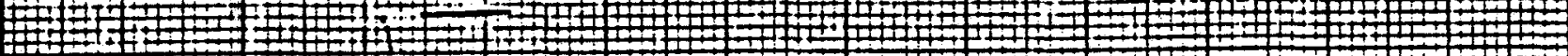

20

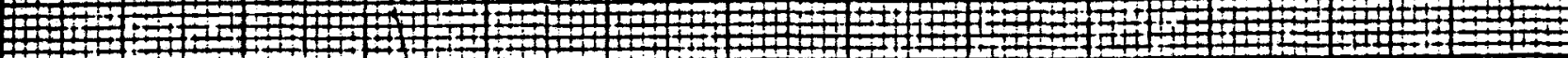

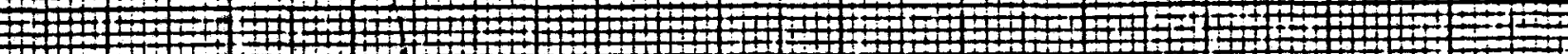

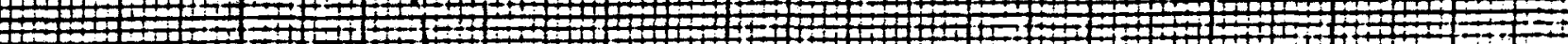

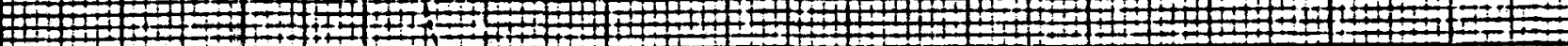

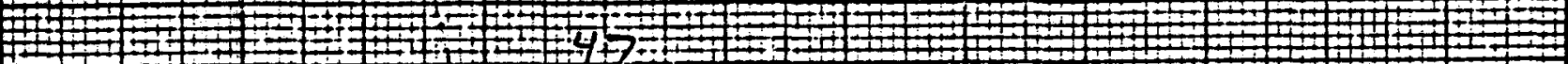

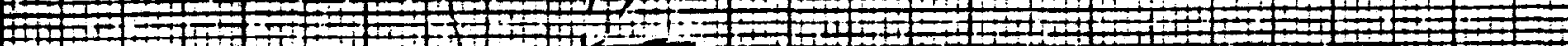

30

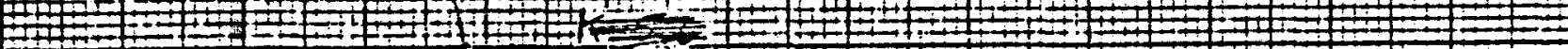

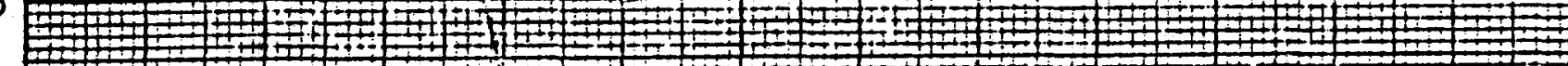

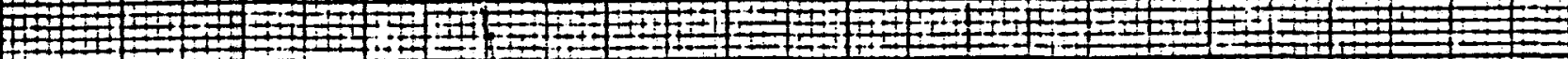

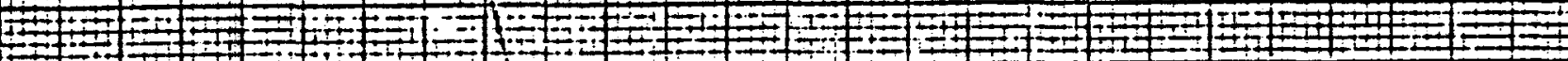

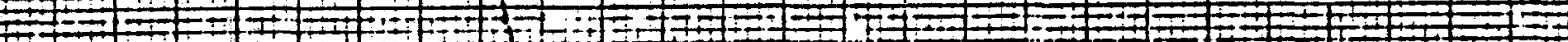

40

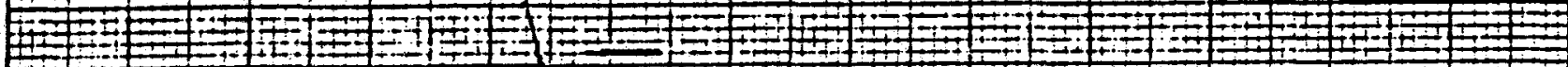

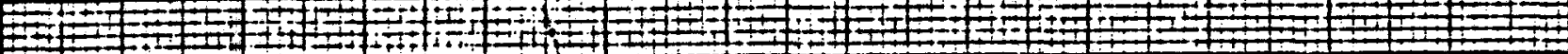

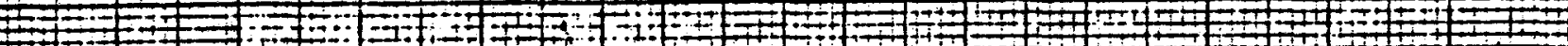

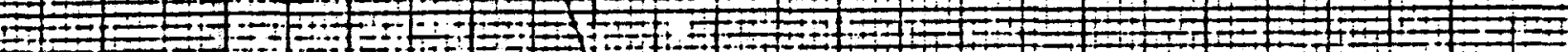

50

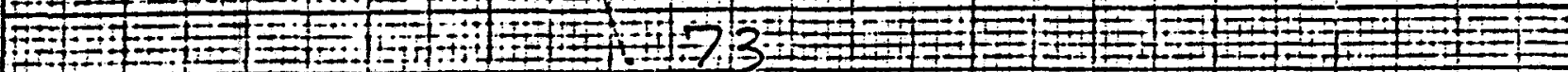
H.

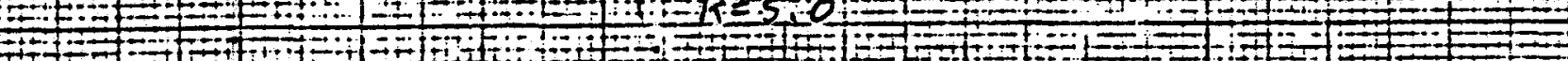

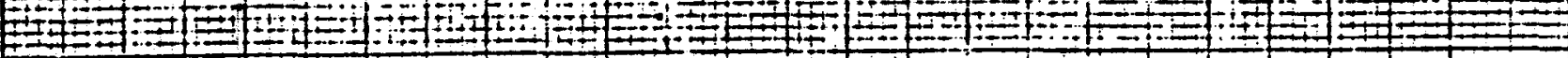

60 DEPTH

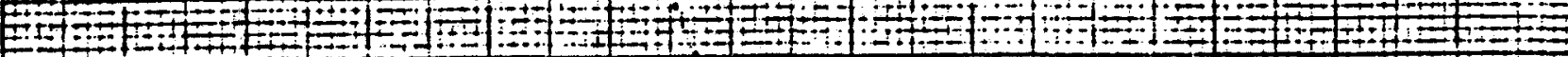

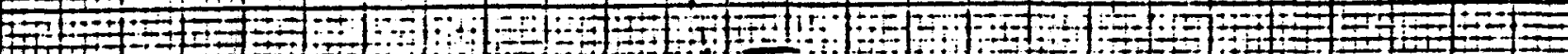

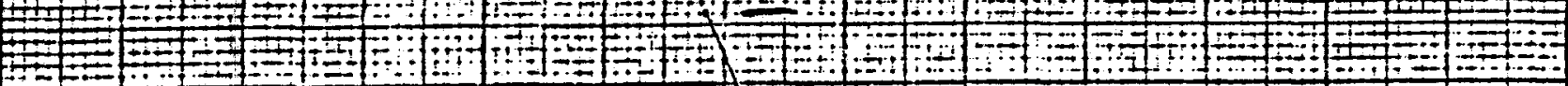
物

70

$+18 \div 6$

Fin: 3

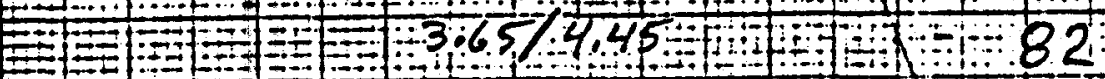

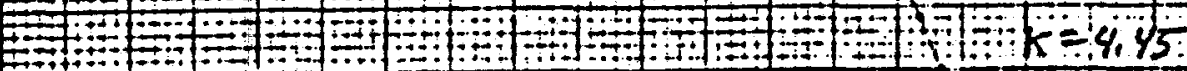

80

- 0 -...

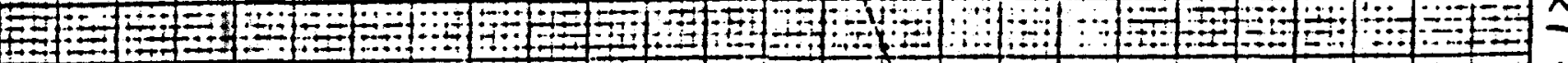

El

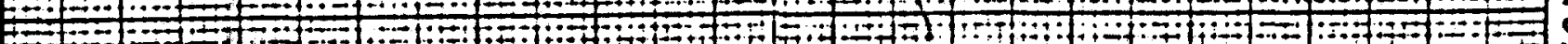

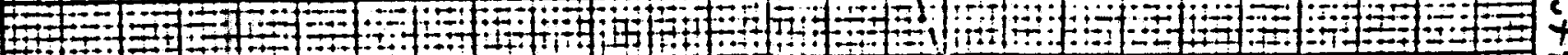

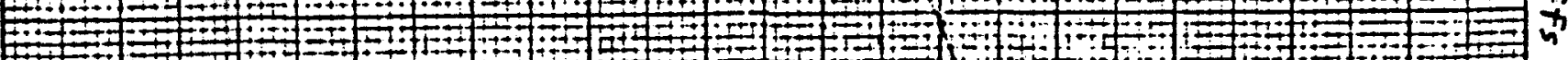

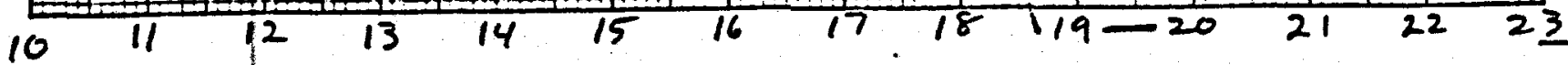


Date Logged: $05 / 23 / 81$

$\Delta$ T Well No. $864-89$

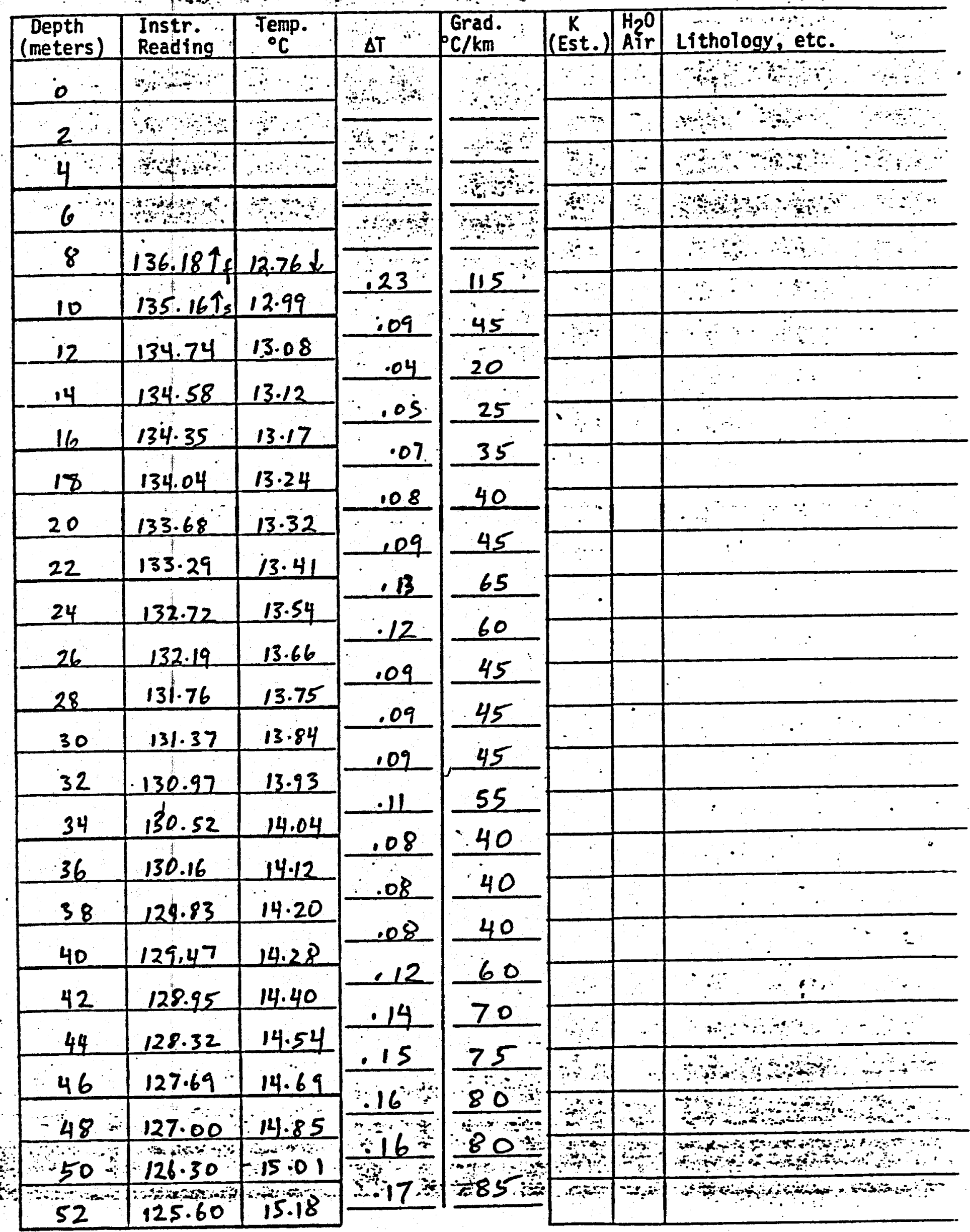


Project: McCoy

Hole:

$864-89$

Elevation: 5400

Location: SWSW 31 T22N R4OE

Geologist: Deymonaz
Date Drilled: 4-4-81

Method: rotary air

Depth (m) Description

0-49 Alluvium - tan, sandy silt with small angular to subangular gravels of volcanics and minor cherts and limestones. Too damp to drill dry at $9 \mathrm{~m}$. Predominantly grave is up to $10 \mathrm{~cm}$ in upper $8 \mathrm{~m}$.

Welded Crystal Tuff - pink, hard, brittle, fine tuffaceous to aphanitic groundmass with $10-20 \%$ phenocrysts of biotite (1-3mm), clear anhedral quartz (1-3mm), feldspars (mostly altered) and trace of magnetite and hornblende. Considerable oxidation of magnetite and some biotite, and red iron staining along small fractures. Appears to be pervasively fractured. $20-30 \%$ of sample consists of uphole sluff.

76-84 Crystal Tuff - as above, except poorly, or non-weided, predominantly $1 t$. gray to $1 t$. pink.

84-95 Crystal Tuff - non-welded, soft tuffaceous matrix washes out of cuttings leaving anhedral clear quartz, biotite, feldspars and lithic fragments. 


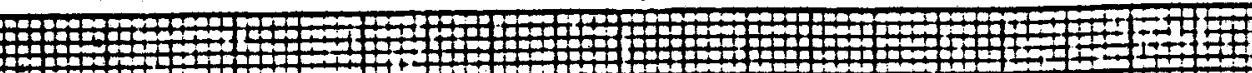

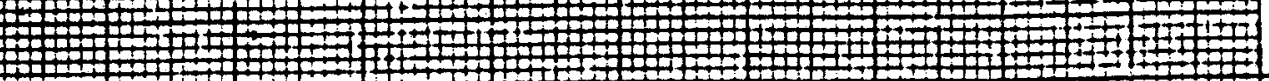

10

20

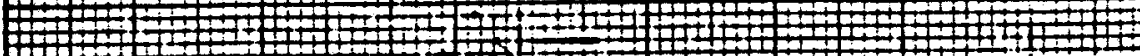

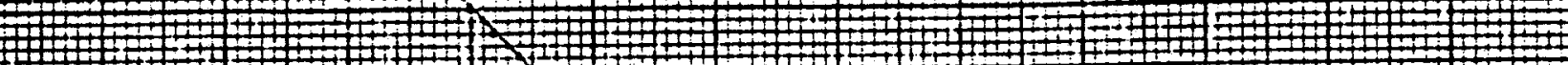

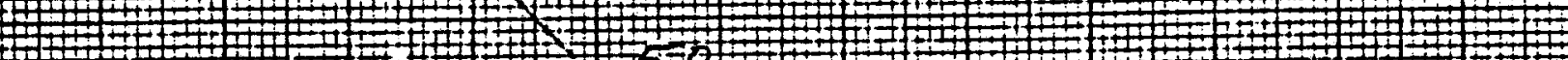

30

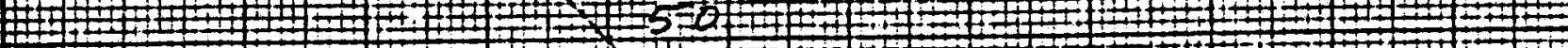
(7)

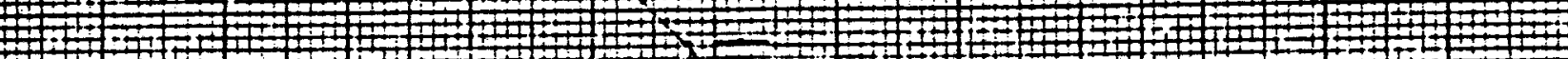

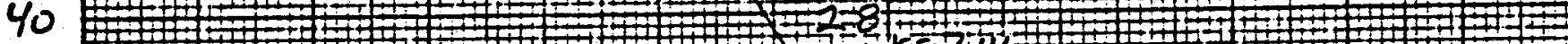

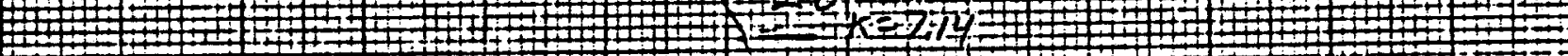

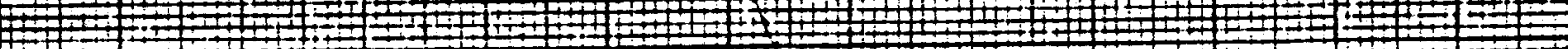

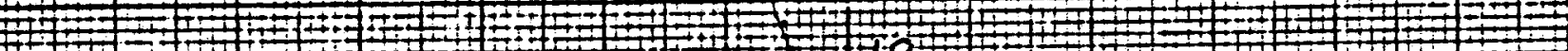

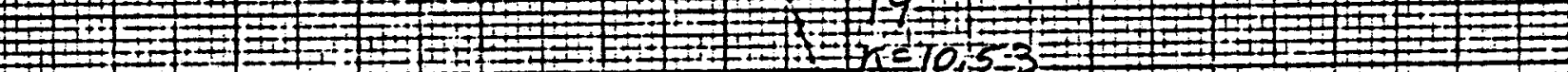

60

70

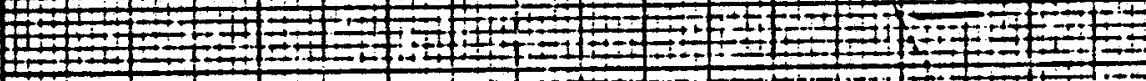
$112+1$

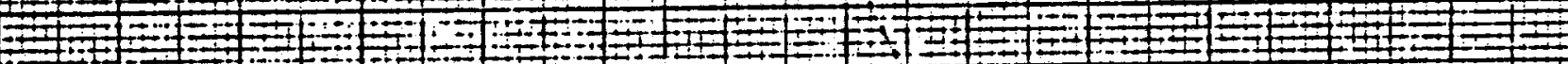

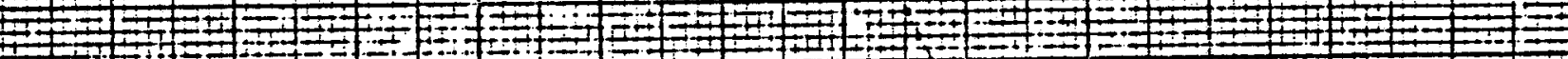

80

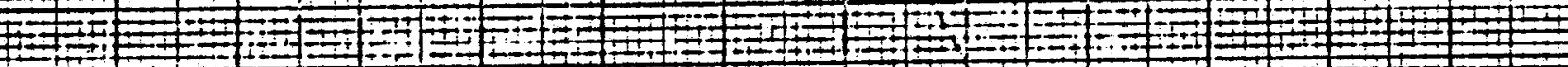

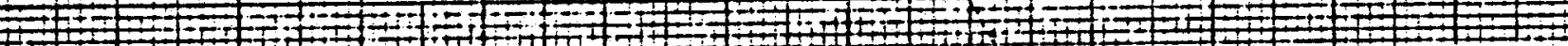

90

100

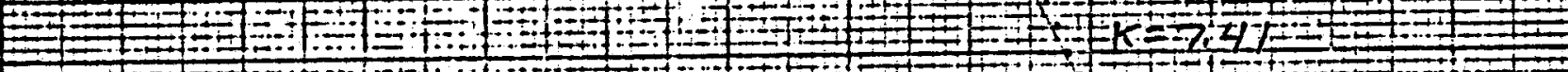

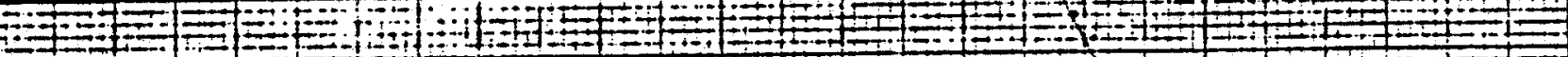

110

120 I

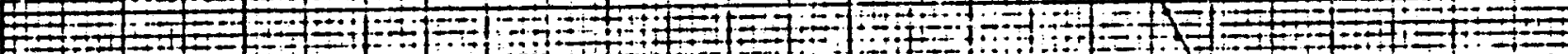
DEPTH AETERS

130

140

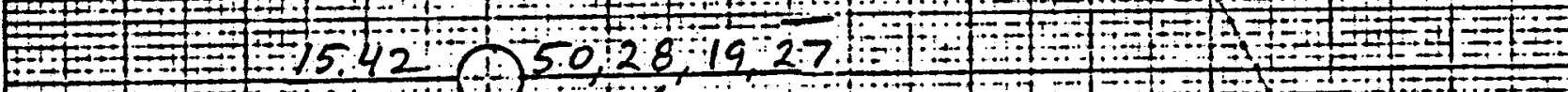
$=10=26.940 \% 7.4$ $7=0$

$7 \div$

\section{$+1$}

150

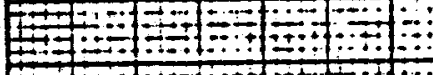

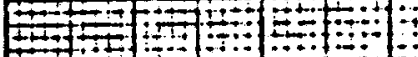

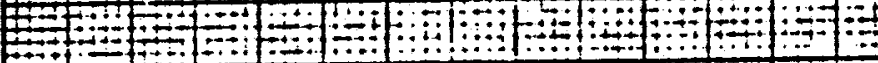

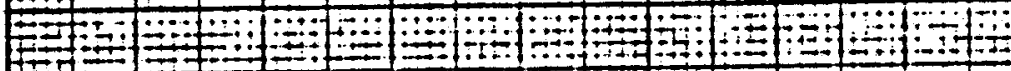

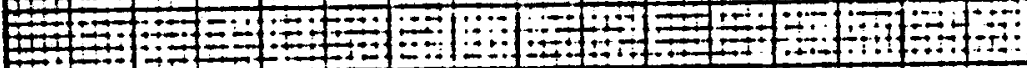

:


Sate Logged: $05 / 23 / 81$

$\Delta T$ Well No. $864-90$

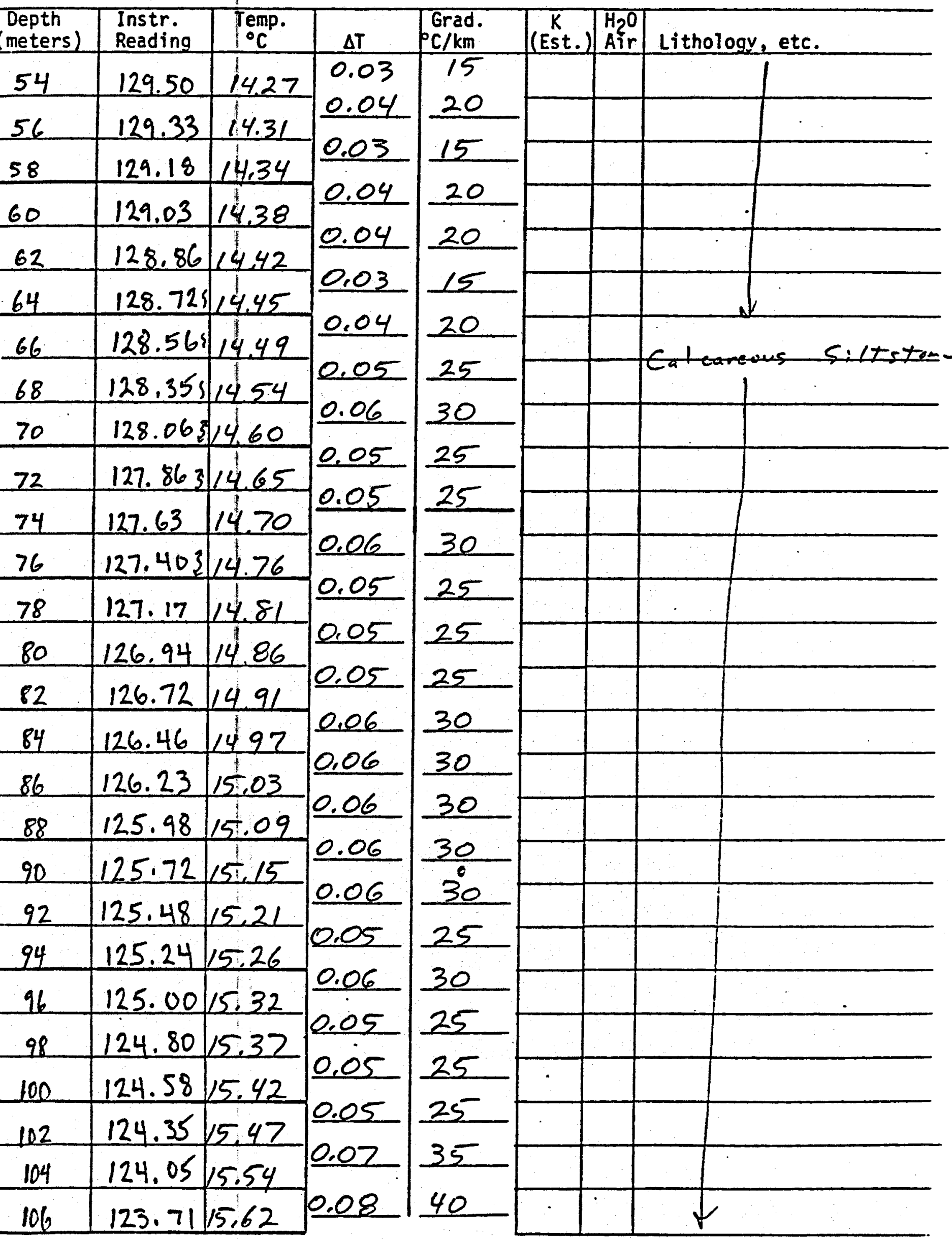


Date Logged: $05 / 23 / 81$

$\Delta T$ Well No. $864-90$

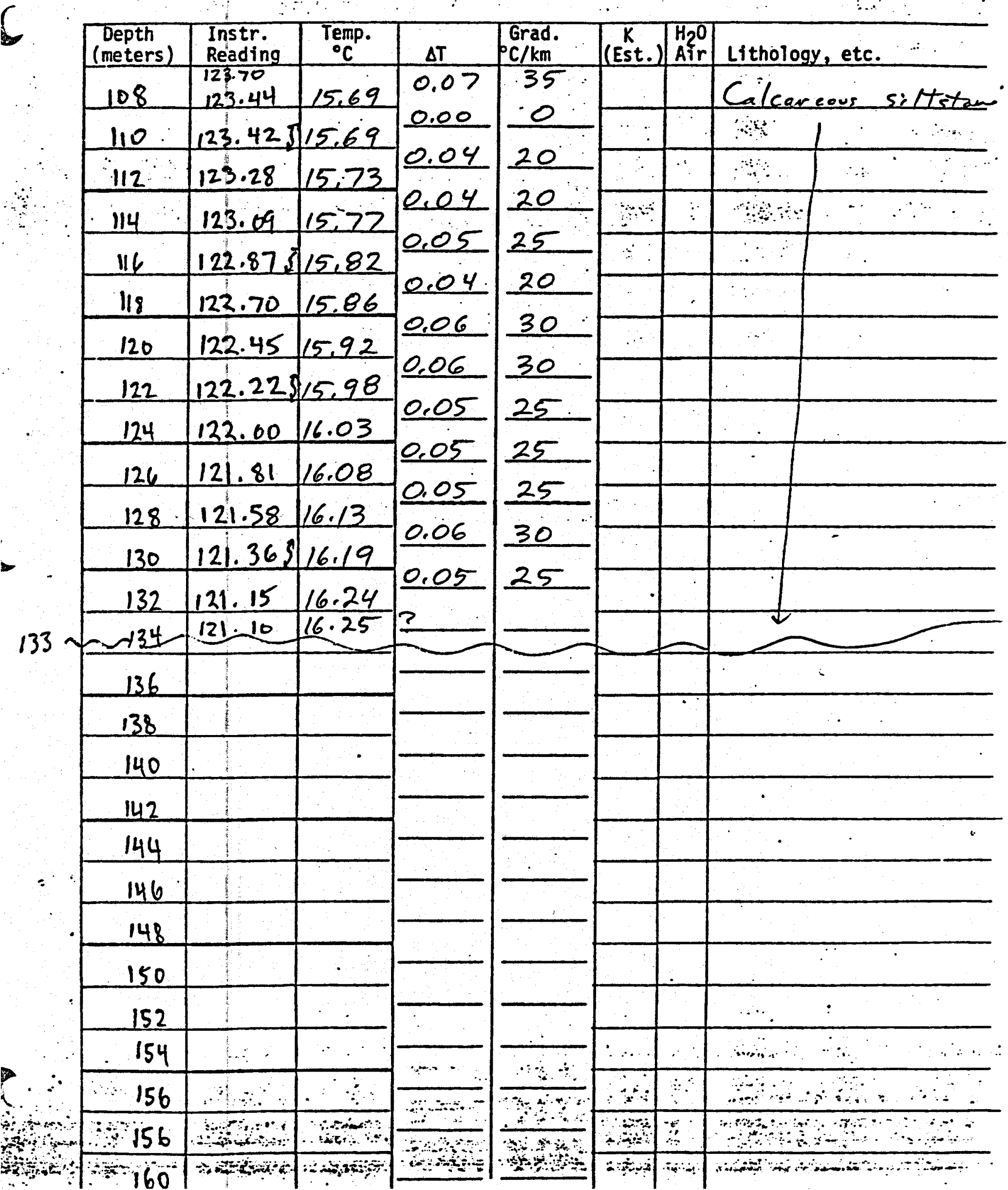


Project: McCoy

Hole: $864-90$

Elevation: 5720

Location: NWNW 32 T22N R4OE

Geologist: Deymonaz
Date Drilled: 3-27-81

Method: rotary air
Depth (m)

$0-9$

9- 15

$15-25$

$25-28$

28- 34

34- 67

$67-137$

Description

Alluvium - med-brown, sandy silt with subrounded to subangular gravels of latitic volcanics, siltstones, and limestones.

Latite Tuff - red to 1t.-gray, argillized and less commonly silicified. 5-10\% phenocrysts of clear tabular sanidine, squarish clear to milky k-spar, and minor biotite and quartz in tuffaceous matrix. Trace of small 1ithic fragments of volcanic rock and black siltstone. Some samples contain sufficient quartz to be classified as rhyolite.

Crystal-Lithic Tuff - white, firm to hard, 5-15\% xis of clear anhedral quartz (much of quartz has pale pink hue) 2-5mm, fresh appearing black to green chloritized biotite, $0.5-2$. Omm, and small rounded to subangular dk. gray to $1 t$. gray lith fragments of volcanics and black siltstones, in mottled white to pale greenish aphanitic groundmass. Minor small clear quartz filled fractures. White mottled appearance due to pseudomorphs of feldspars and/or altered pumice fragments.

Virtrophyre - black, glassy, with 50-75\% large phenocrysts $(2-5 \mathrm{~mm})$ of clear anhedral quartz, black euhedral biotite and clear to white fresh to altered feldspars in black glassy groundmass. Possibly base of above unit.

X1-Tuff - It.-med-gray, soft argillized tuffs. 5-10\% xis of quartz and altered biotite and feldspars. 2-5\% small aphanitic lithic fragments.

Chert (Fanglomerate?) - buff to 1t. greenish-gray and pale red, finely granular chert. Color varies considerably in each sample. Some rounded weathered surfaces observed. May be fairly well indurated fanglomerate (penetration 80-100 ft/hr with mill tooth bit and air). Cherts are comonly fractured and iron-stained, minor thin manganese - deposits along fractures.

Calcareous Siltstone - black, effervescence vigorously in $\mathrm{HCl}$. Minor small veins $(1-3 \mathrm{~mm})$ of clear to white calcite. Trace of small $(0.1-0.5 \mathrm{~mm})$ dissiminated pyrite. Firm to hard, drills easily with mill tooth bit $(60-80 \mathrm{ft} / \mathrm{hr})$ and commonly breaks along poorly defined laminations. 


\section{AMAX EXPLORATION, INC.}

TEMPERATURE/DEPTH LOG

$\Delta \mathrm{T}$ พell No. $864-92$

Property-Project MC COY:-864 Depth Logged 83.3 acters Map M. Alry NW scale 7.5 Date: Drilled $4 / 6 / 81$ Logged $05 / 28 / 81$

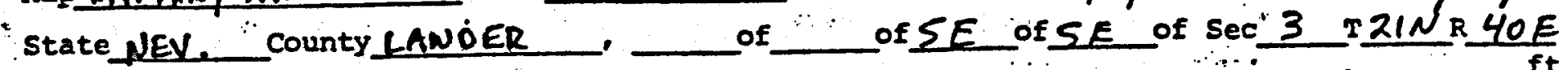

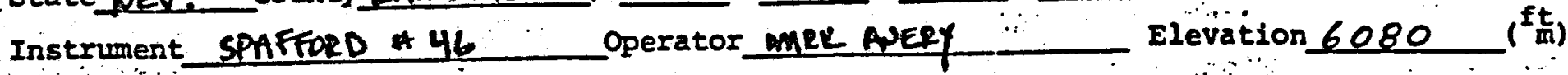
Comments SECOND LOGGING OF MUIS OT HaE.

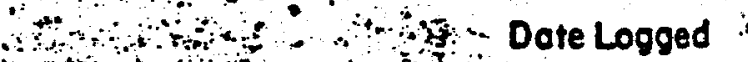

JUSTIFY Proj No Well No DA MO YR

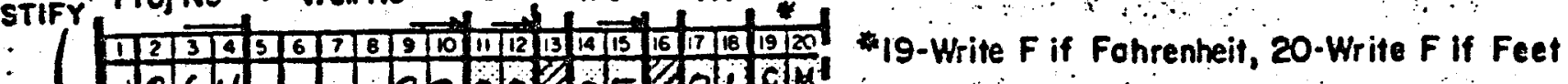

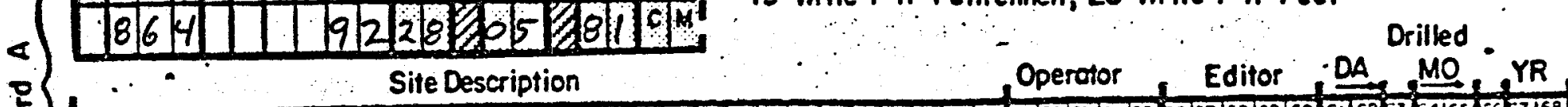

总

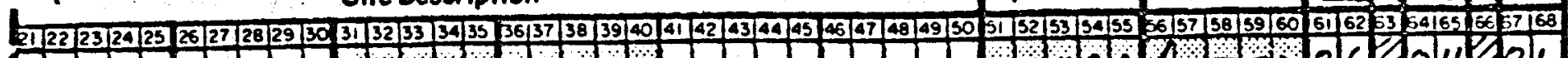

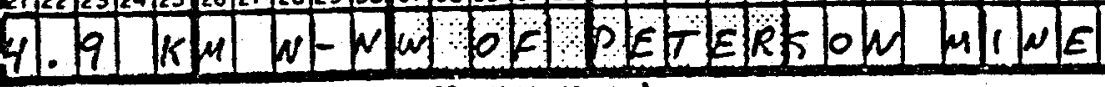

(Approx, locetion, wofer welli, oil testl, etc)

- Scal Unit Mopstze NLat. MOP Locotion WLong CM $(7.5,15,160)$, Dogree, Min Degree, Min. ** Meosurg from Sw

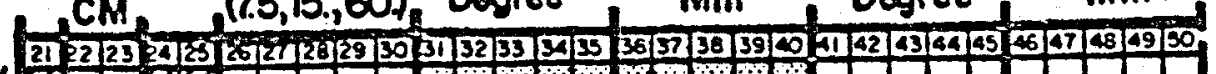
0
0
0
0
0
0
0

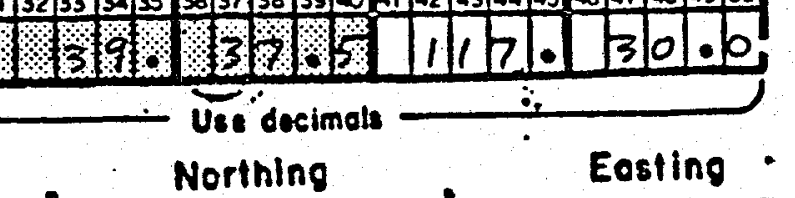
corns of mopiercopt irom bortom conter from oortom conter

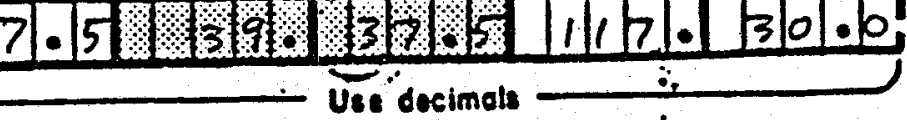

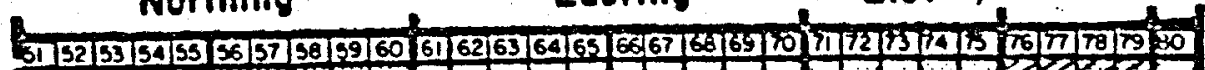

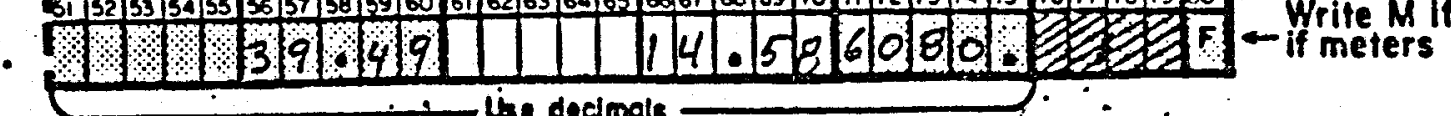

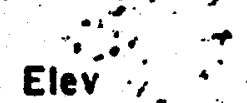

Segment $!=$ Depths

Start

Conductivity

Dest cond. $(-K)$.

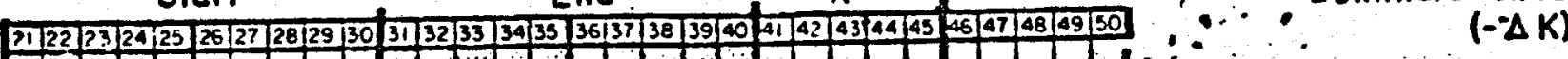

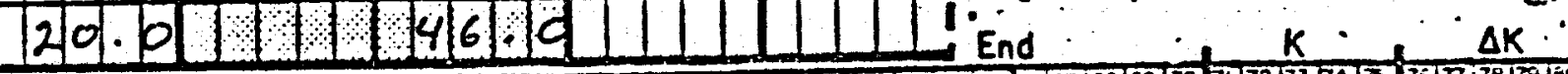

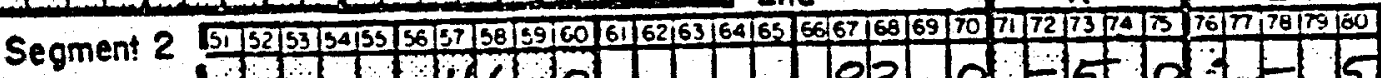

1 Segment 3

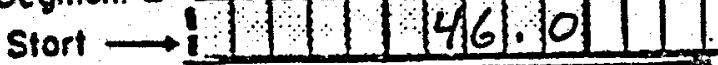

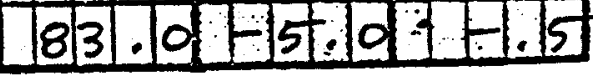

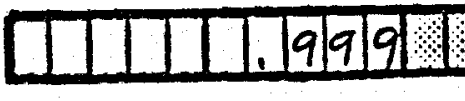

Segment 5

Segment 4

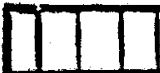

Stort

Segment 7

Segment 6

Thm

Siont

$\cdots$

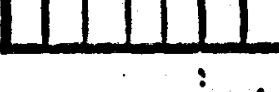




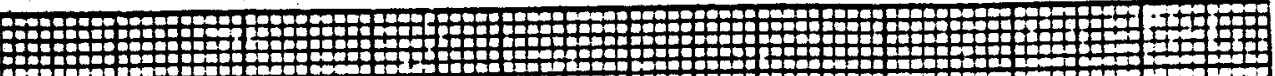
W

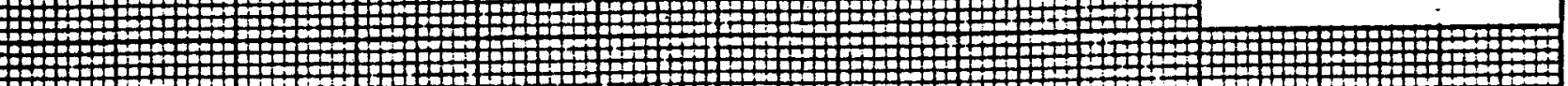

10

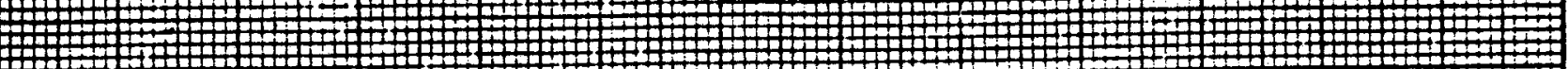

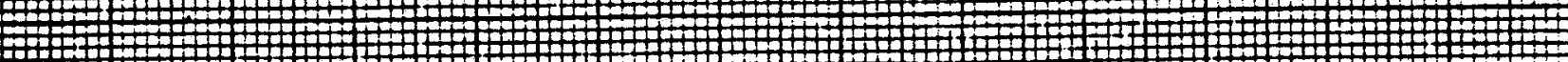

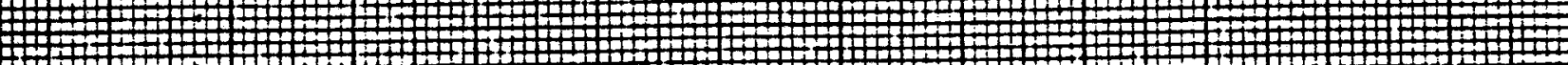

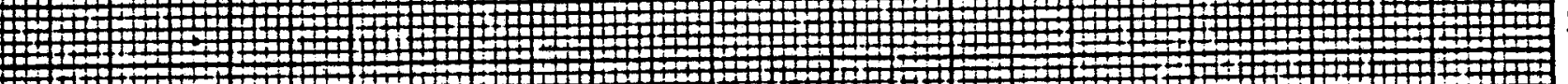

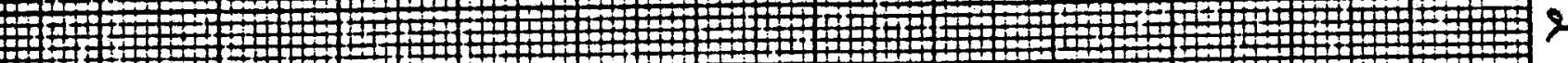

20

30

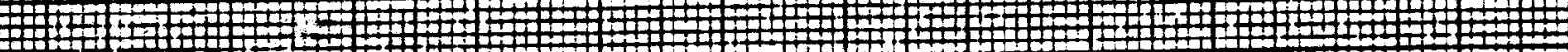

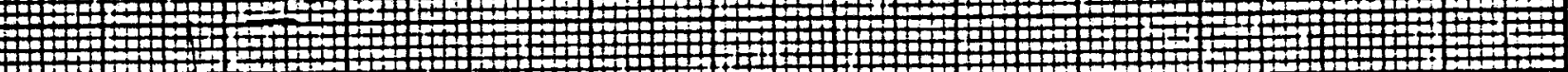

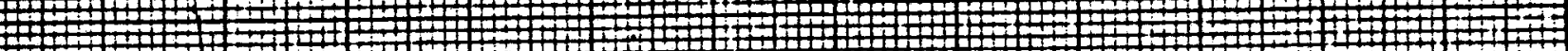

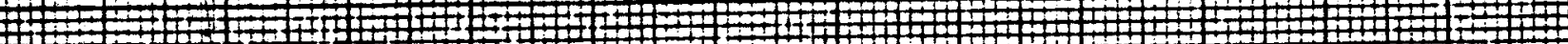

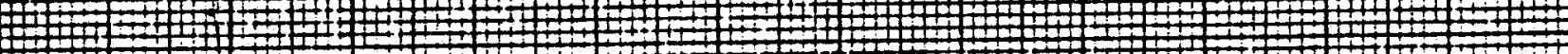

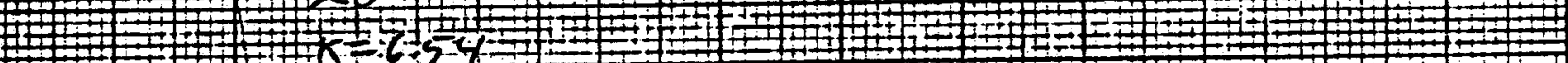

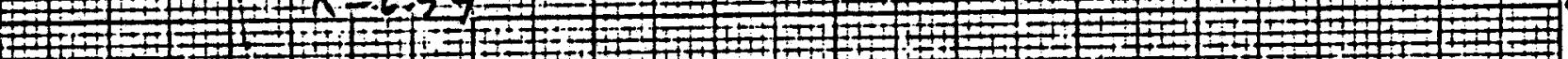

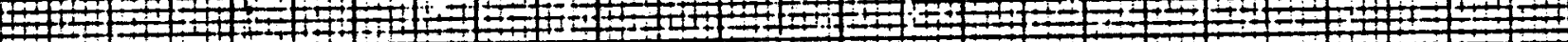

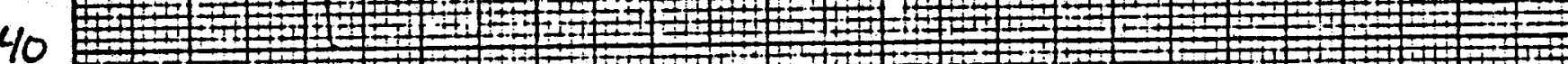

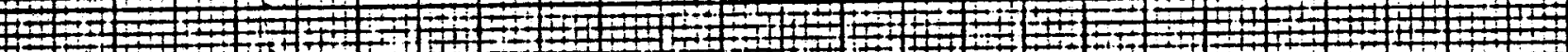

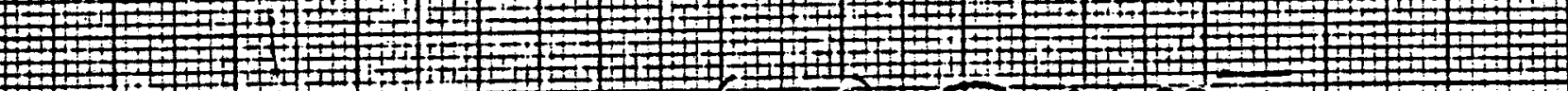

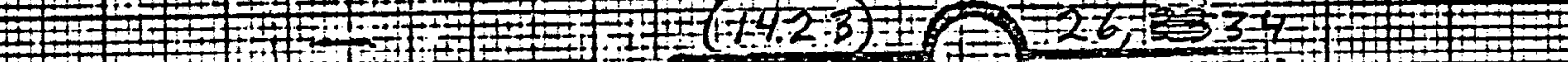

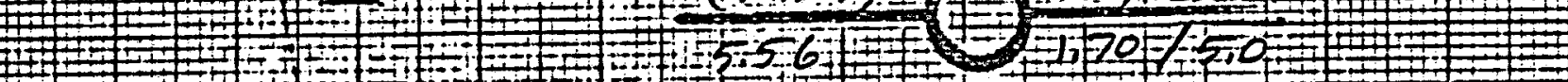

50

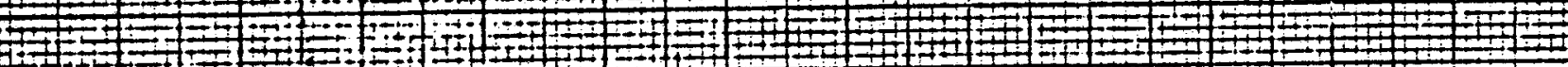

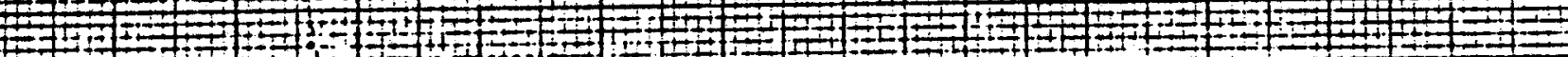

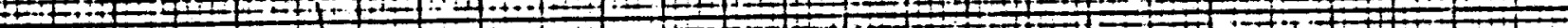

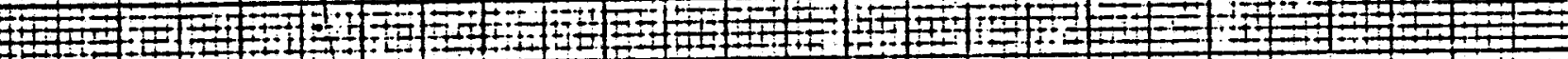

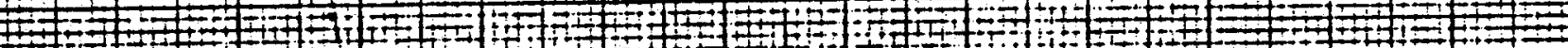

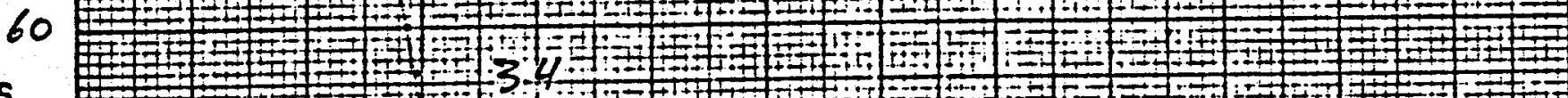
DEPTH

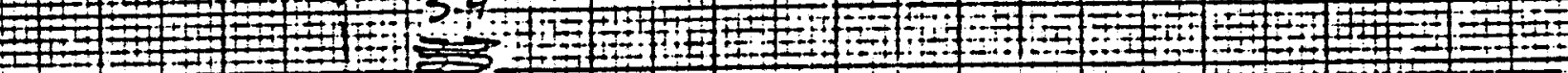

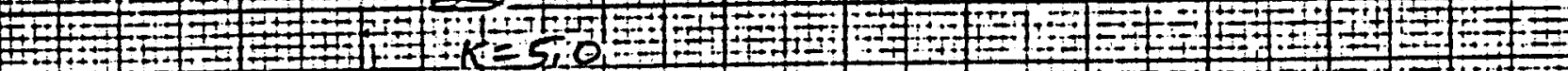
4 of

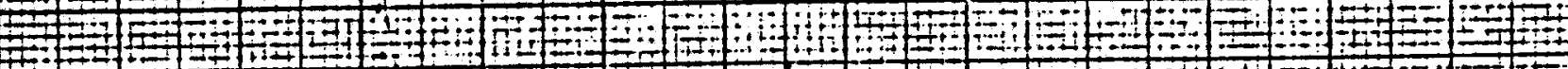

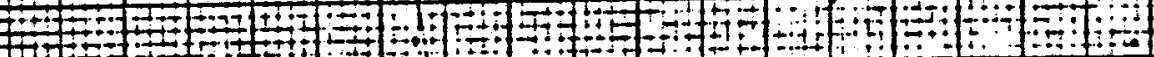

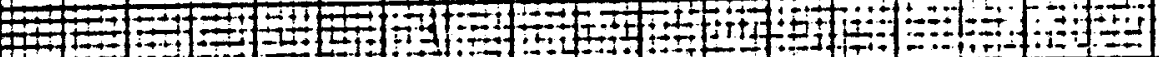

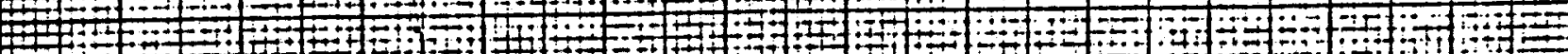

80

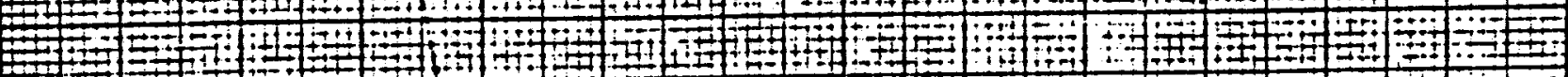

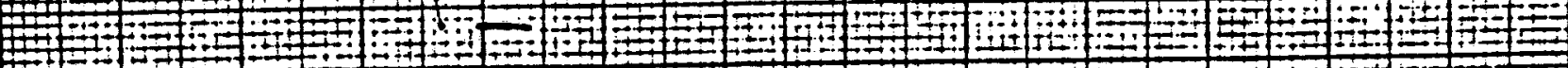

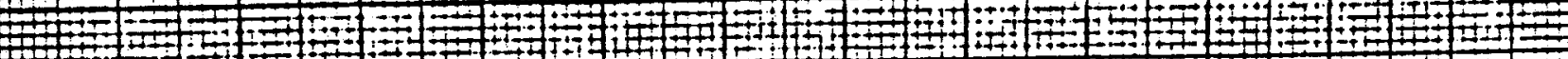

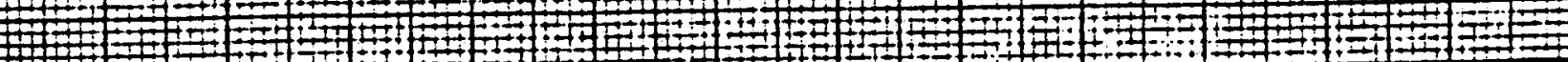

90

-

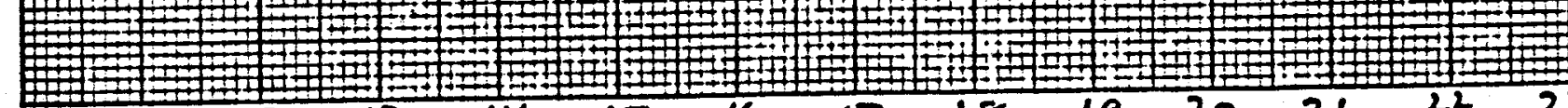

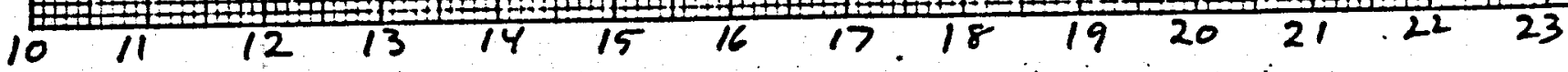


Dste Logged: $05 / 28 / 81$

$\Delta T$ Well No.864-92

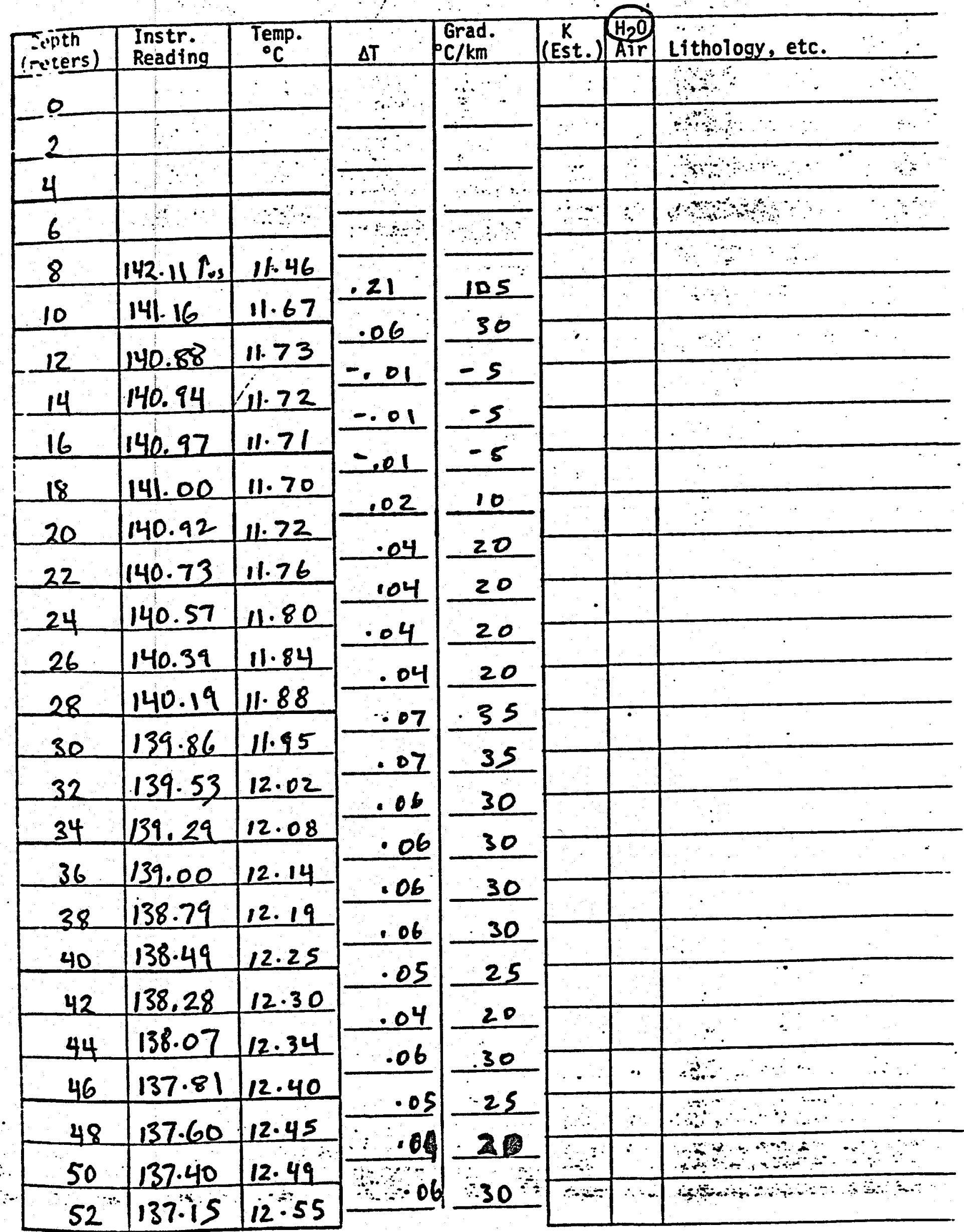


late Logged: $05 / 28 / 81$

$\Delta T$ Well No. $864-92$

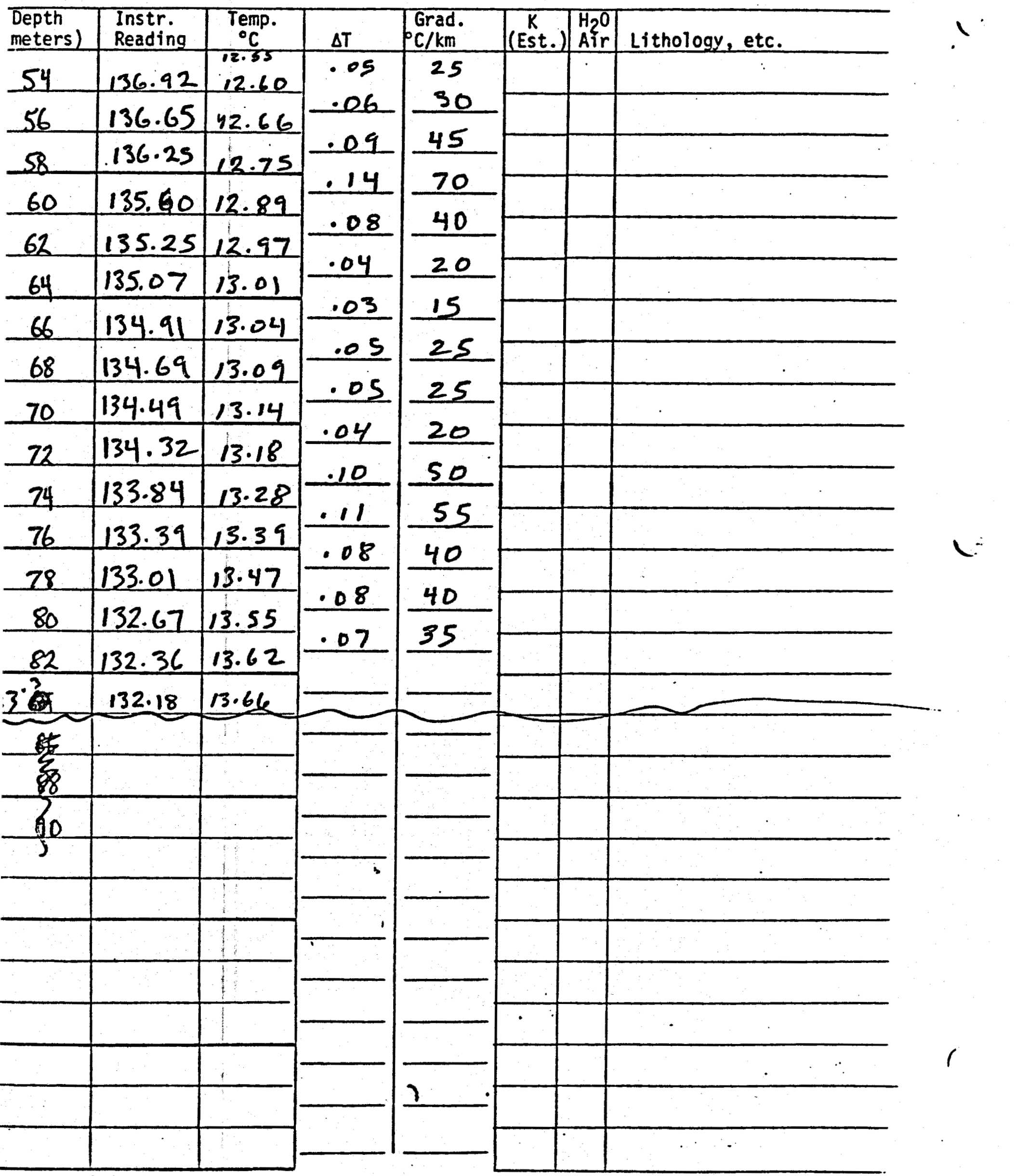




\section{LITHOLOGIC LOG}

Project: McCoy

Hole: $\quad 864-92$

Elevation: 6080

Location: SESE 3 T21N R4OE

Geologist: Deymonaz
Date Drilled: $\quad 4-6-81$

Method: rotary air

Depth (m) Description

0-30 Alluvium - tan, sandy-silt with angular to subangular gravels of chert, volcanics and limestone.

$30-46$

Fanglomerate - tan to red cherts with considerable variation within each sample, much iron-staining along fractures. 5-20\% fine siliceous sandstones. 10-50\% of sample volcanics and cherts, probably from upper $30 \mathrm{~m}$ of hole. Increasing amounts of tuffs below $40 \mathrm{~m}$.

46-82 Tuff - reddish-brown, firm to hard, matrix material argillic alteration to montmorillonite clays. 20-25\% small $(0.5-1.0 \mathrm{~mm}) \times 1 \mathrm{~s}$ of white to clear tabular plagioclase altered to clays, and an undetermined amount of small quartz grains. Trace of large biotite phenocrysts and small mangnetite. Manganese deposition on some small tight fractures. Tuff increasing in sample from below $46 \mathrm{~m}$ to $61 \mathrm{~m}$ where it comprises about $80 \%$ of sample. 



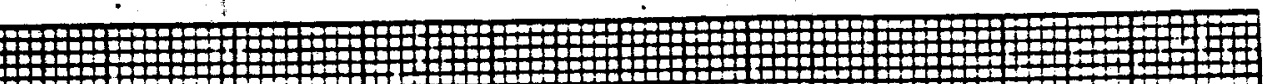

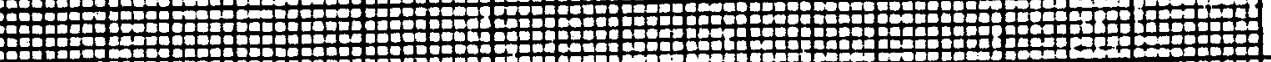

\section{HOLE $864-93$}

10

20

30

I

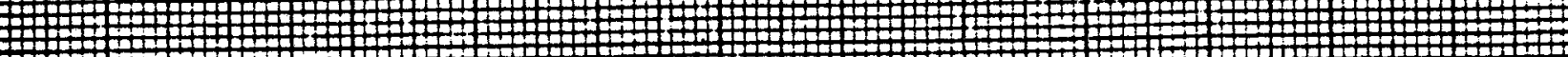

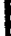
1

20

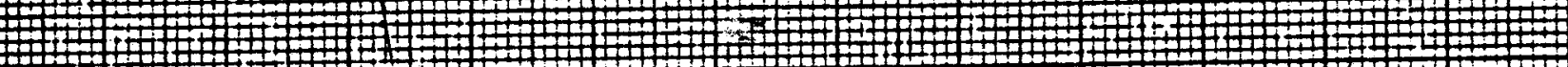
W W

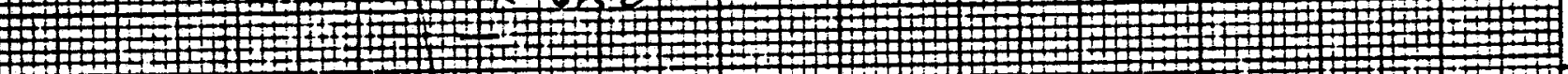

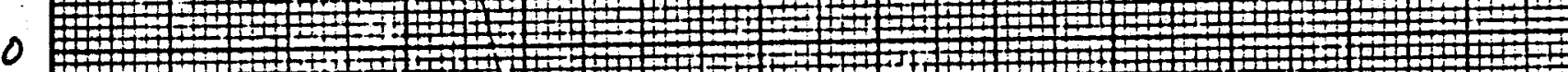

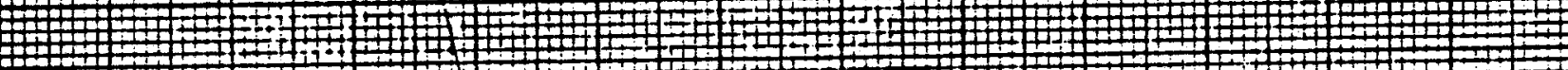

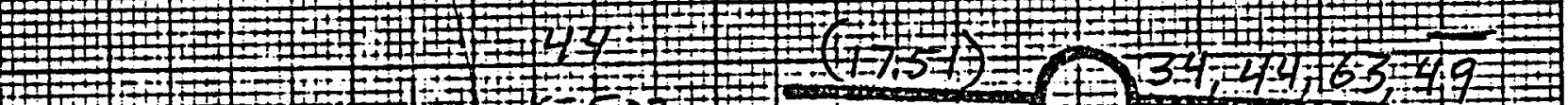

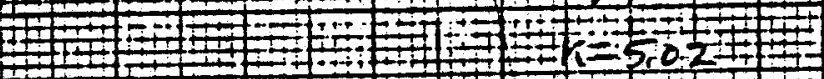

40 17+1372

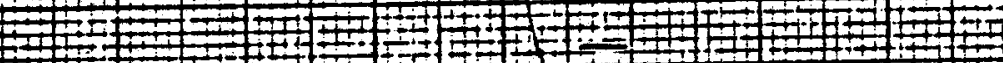

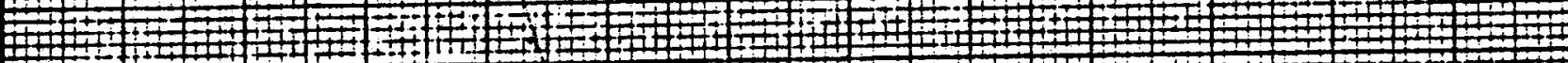

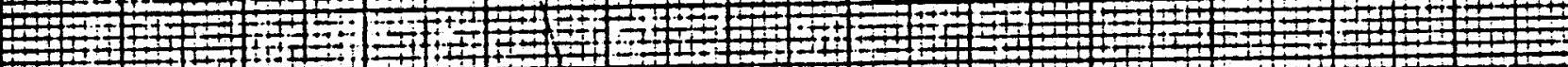

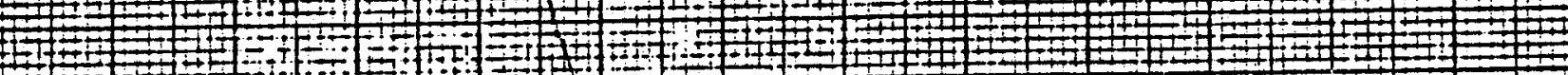

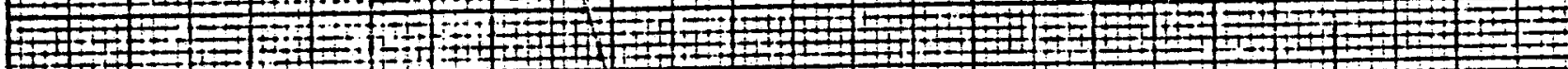

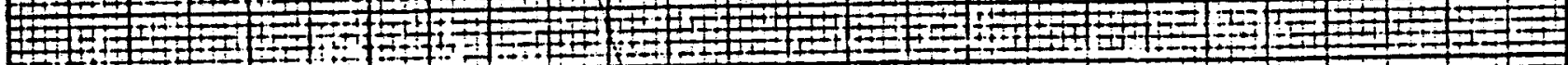

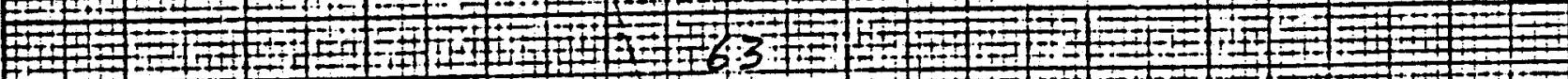

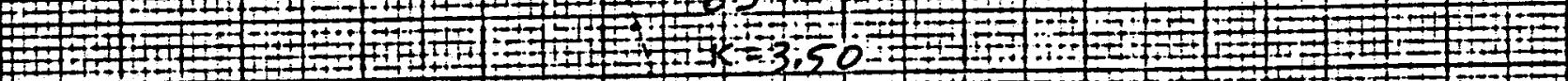
METERS

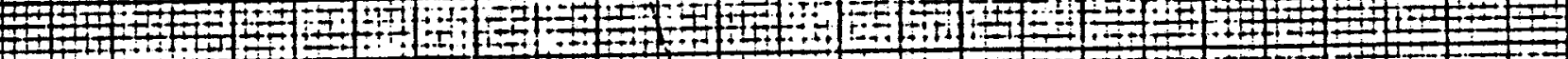

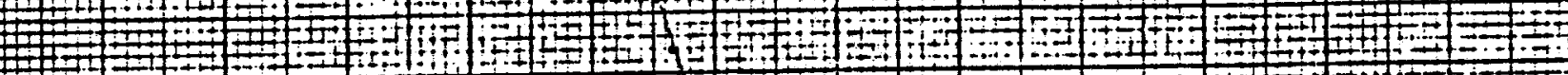

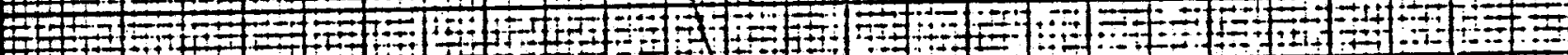

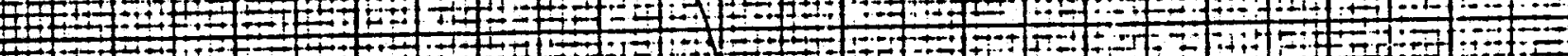

70

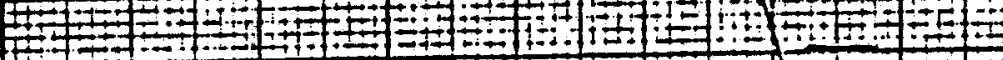

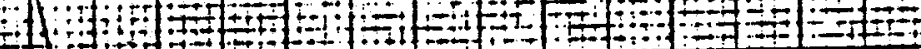

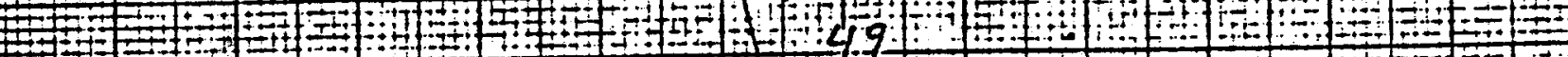

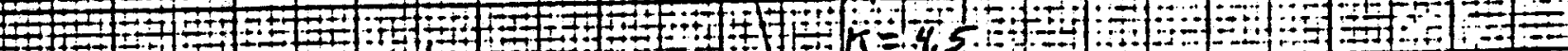

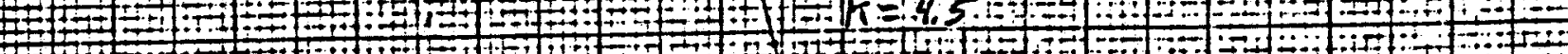

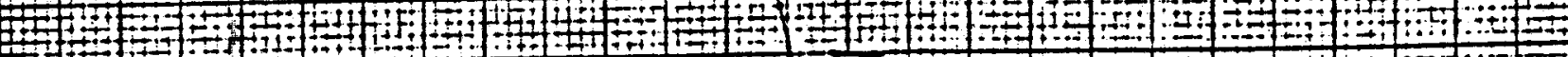

80

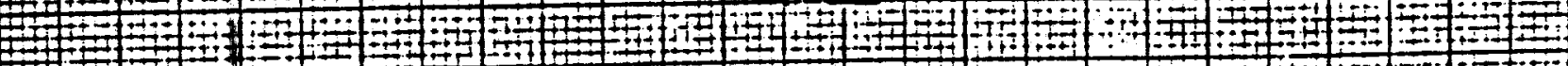

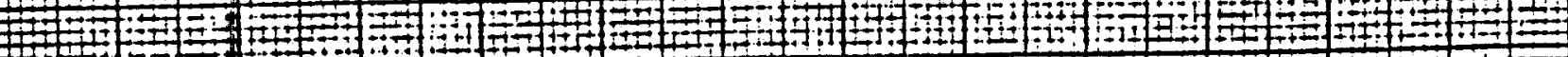

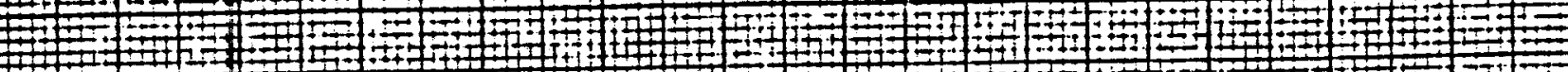

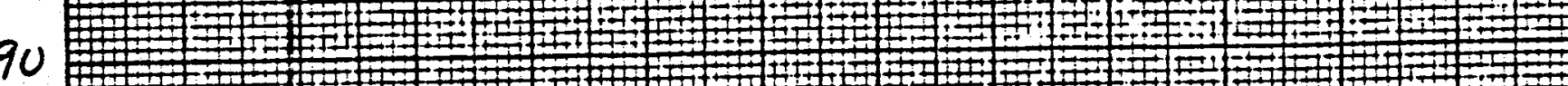

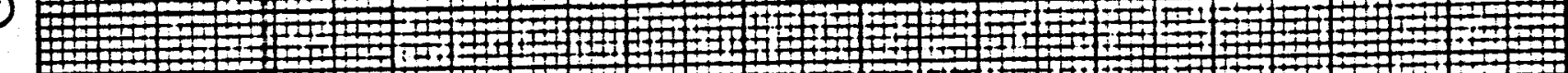

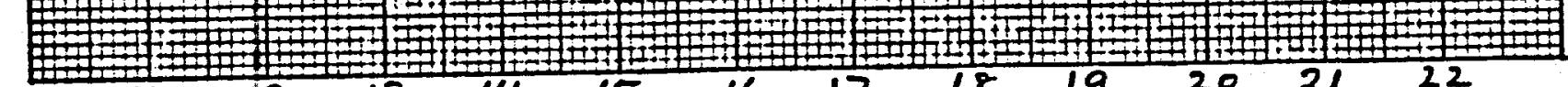
10 $11.12 \cdot 13,14 \cdot 15 \cdot 17$ 

Project: McCoy

Hole:

$864-93$

Elevation: 6030

Location: SWNW 35 T23N R40E

Geologist: Deymonaz
Date Drilled: $4-7-87$

Method: rotary air
Depth (m)

$0-28$

$28-67$

$67-75$

$75-80$
Description

Alluvium - tan, silt with angular gravels of sandstone, chert and volcanics. Increasing chert and sandstone with depth, possibly fanglomerate.

Alluvium/Crystal Tuffs - red to yellow-brown crystal tuffs in increasing amounts mixed with alluvium as above.

Crystal Tuff - med. gray to red to yellow-brown and firm as above. Altered groundmass of tuffaceous material and 10-15\% crystals of altered feldspars and minor quartz, mostly less than $1 \mathrm{~mm}$. Minor large biotite, common manganese deposition along fractures, rare small magnetite.

Tuff - it. gray, firm, brittle, granular mass of tuffaceous material and small $(<0.5 \mathrm{~mm})$ crystals of quartz and altered feldspars with rare small biotite and magnetite. Manganese common along small fractures. 


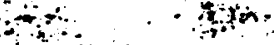

in

titas

AMAX EXPLORATION, INC.

TEMPERATURE/DEPTH IOG

is

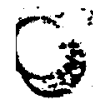

Property-Project Mc coy -864 Map MT. FIRY NW 'M scale $2.5^{\prime}$ State $M E Y, \because$ County LNADER Instrument sPafFors 46 In $; \cdot x+\cdots$

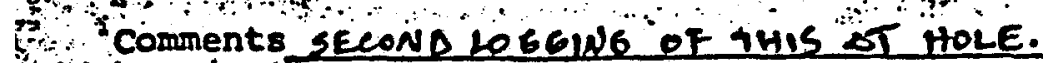

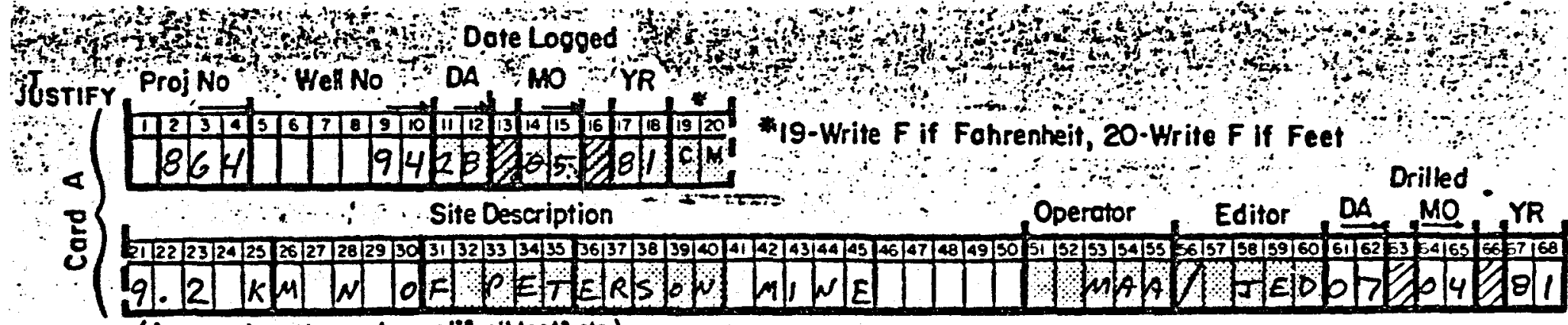
(Approx. locotion, water well?, oll teslt, etC). Date: Drilled $4-7-81$ Logged $05 / 28 / 81$
of $N W$ of $N E$ of $\sec 26$ Togged $22 N R 40 E$

Scole Unit

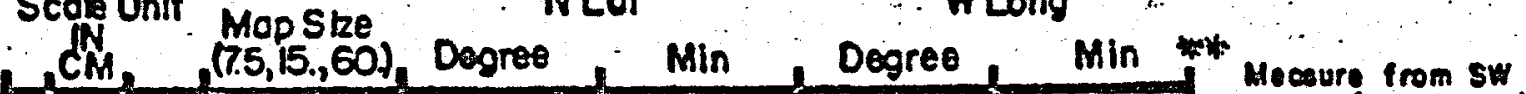

NLot

Mop Locotion * *

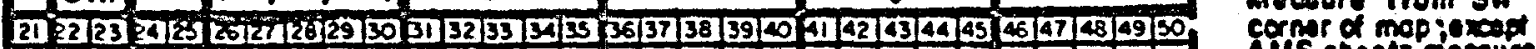

12

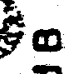

옹

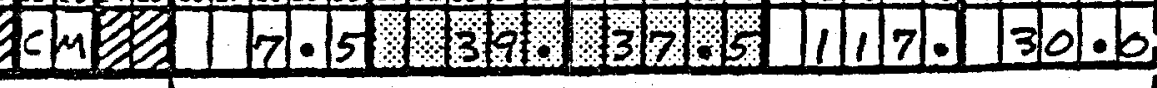

from botom camter

degres mork $(w,-)(E, t)$

\section{Northing}

Eosting

Elev

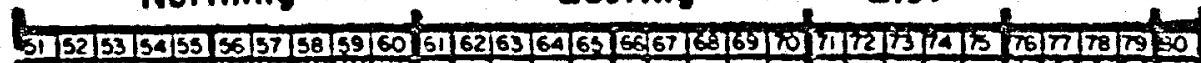

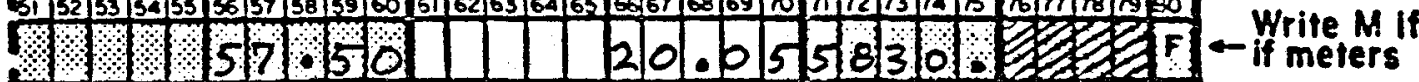

\section{Use decimals}

Segment $:=$ Depths

Stort
Conductivity

End $K \quad \Delta K$

Best cond. (-K)

Downward extropolations

$(-\Delta K)$

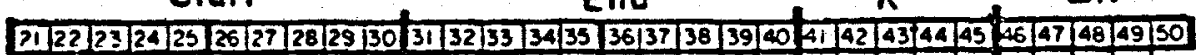

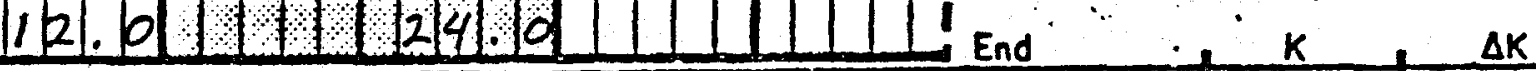

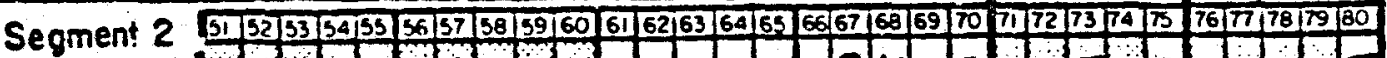

Segment 3

Stort $\rightarrow 1212124,0)$

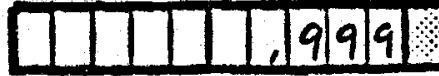

Segment 5

Segment 4

पा

Segment 7

Segment 6

पाD

Segment 9

Start $\longrightarrow$

Segment 8

Start $\rightarrow$

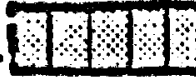

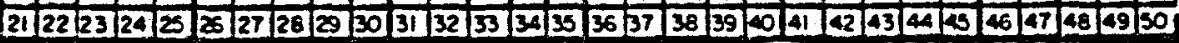


a

10

20

30

40

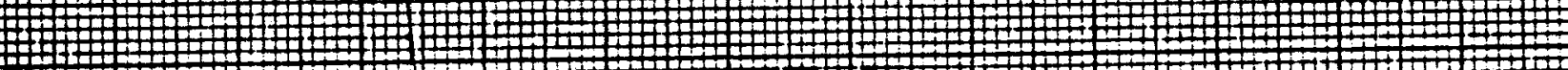

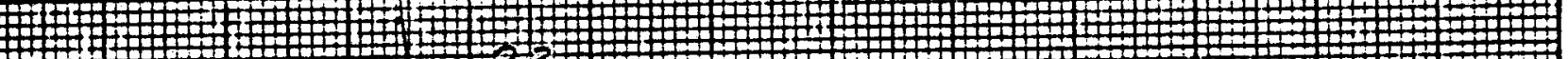

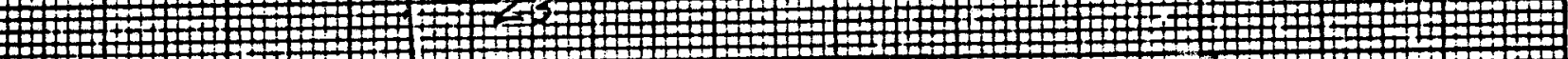
-

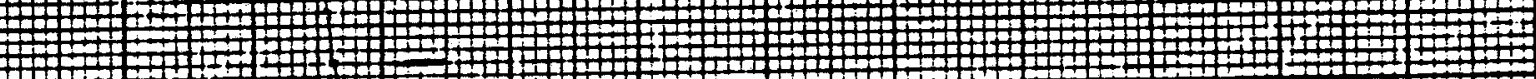

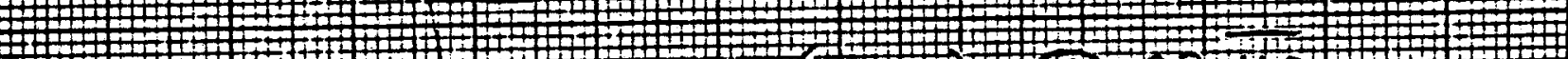
W

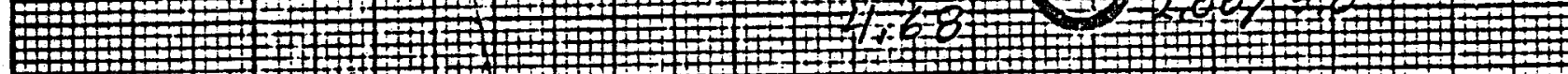

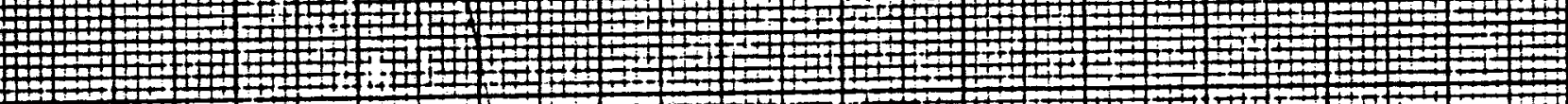

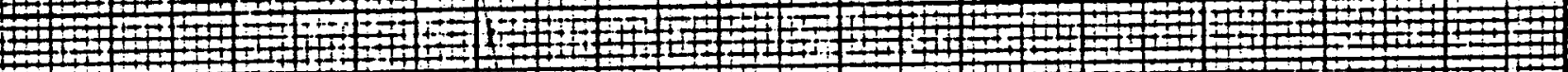

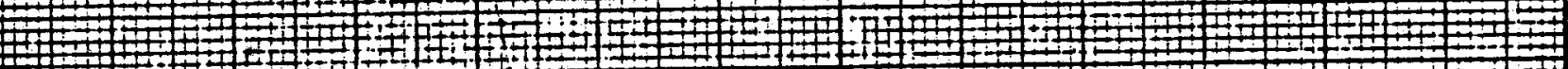

10

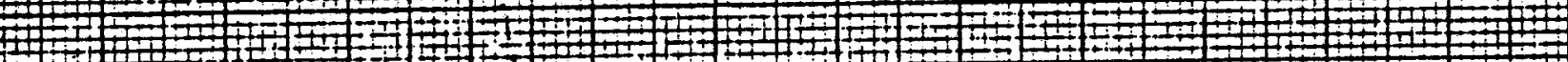

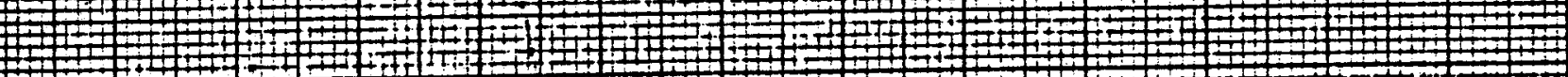

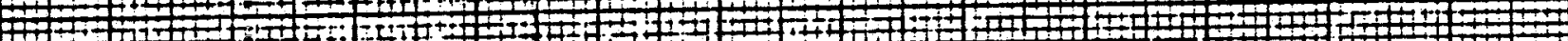

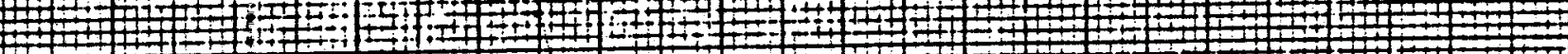

50

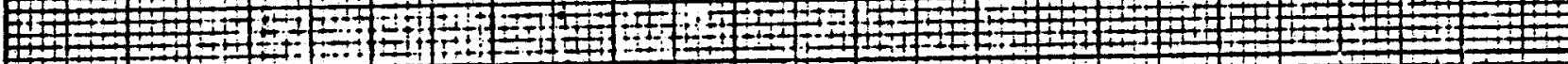

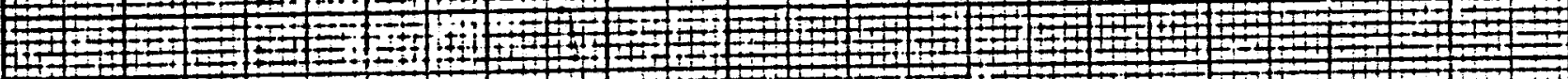

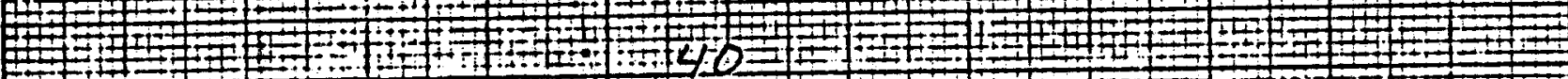

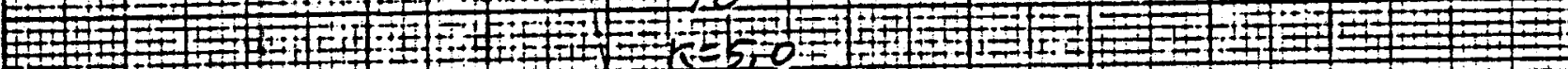
- 7.

60

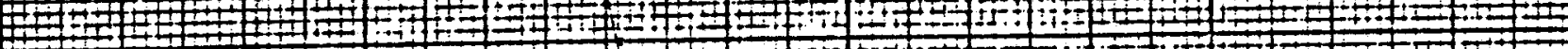

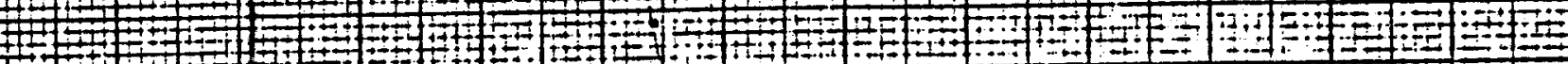

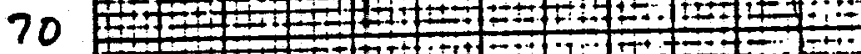

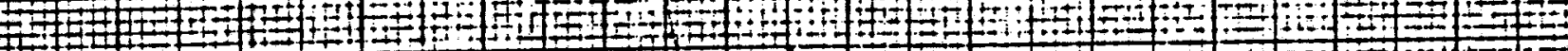

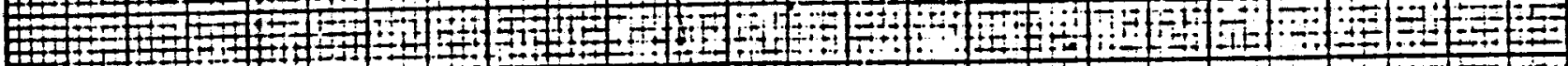

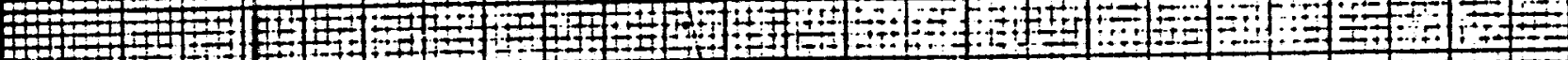

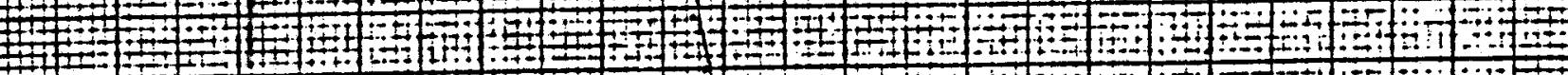

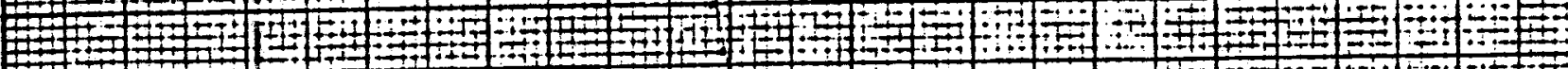

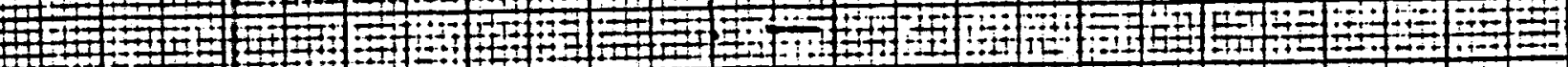

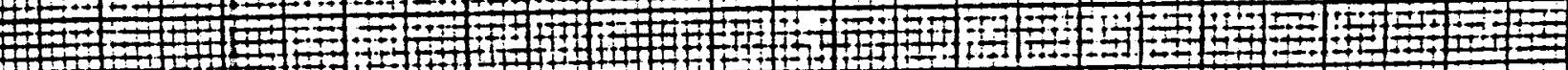

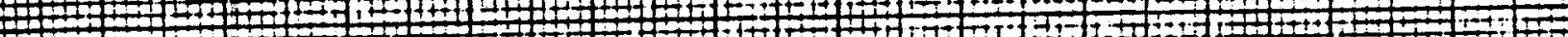

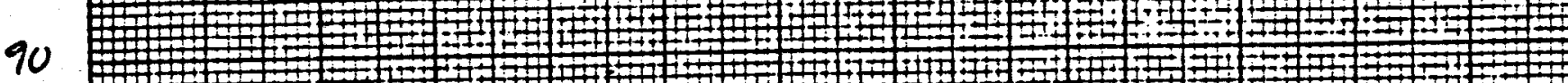

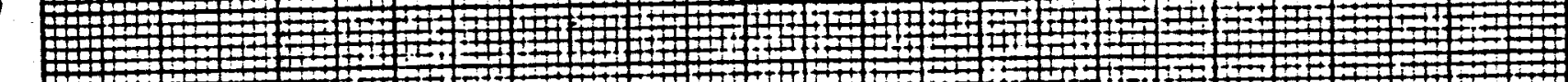

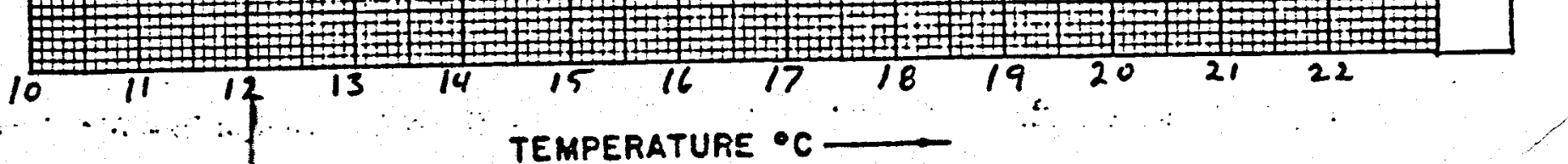




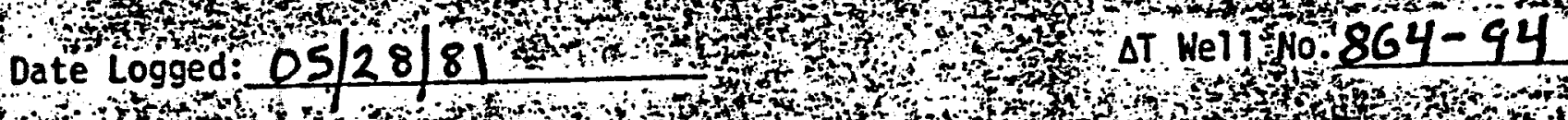

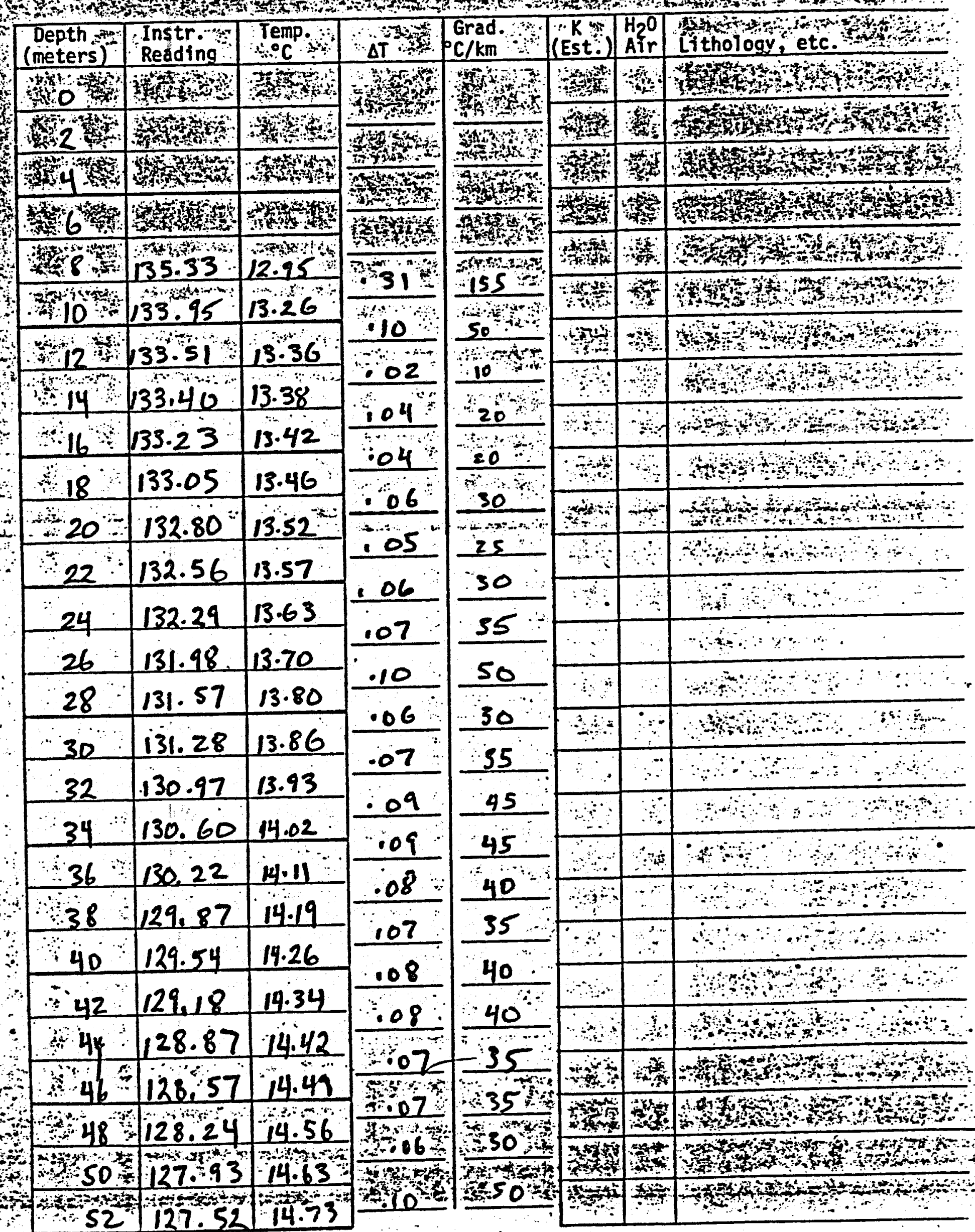


Date Logged: $05 / 28 / 81$

$\Delta T$ Well No. $864-94$

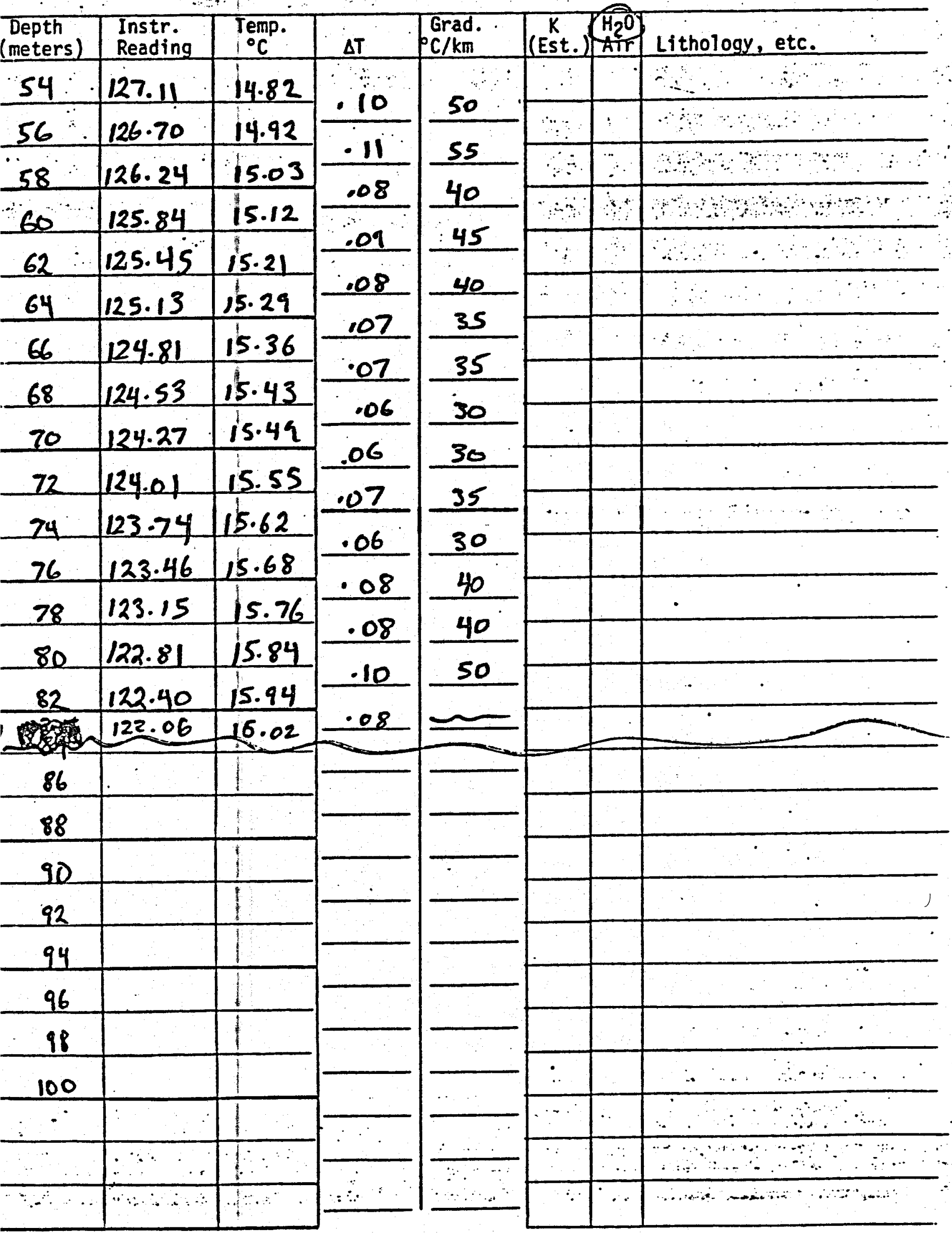




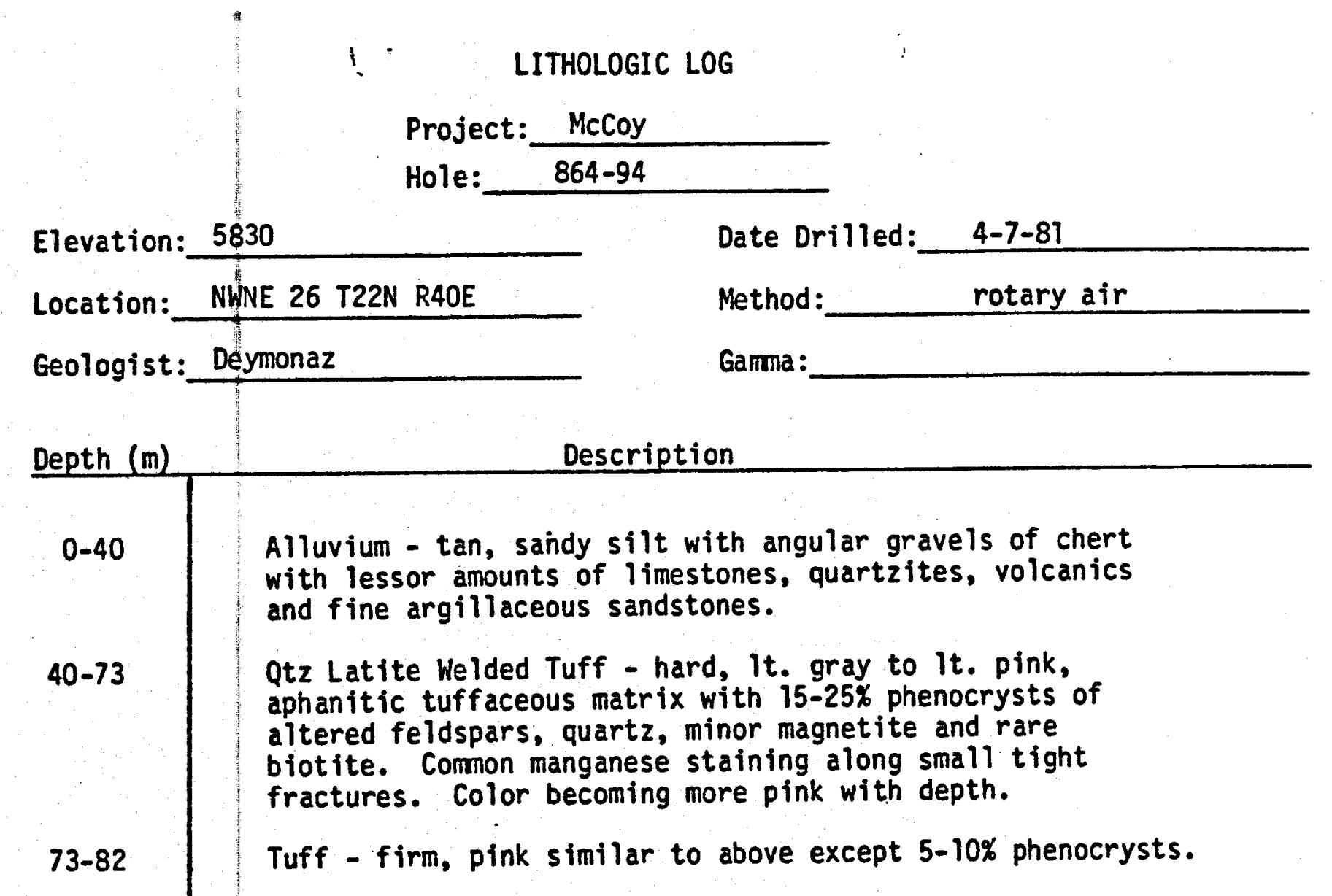


AMAX EXPLORATION, INC.

TEMPERATURE/DEPTH LOG
; Property-Project MC COY -864 Map GLB̈ERT CLEEK SW Scale T.5" state NeY. County LANPER. Instrument SPAFFRD H 46 Operator MARK AVERY comments SECONP if FINAL locolale of The AT Hol.
$\Delta T$ Well No. $864-95$ Depth Logged 27.1 meters Date: Drilled $4-7-81$ Logged os/28/81 of of NE of NE of sec I4 TZZN RiLOE Elevation 5500 (ifm

\section{Date Logged}

jTSTIFY Proj No Well No DA MO YR

*19-Write $F$ if Fohrenheit, 20-Write $F$ if Feet

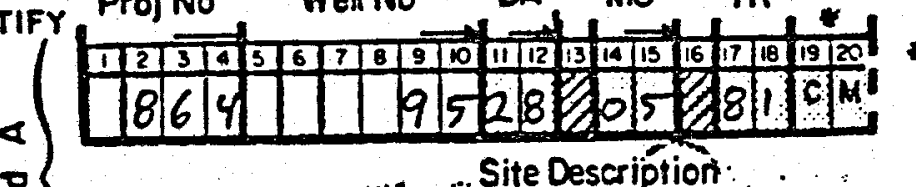

?

.. Site Descriṕtion:

Operotor Editor DA MO Y YR

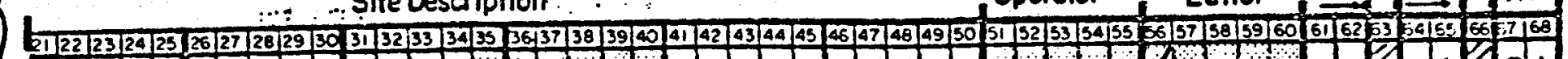

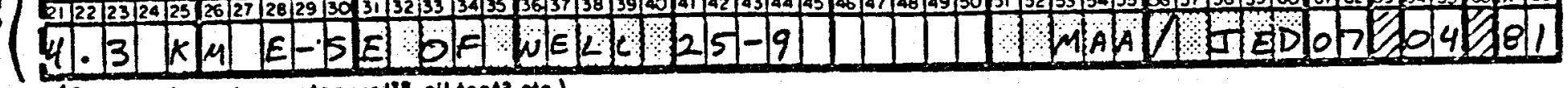

(Approx. location, woter well?, oll test?, etc.).

它

Scole Unit NLot

Mop Locotion * *

IN MopSize

CM, $(7.5,15,60)$, Dogree, Min Degree, Min *w

Min WLong

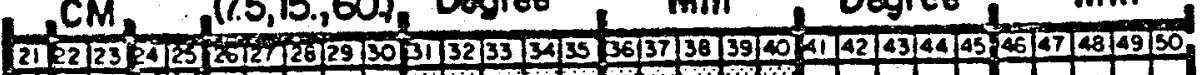

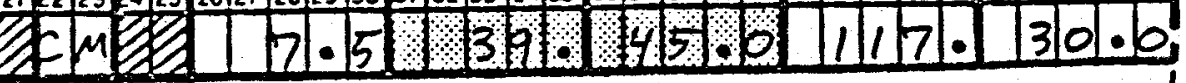
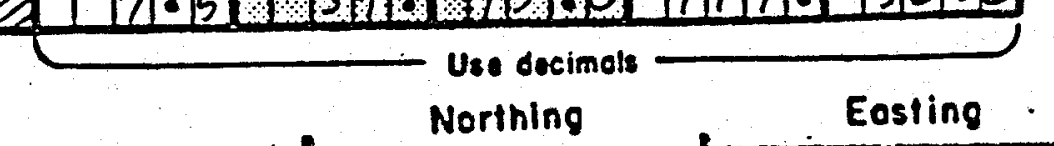

Northing

Eosting

Elev

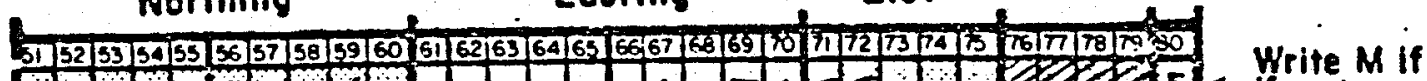

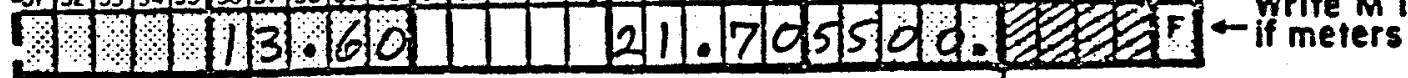

Use decinats

Segment $:=$ Depths

Conductivity

Start End $K$. $\Delta K$

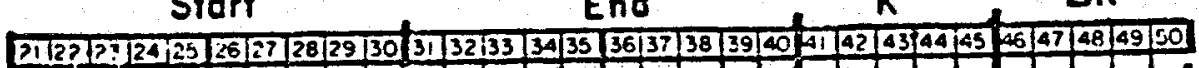

Mecoure from SW

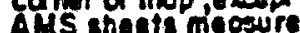

rrom bot tom center

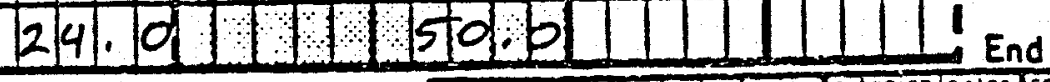

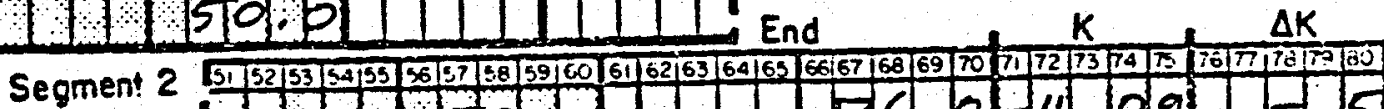

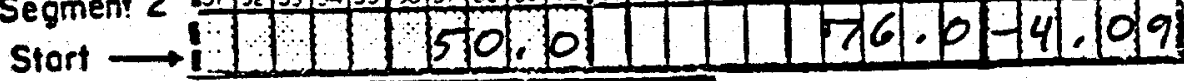

Segment 3

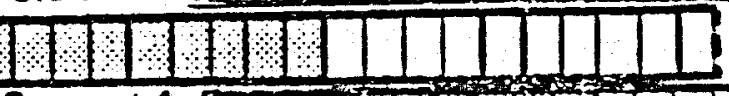

Segment 4

Segment 5

Stort

Best cond. $(-K)$

Downward extropolations

$(-\Delta K)$

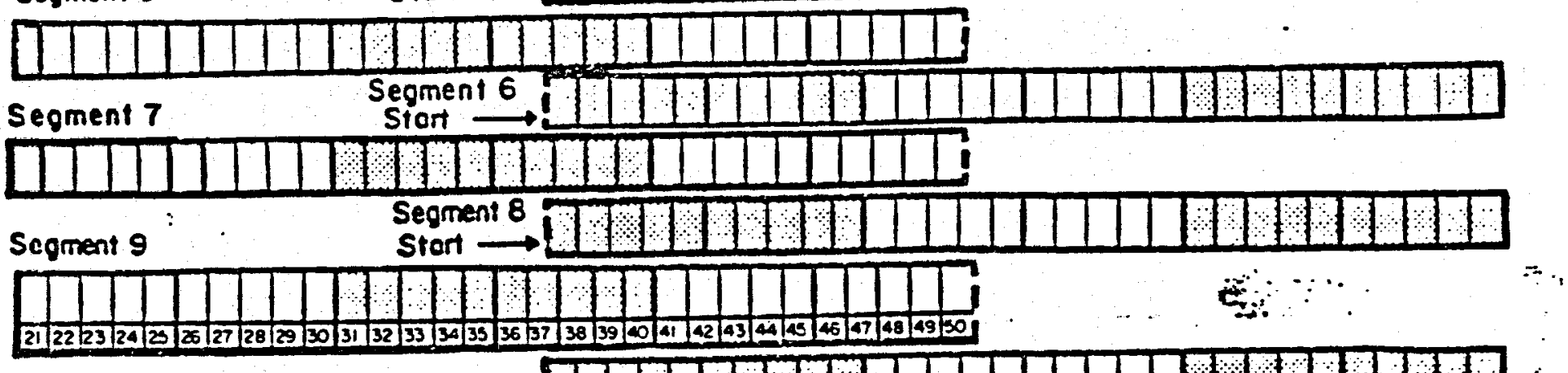

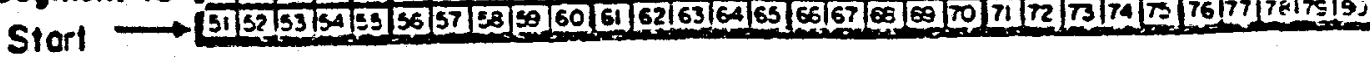




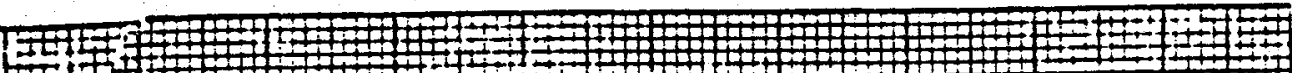

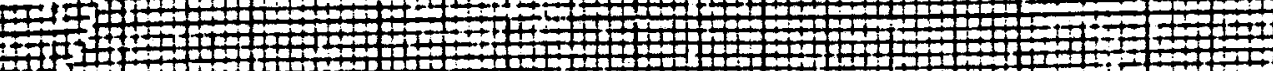
HOLE $864-95$ Qal W W

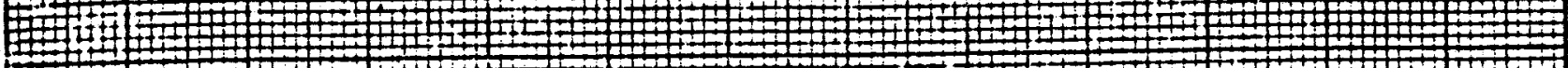

10

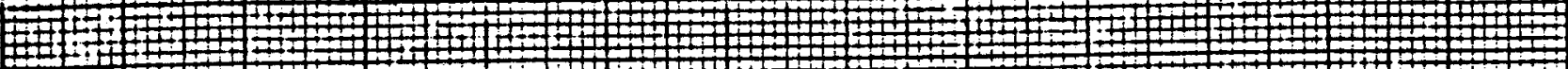

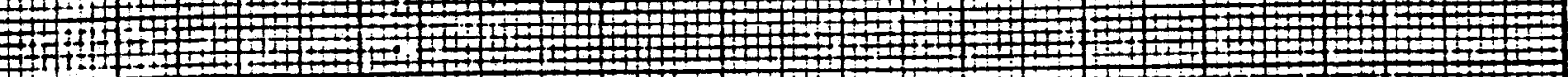

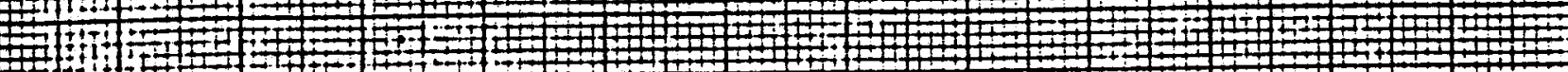

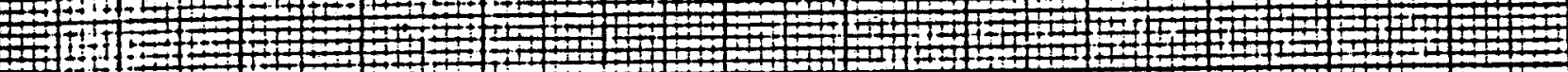

20

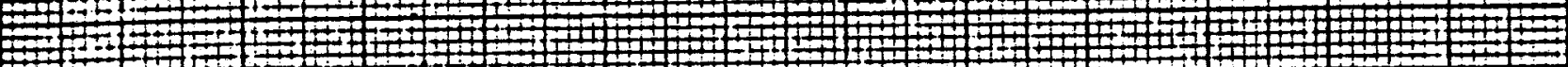

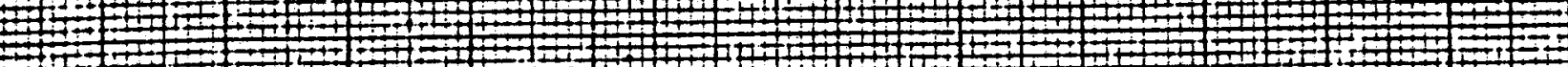

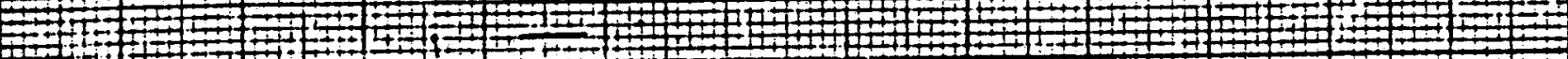

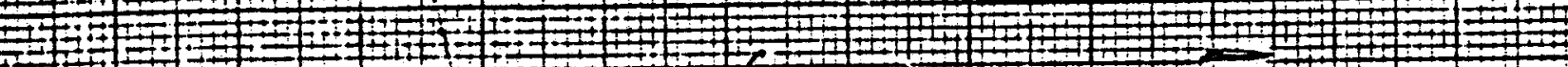

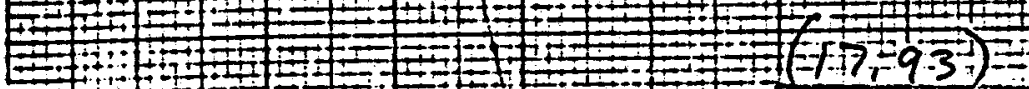

30

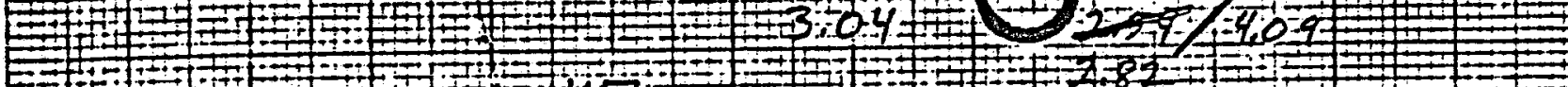

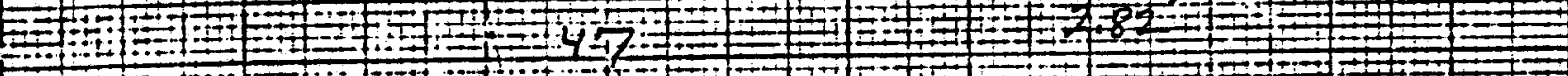

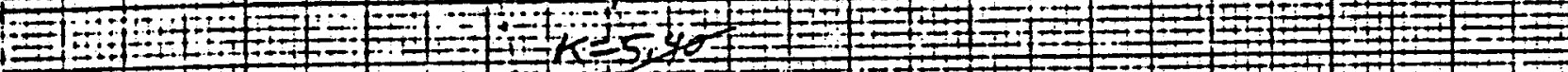

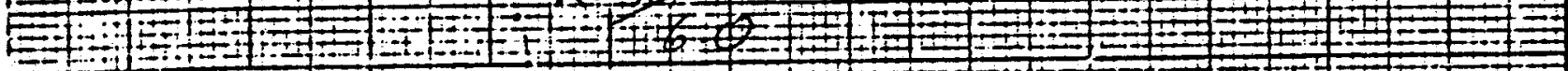

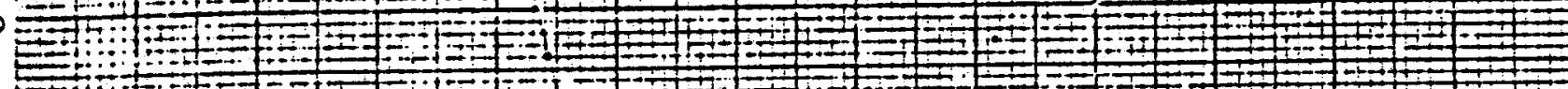
Oil:

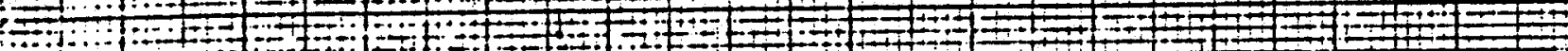

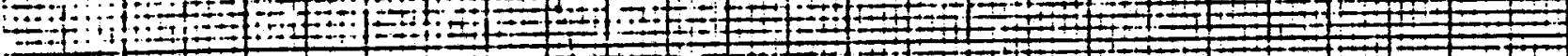
1.

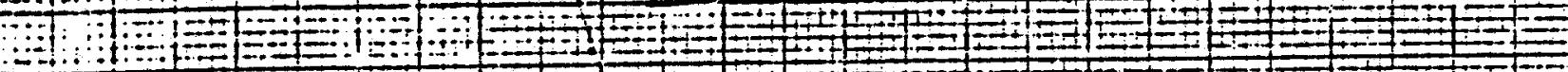

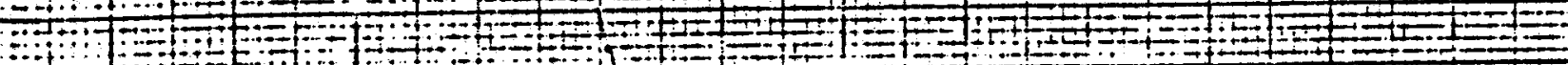

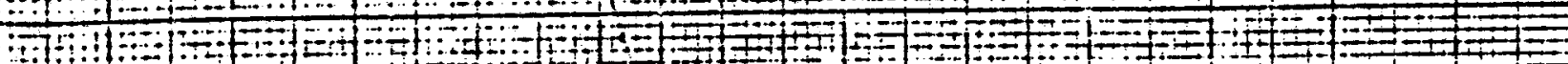

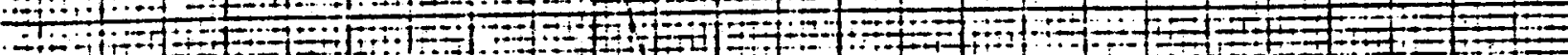


Date Logged: $05 / 28 / 81$

$\Delta T$ Well No. $864-95$

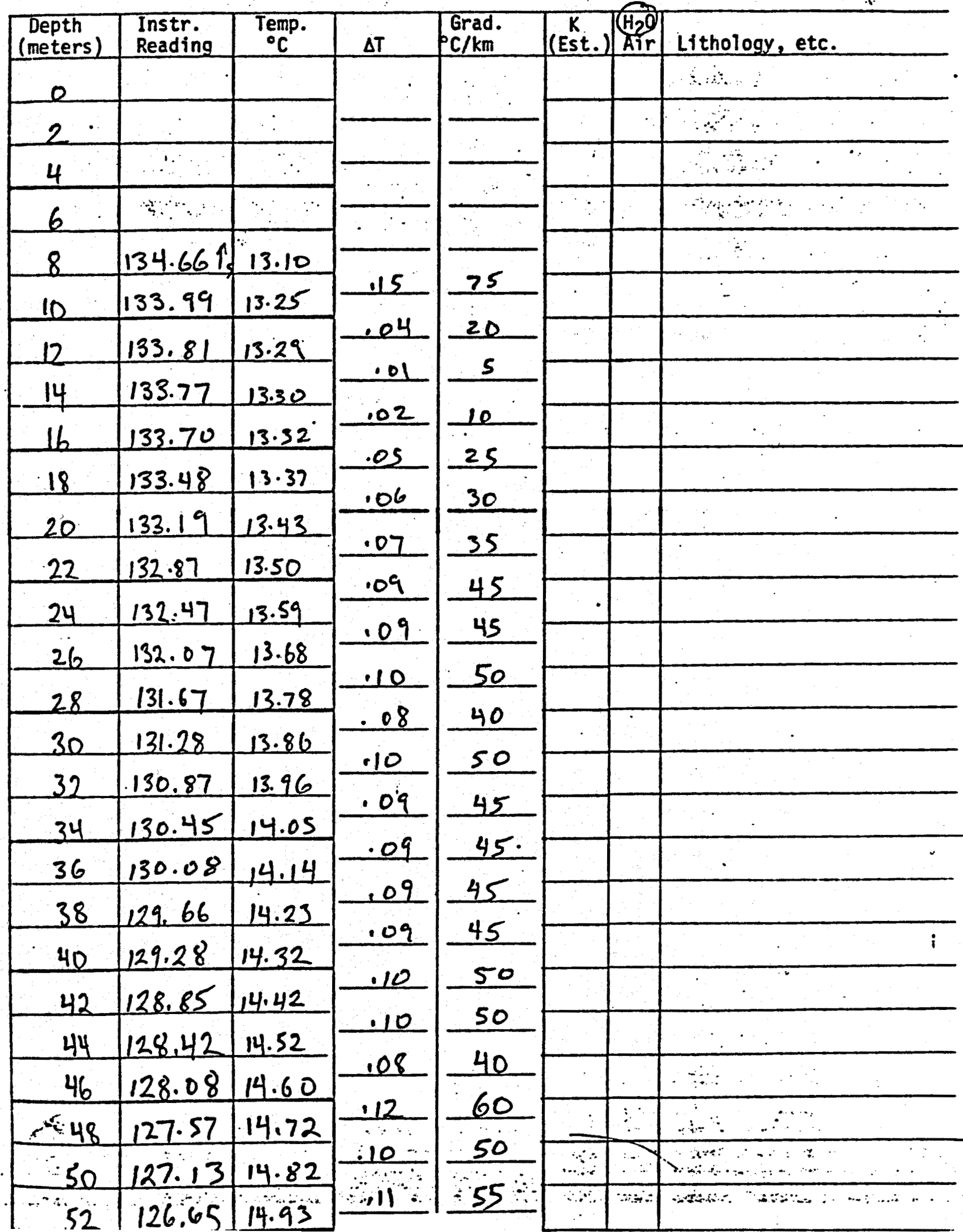


.te Logged: $05 / 28 / 81$

$\Delta T$ Well No. $864-95$

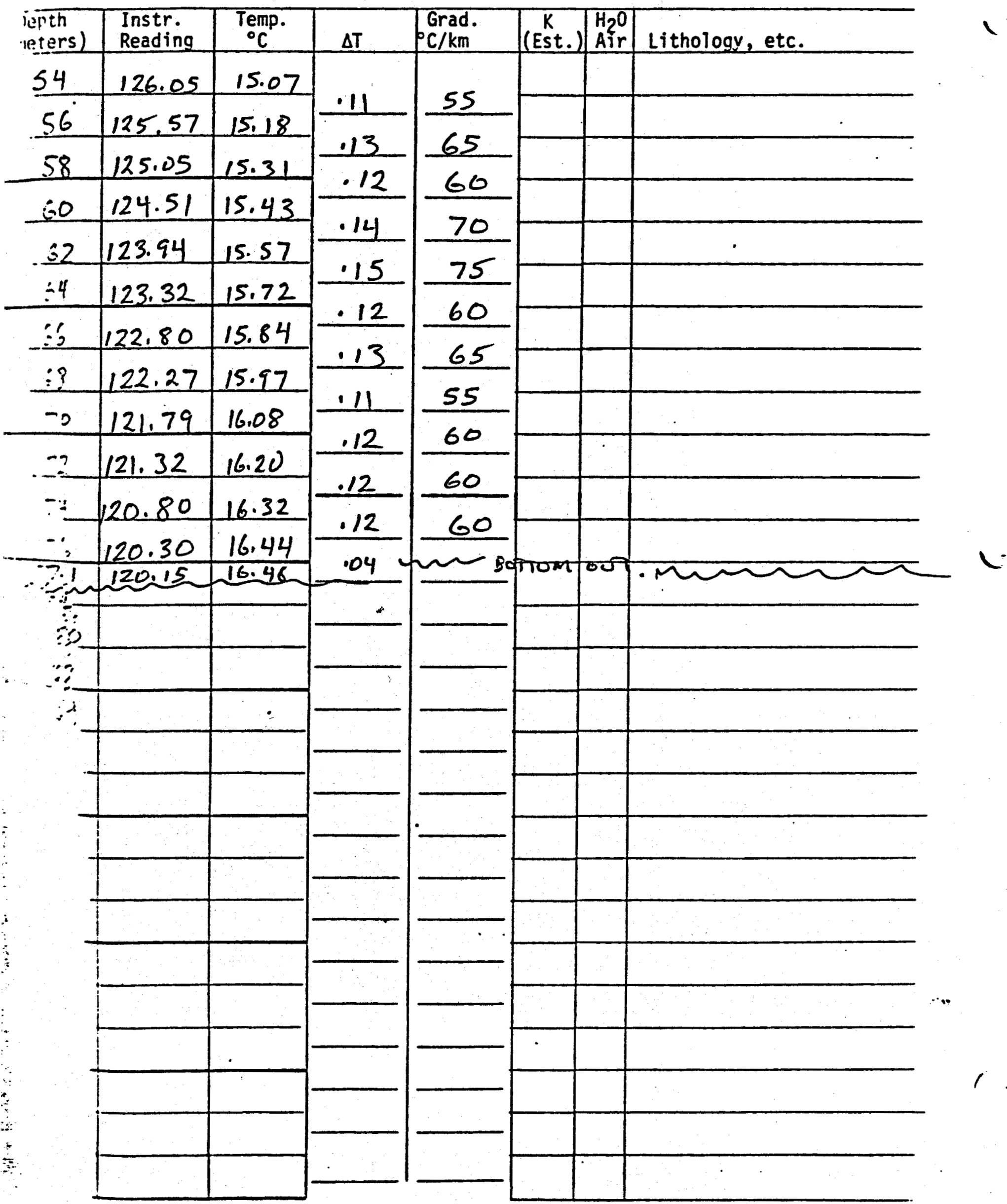


Project: McCoy

Hole:

$864-95$

Elevation: 5500

Location: NENE 14 T22N R4OE

Geologist: Deymonaz
Date Drilled:

$4-7-81$

Method: rotary air

Ganma:
Depth (m)

$0-2.5$

2.5-61

$61-79$
Alluvium - tan, sandy silt with angular gravels $(3 \mathrm{~mm}-5 \mathrm{~cm})$ of intermediate volcanics, black limestones and minor cherts.

Welded Crystal Tuff - quartz latite, hard, it. pink aphanitic matrix with phenocrysts $(1-4 \mathrm{~mm})$ of quartz, $k$-spar, and altered plagioclase comprising 15-30\% of rock. Rare biotite, magnetite and hornblende. Common manganese deposition along small tight fractures. Rare, small lithic fragments.

Crystal Tuff - it. gray to pink, firm-hard, groundmass of tuffaceous material, and small lithic fragments and quartz grains $(<0.5 \mathrm{~mm})$. $15 \%$ large biot ite phenocrysts $(2-5 \mathrm{~mm})$ and smaller, altered feldspars, of ten apple green and translucent. Trace of magnetite. 


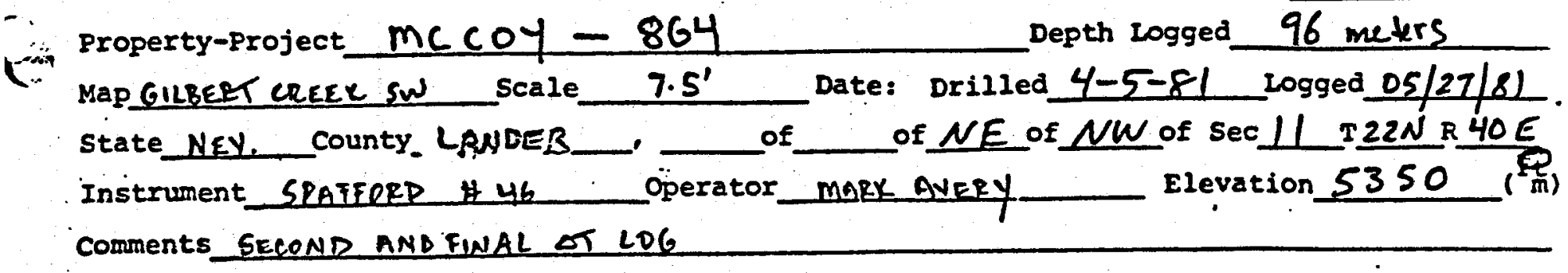

$\Delta T$ พell No. $864-96$

\section{Date Logged}

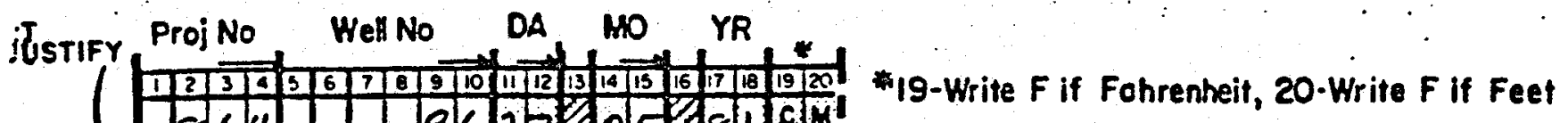

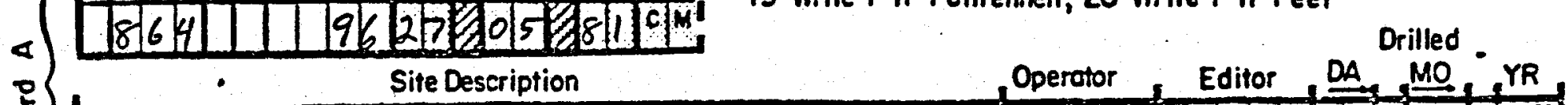

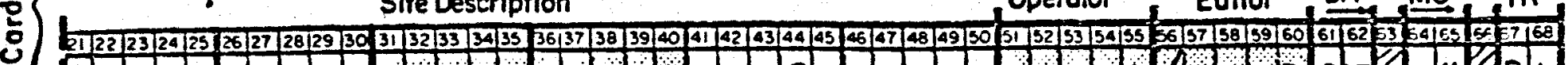

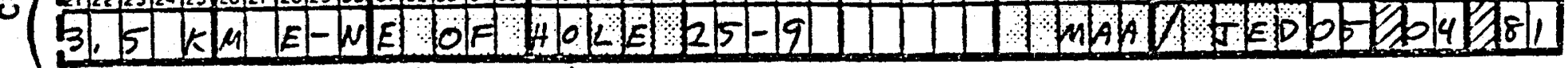

(Approx. locetion, woter well!, oll test?, etc.).

0
0
0
0

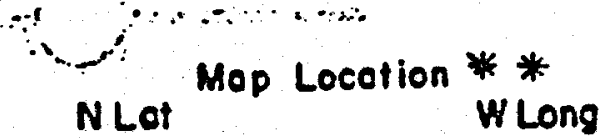

\section{Scale Unit Mop Stze NLot WLong}

CM, $(7.5,15,60)$, Degree, Min, Degree, Min ** Mecoure from sw

21 22 2314435

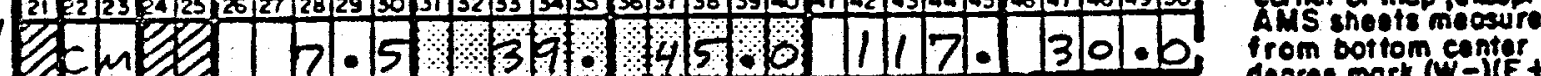

Usa docimols

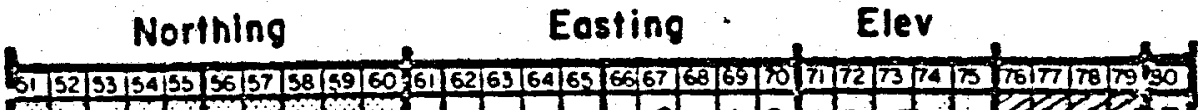

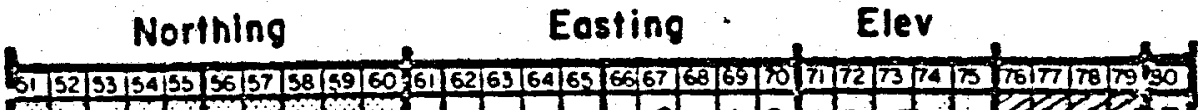

dogree mark $(W,-)(E, t)$

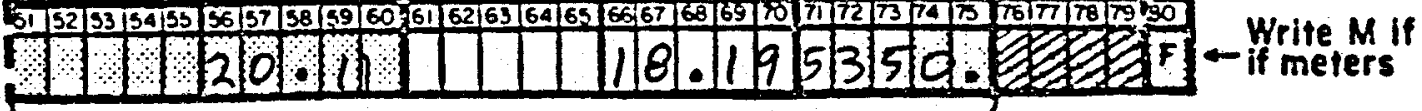

Use docimals

Segment $!=$ Depins

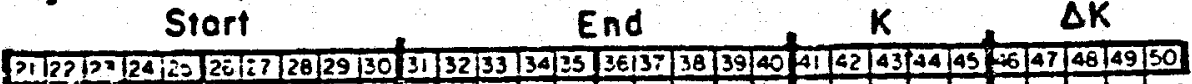

Conductivity

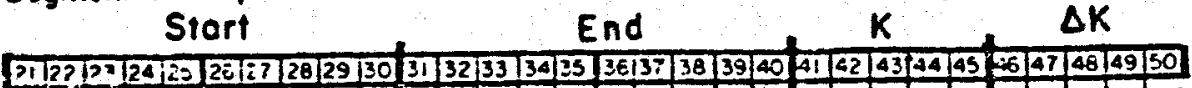

Best cond. $(-K)$

Downward extropolations $(-\Delta K)$

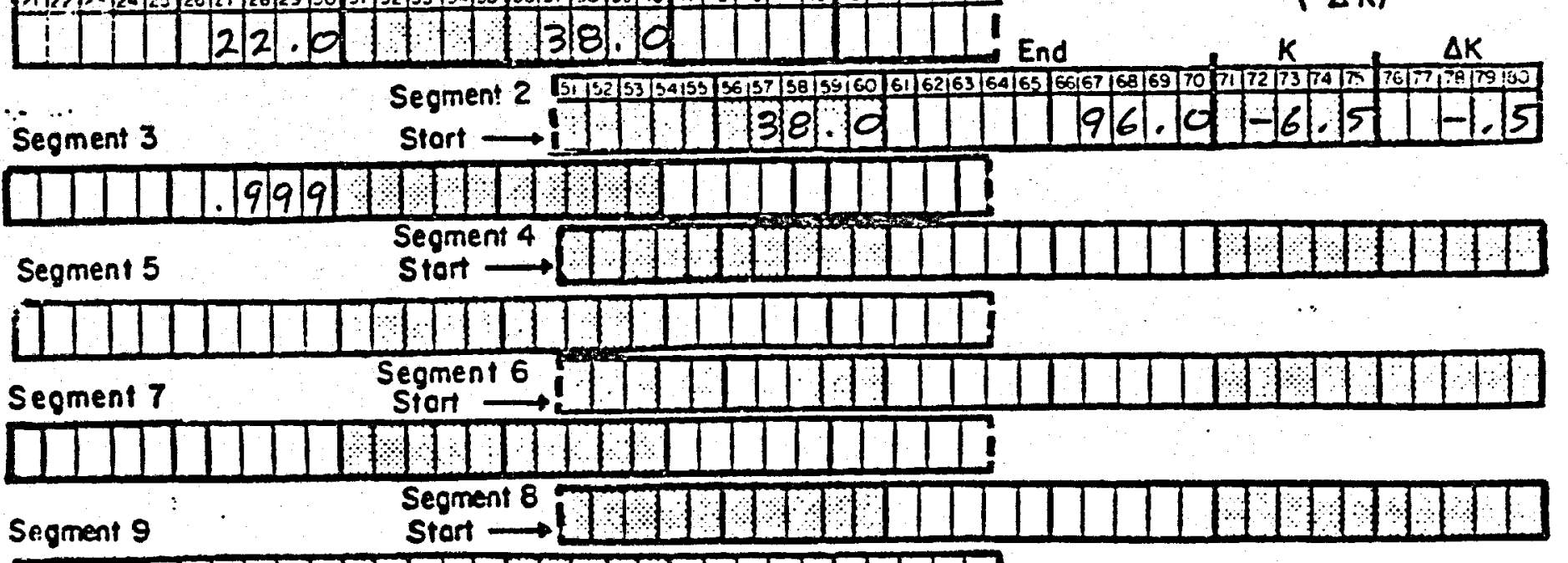

Segment 9

Stort

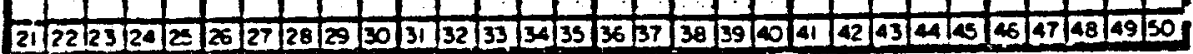

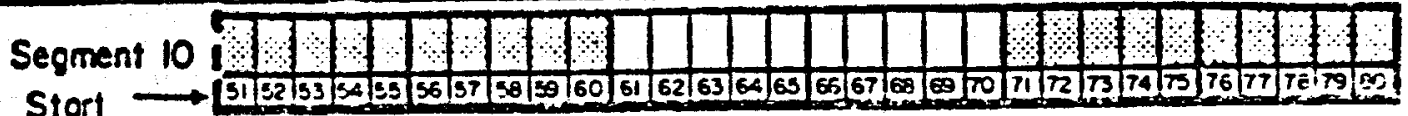




\section{a.

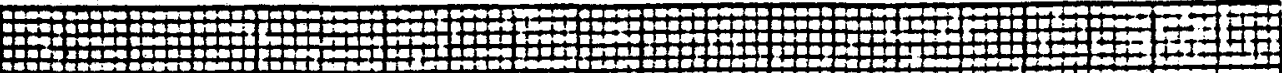 W

10

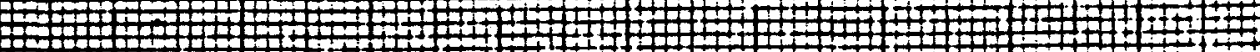

T210 功

20

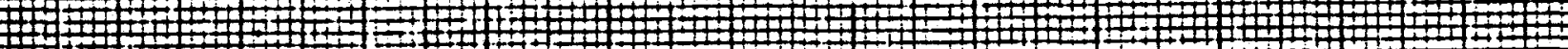

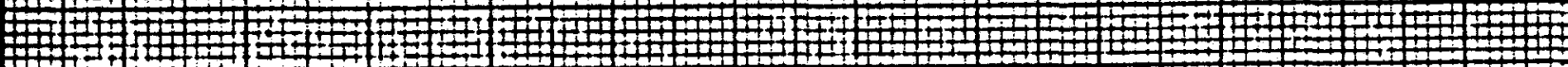
1

20

30

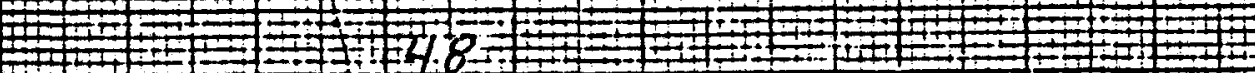

1711 2 1 W

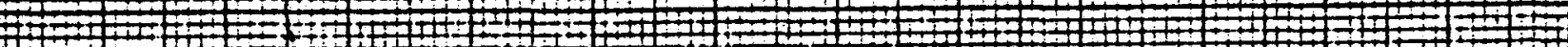

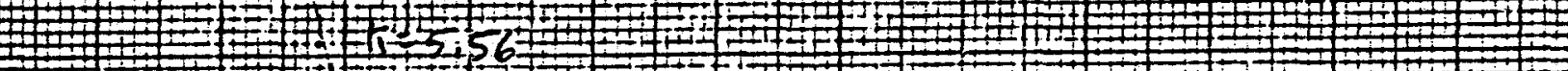

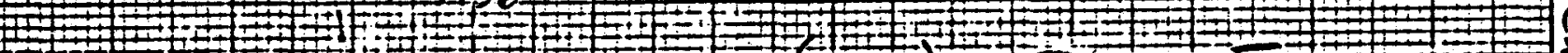

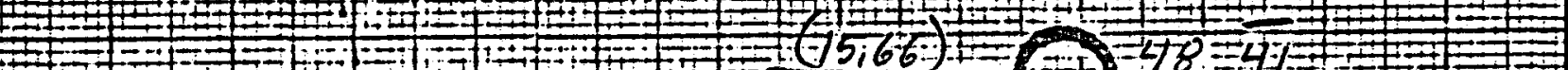

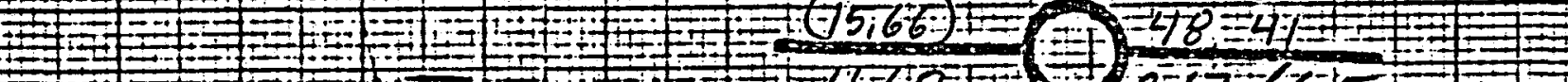

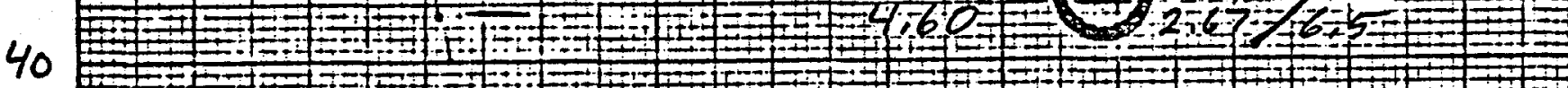

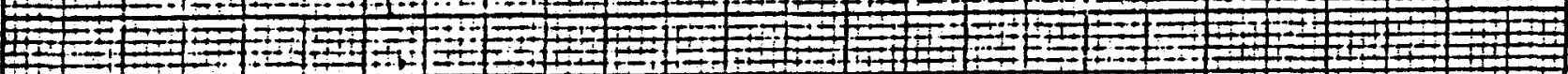

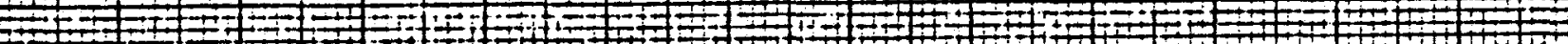

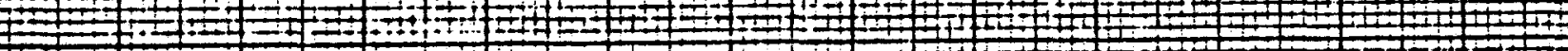

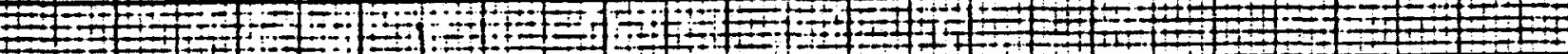

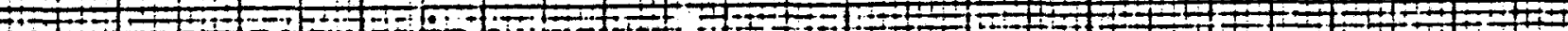

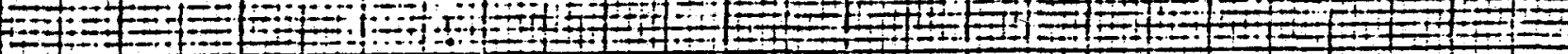

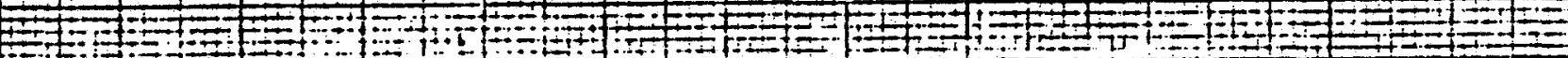

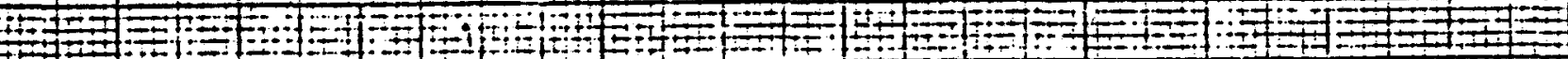

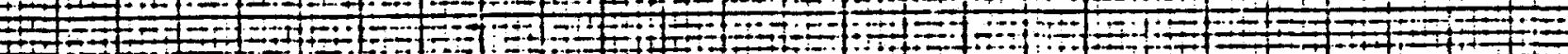
AETERS

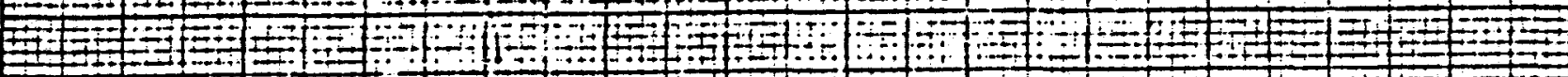

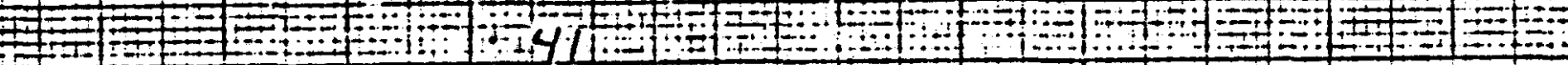
(1)

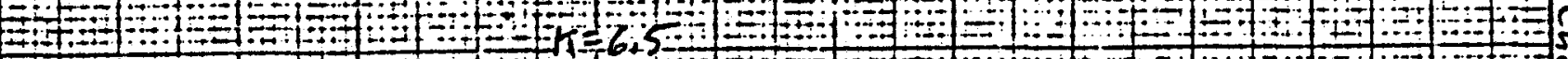

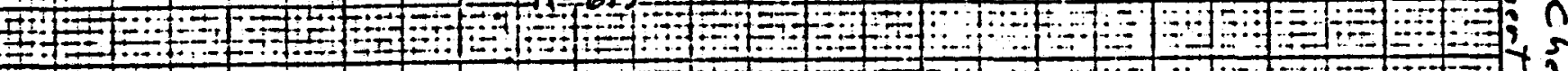

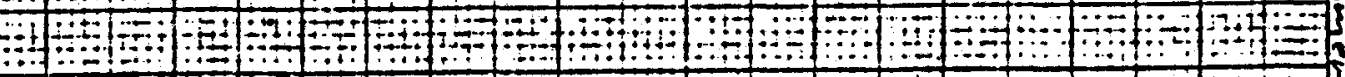
-

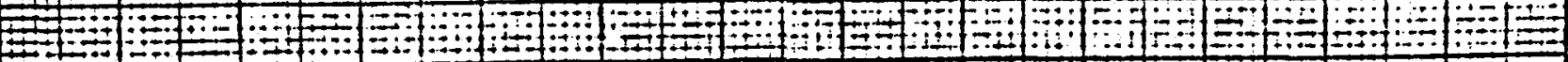

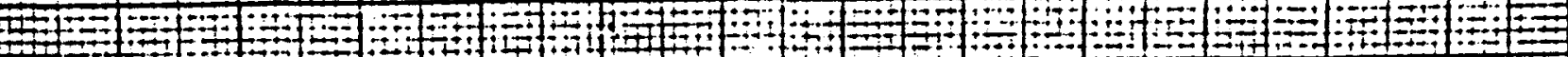

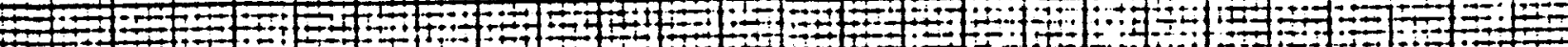

90

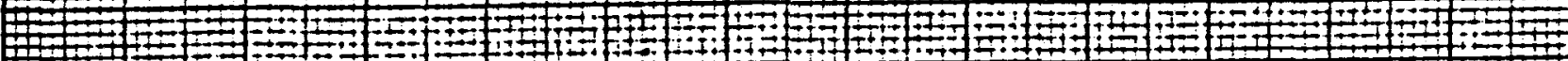

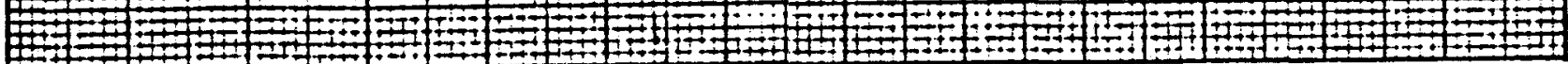


Date Logged: $05 / 27 / 81$

$\Delta T$ Well No. $864-96$

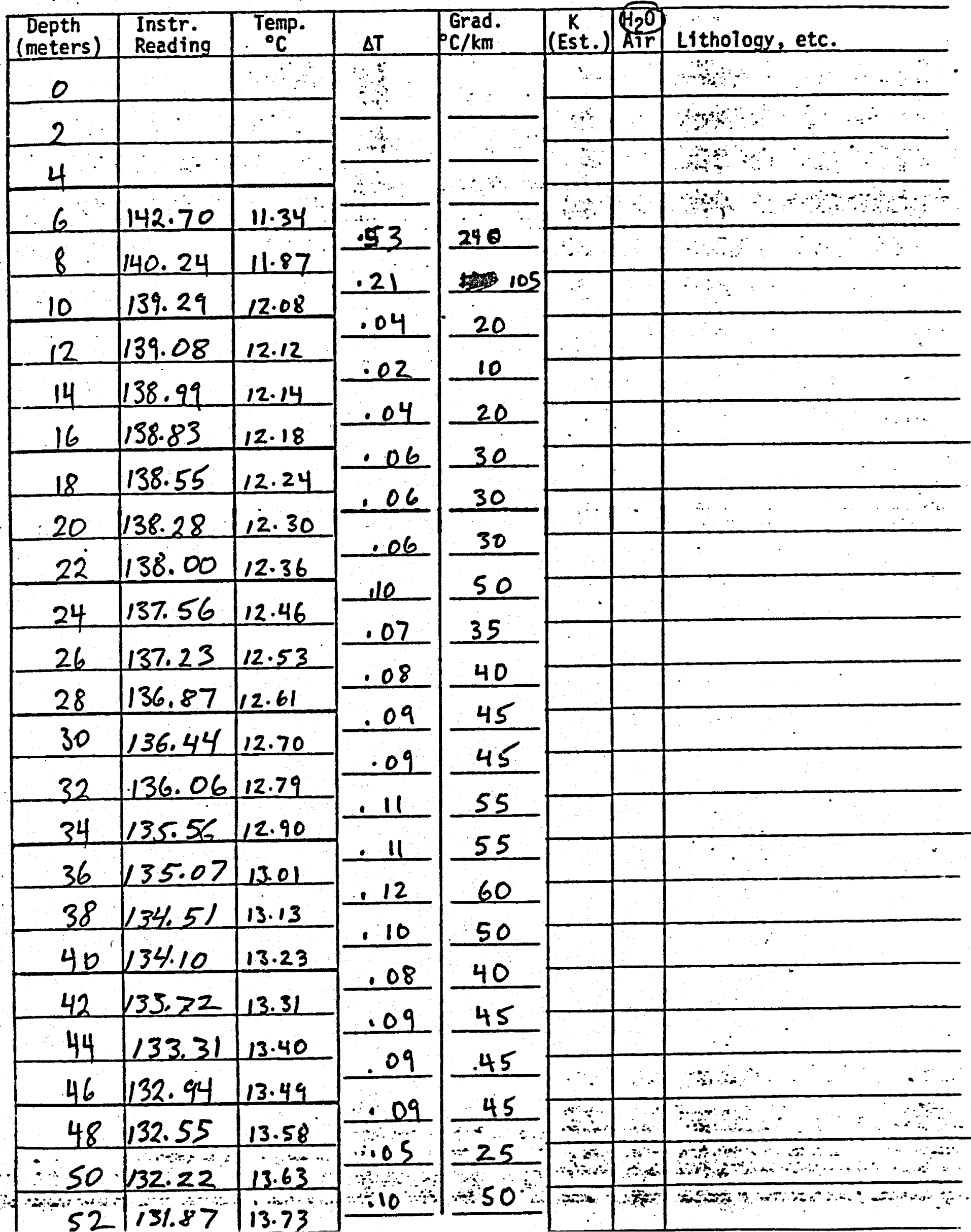




\section{LITHOLOGIC LOG}

Project: McCoy

Hole: $864-96$

Elevation: 5350

Location: NENW 11 T22N R4OE

Geologist: Deymonaz
Date Drilled: 4-5-81

Method: rotary air

Garma:
Depth (m)

$0-1.5$

$1.5-4$

4-29

$29-53$

53-95

Alluvium - tan, sandy-silt with minor angular gravels of chert, limestone and volcanics.

Gravels - anguiar to subangular gravels of cherts, volcanics and limestone. Dry poorly consolidated.

Alluvium - as in $0-1.5 \mathrm{~m}$ (hole very dry to $29 \mathrm{~m}$ ).

Chert or Fanglomerate - It. greenish-gray, gray and red cherts pervasively fractured and iron-stained, considerable variation within each sample, very similar to fanglomerate material in 864-92.

Chert or Fanglomerate - as above, except predominately it. gray and reddish. 
AMAX EXPLORATION, INC.

TEMPERATURE/DEPTH LOG

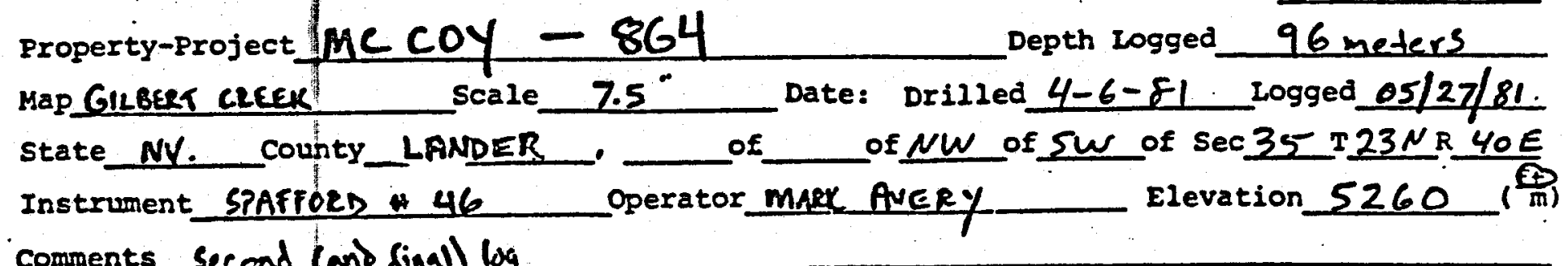

$\Delta T$ Well No. $864-97$

coments Second lant final) log

\section{jEstif \\ (1) \\ ?}

Proj Dote Logged

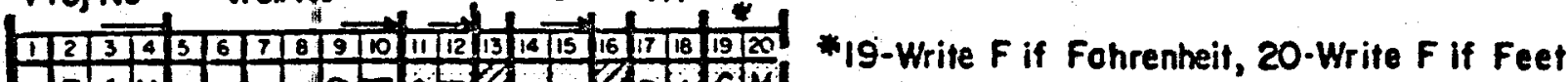

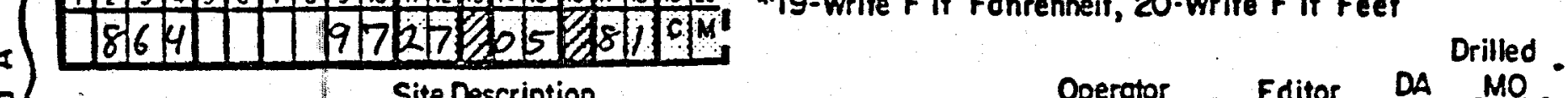

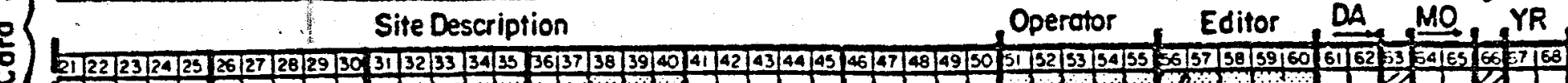

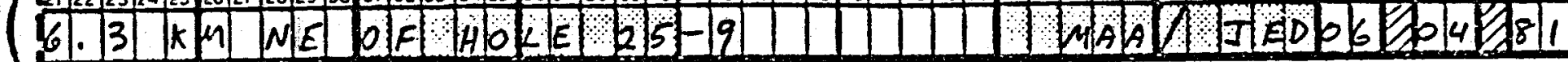
(ADprox. locotion, woler well?, oil test?, etc)

Scak Unit

N Lot

Mop Locotion * *

CM, $(7.5,15,60)$, Degree, Min, Degree, Min **

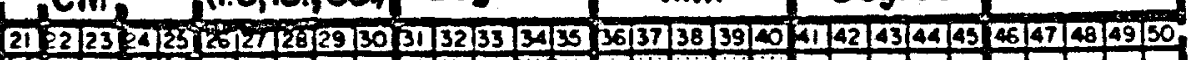

(7)

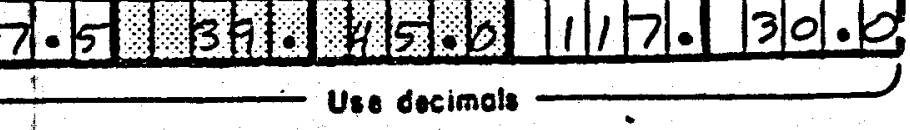

carmer of mop iexpopt

S sneets mocsurs

from bottom canter

Northing

Eosting

Elev

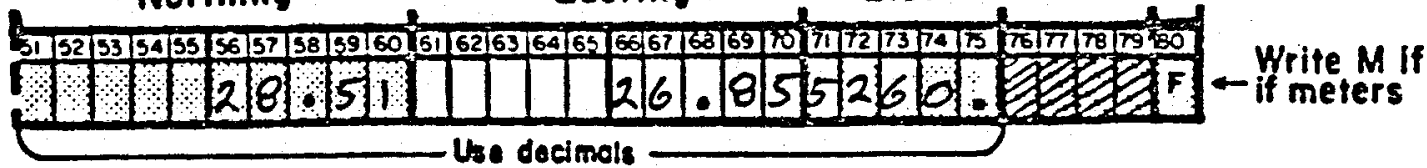

Segment $:=$ Depths

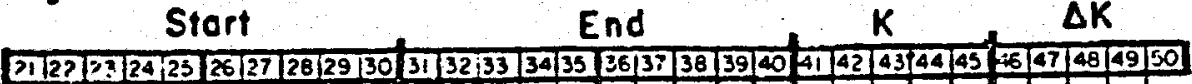

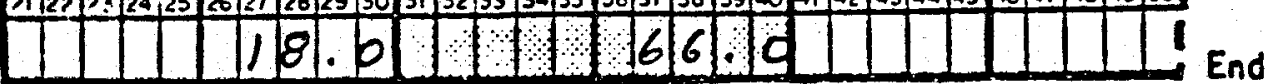

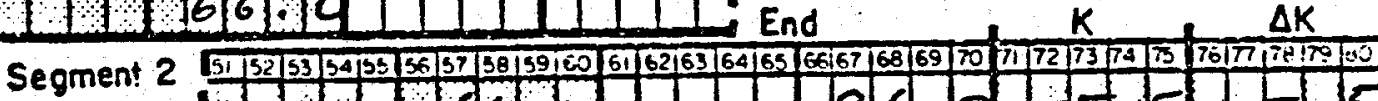

Segment 3

Stort

TDDDT.999

Segment 5

Segment 4

Stort

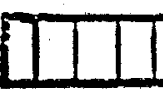

Segment 7

Segment 6

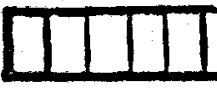

Segment 9
Best cond. (-K)

Downword extropolations

$(-\Delta K)$ 


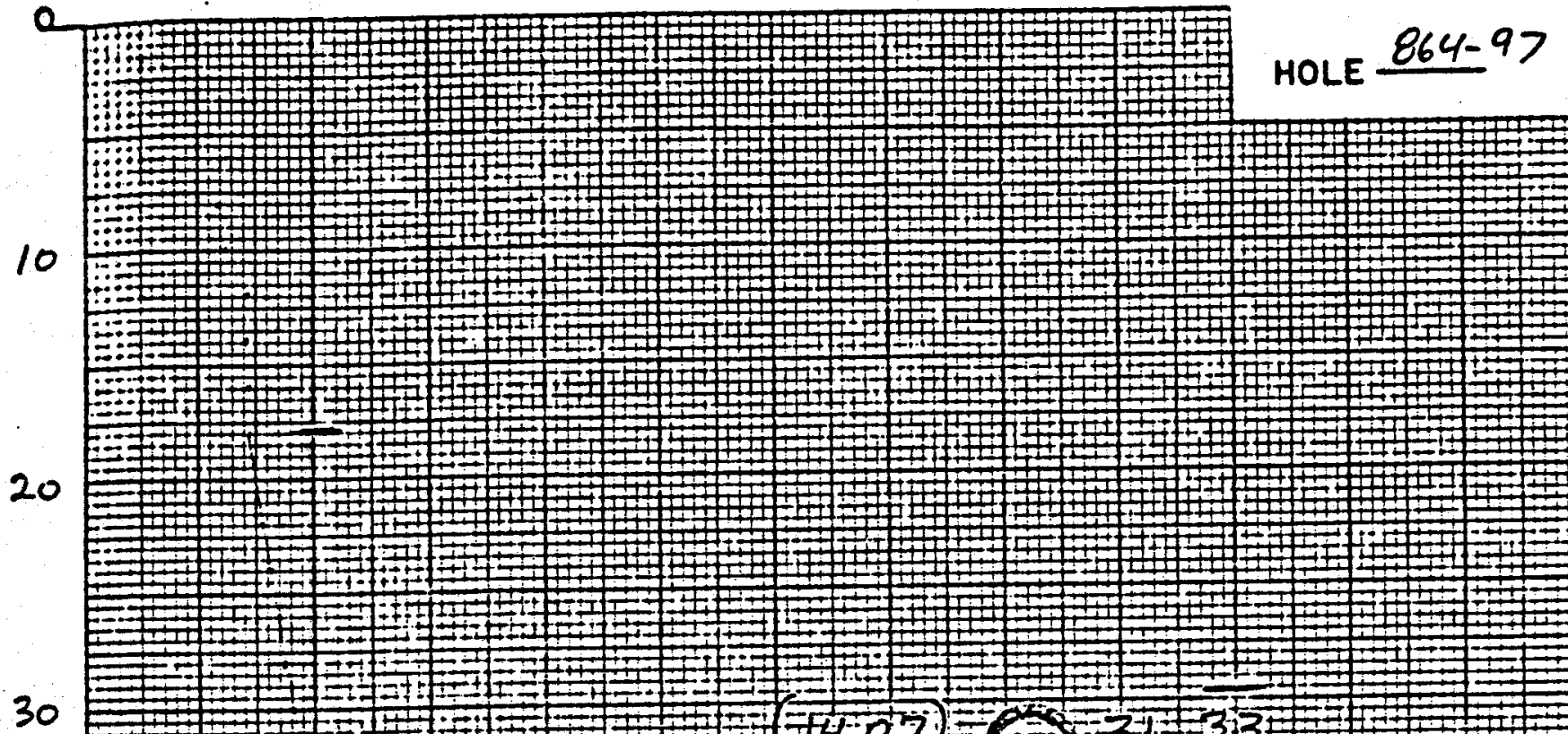

$7 \pm 1+7079$

(1)

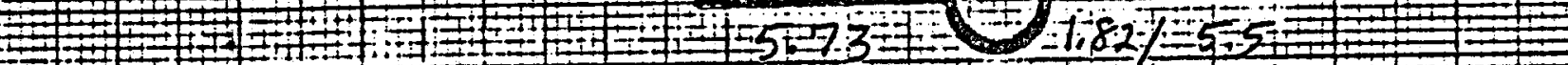
$1,82 \%=5,12$

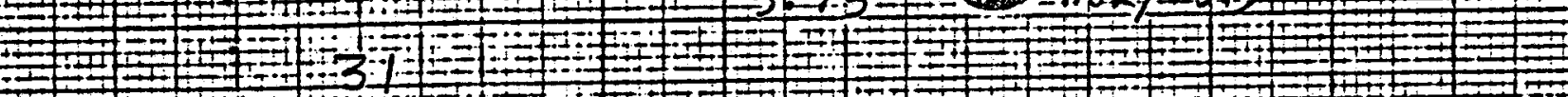

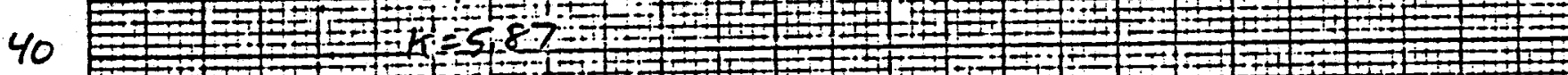

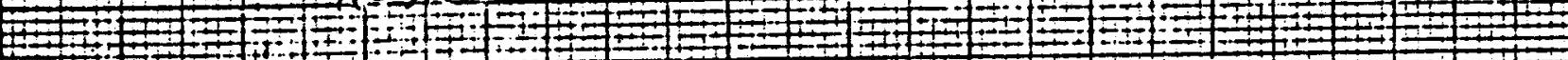

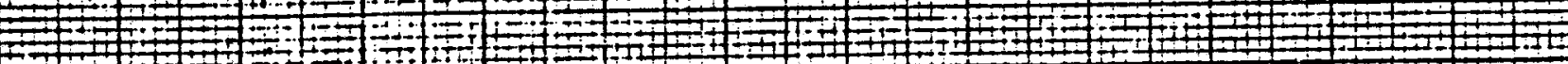

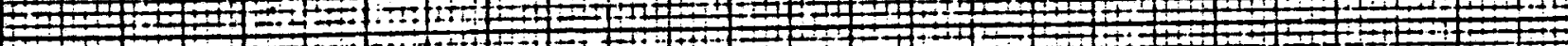

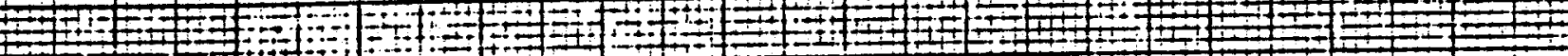

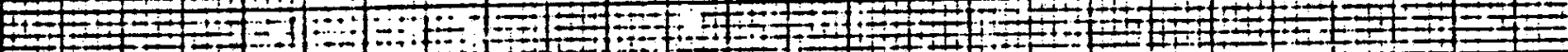

50

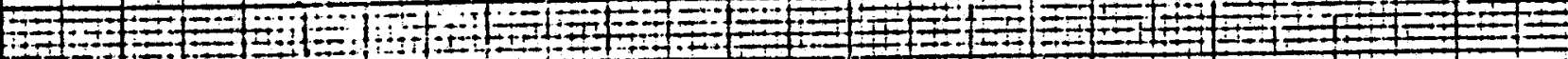

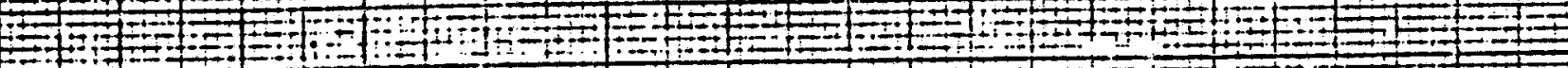

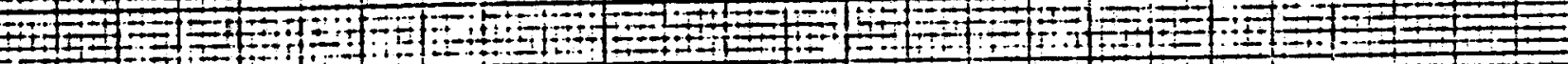

60

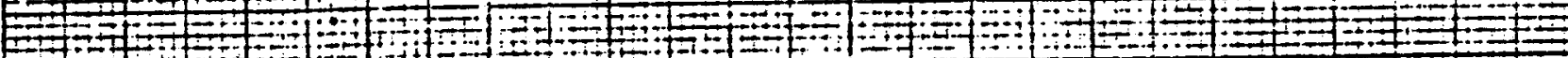
DEPTH 60

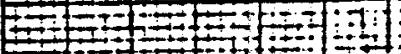

$\geq 1+1$

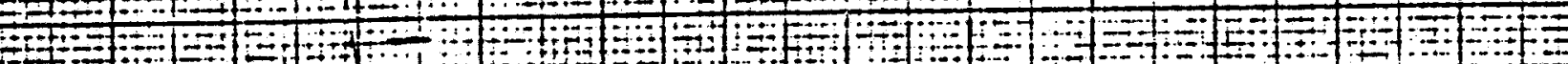

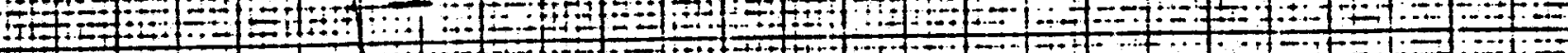
f

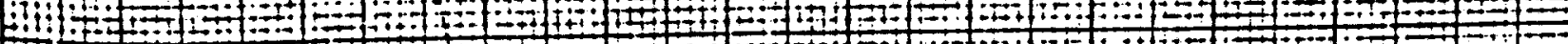

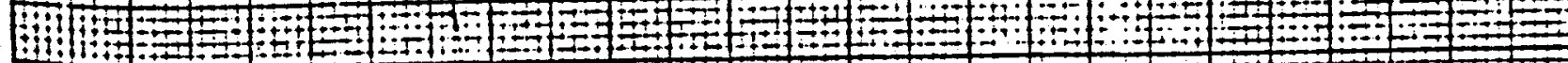

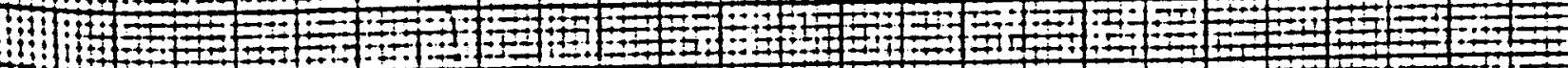
10 $11 \quad 12 \quad 13 \quad 14$ 15 $16 \quad 17$ 18 $19 \quad 20 \quad 21$ 22 
Date Logged: $05 / 27 / 81$

$\Delta$ T Well No.864-97

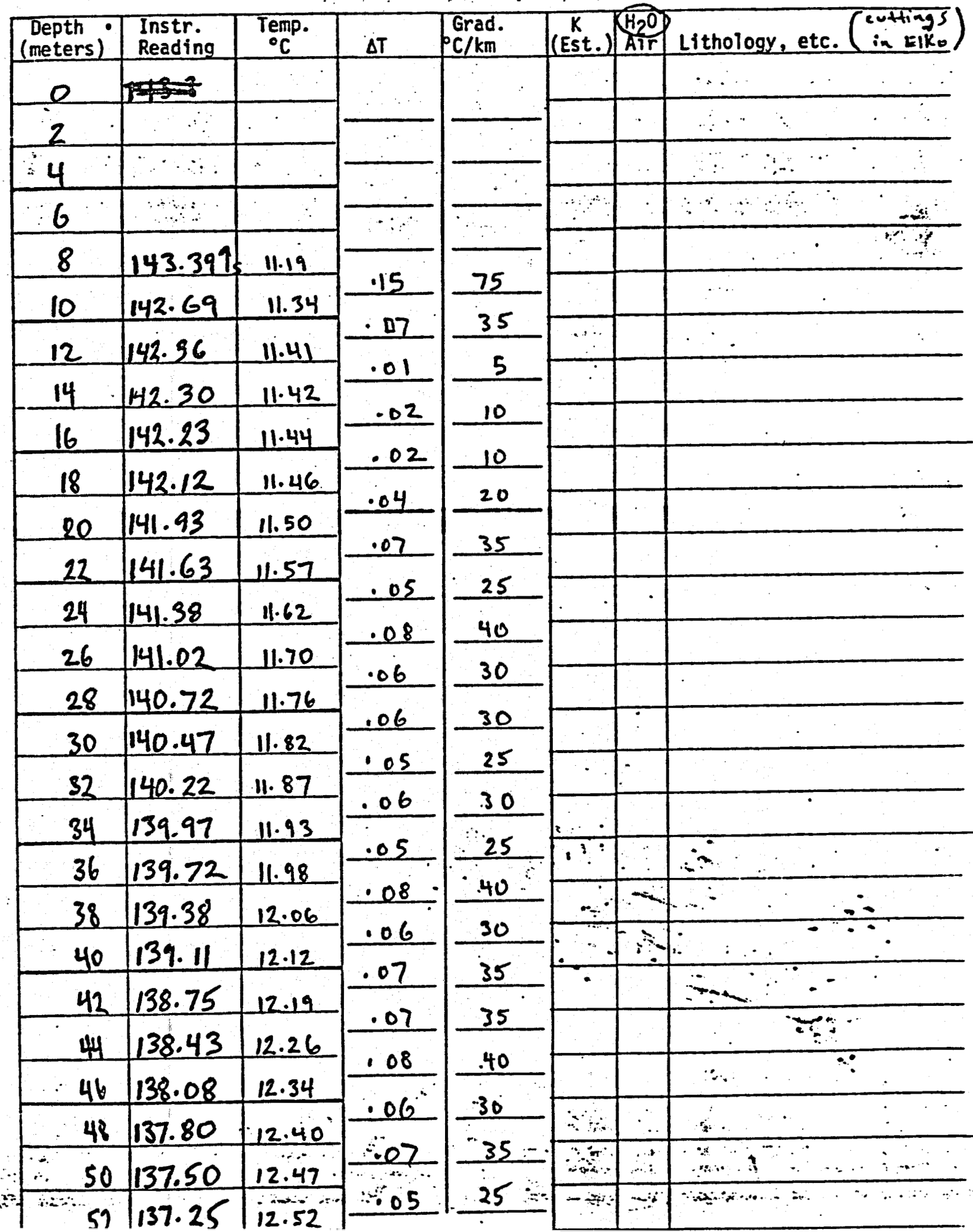




\begin{tabular}{l} 
Project: \\
Hole: \\
LITHOL \\
\hline
\end{tabular}

McCoy

Elevation: 5265

Date Drilled: $\quad 4-6-81$

Location: NWSW 35 T23N R40E

Method:

rotary air

Geologist: Deymonaz

Gamma:

Depth (m) Description

0-55 Alluvium - tan, sandy silt with angular to subrounded gravels of chert and welded tuffs with lesser amounts of iimestone and quartzite.

55-95 Tuff - latitic, hard, 1t. gray to red, aphanitic groundmass with $15 \%$ phenocrysts of feldspars, minor quartz, trace of magnetite and biotite. Common manganese deposition along small tight fractures. Note - considerable uphole sluffing throughout hole, tuff comprises about $50 \%$ of cuttings in this interval but are broken and angular while gravels from alluvium are slightly rounded. May represent tuff unit or larger tuff boulders. 
AMAX EXPLORATION, INC.

TEMPERATURE/DEPTH LOG

Property-project MCCOY - 864 Mapgilbert $C_{k}$ sw scale $71 / 2$ state NV county Elko of of of of of Instrument SPAFFRD \#46 Operator S.E.D. /M.A.

$\Delta$ Tell No884-99 Depth Logged 25 mo ? of Sec Logged $5-7-81$ $23 \mathrm{~N}_{\mathrm{R}} 40 \mathrm{O}$ Elevation 5040 ( 㹂) Comments MINERAL HOLE IN DLGGINS ON ALTERTTION TREWS $S$ OF ML COY MINE.

\section{$\therefore$ Date Logged}

iTUSTIFY Proj No Well No DA MO YR

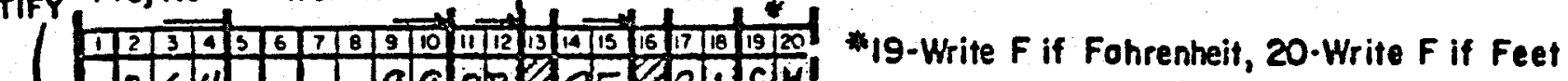

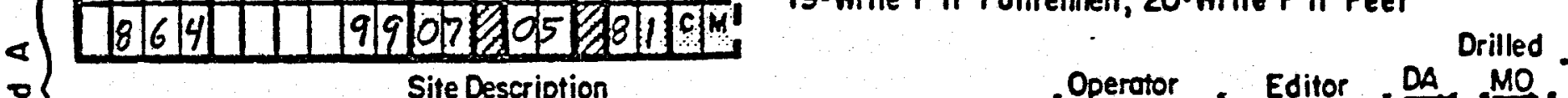

:

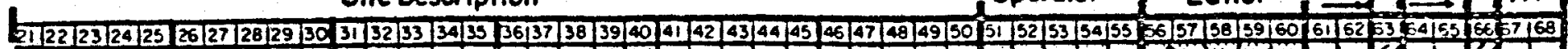

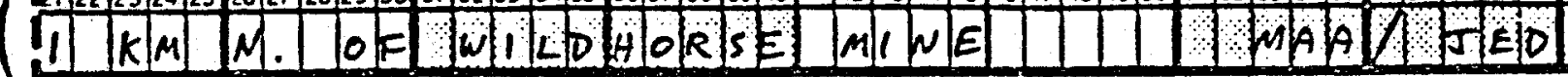
(Approx. locot ion, woter welli?, oil test?, etc).

(1)

Mop Location * *

Scak Unit MopSize NLat WOP Locotiong W W

IN, $(7.5,15,60)$, Degree, Min, Degree, Min * Meceure from SW

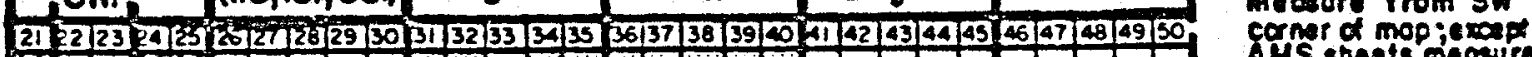

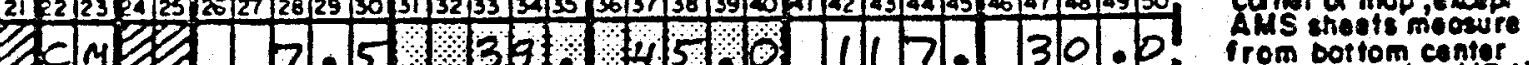

$\infty$

$\infty$

总

Use decinals

Grom dottom conjug

Northing

Eosting

Elev

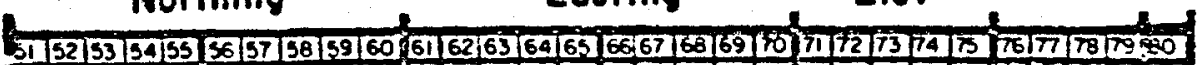

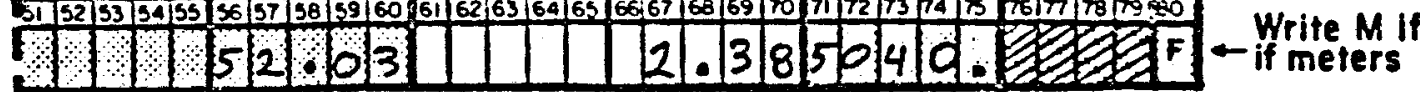

Use docimele

Segment $:=$ Depths

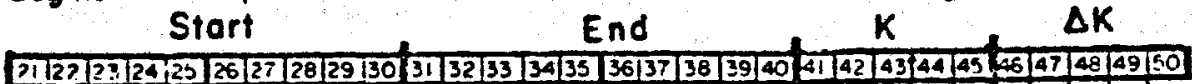

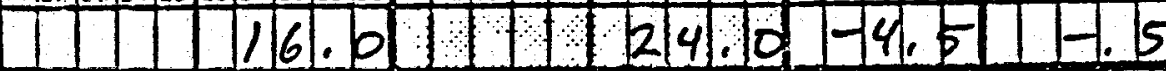

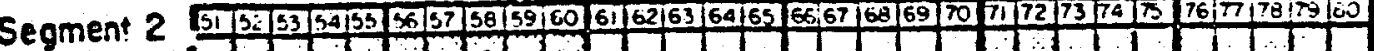

Segment 3

Stort $\longrightarrow$ i

पDI

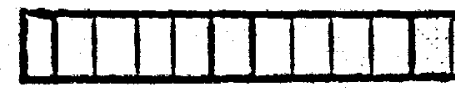

Segment 7

Segment 6

पाDI

Segment 9

Sion $\longrightarrow$ :

Segment 4

Start

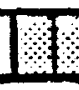

Segment 8

Start

8

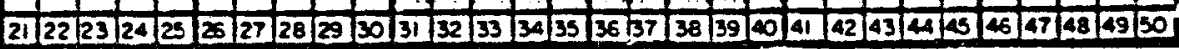

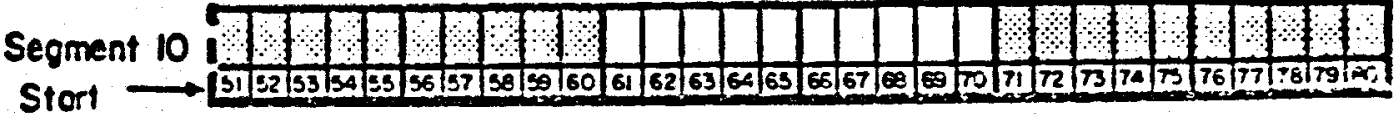

Best cond. (-K)

Downward extropolations

$(-\Delta K)$ 


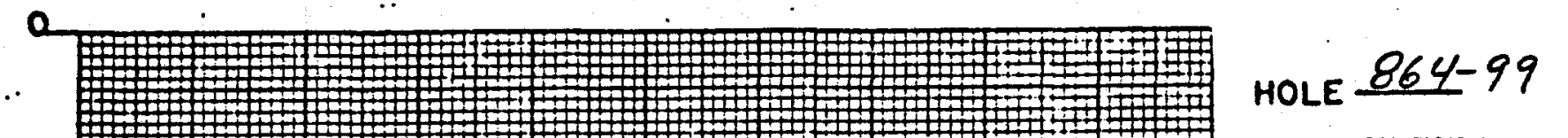

10

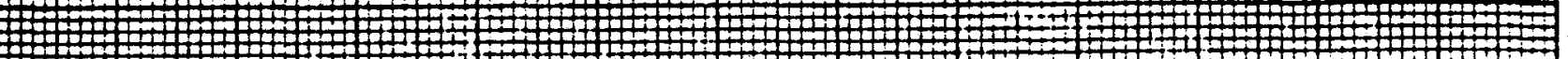

20

30

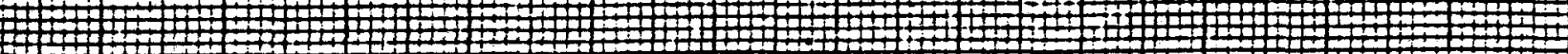

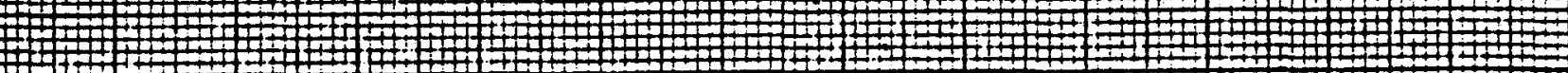

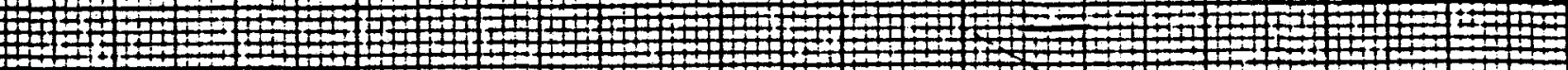
W

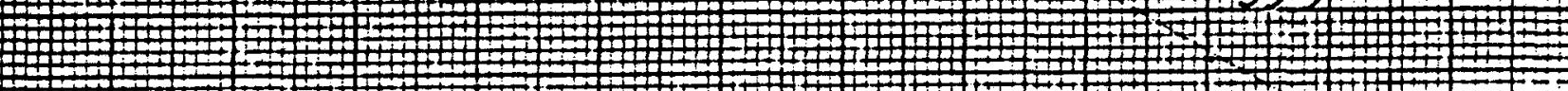

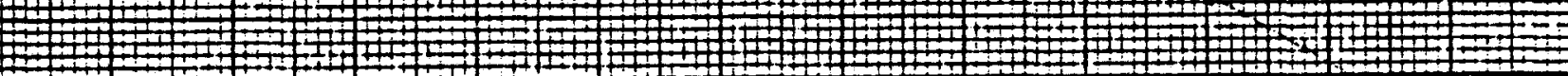

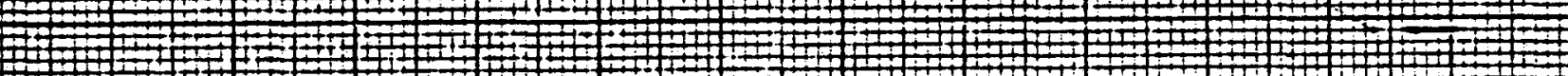
W

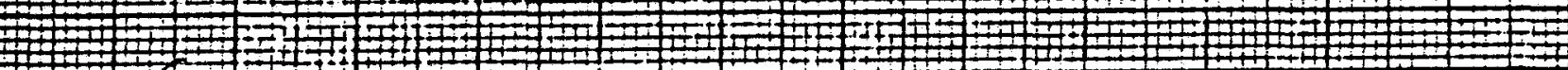

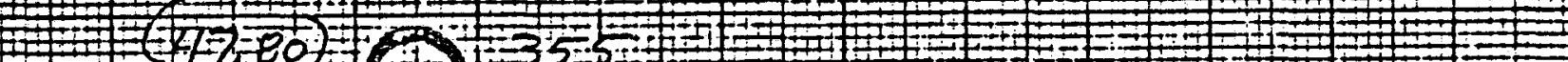

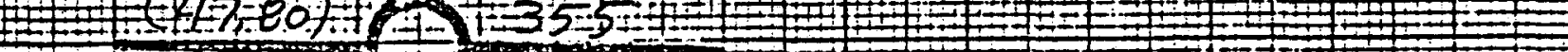

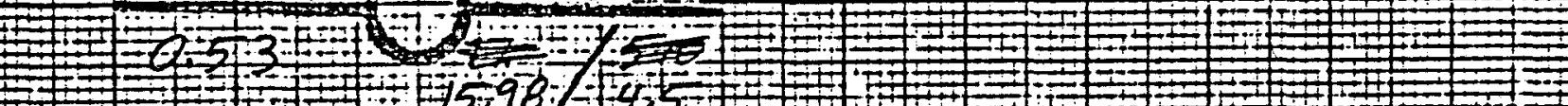

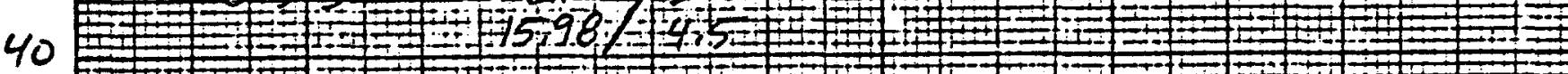

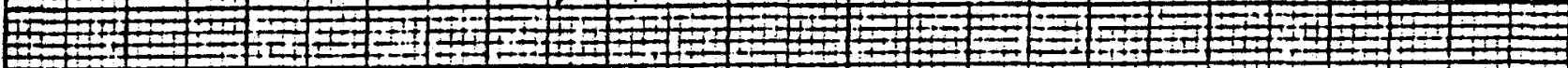

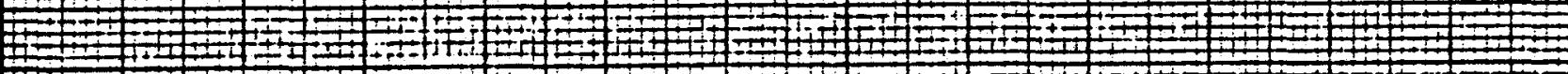

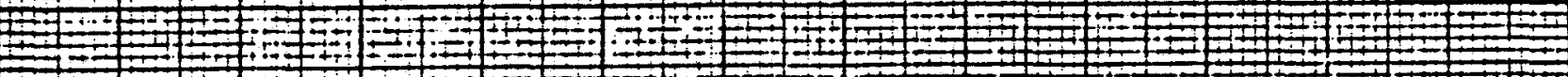

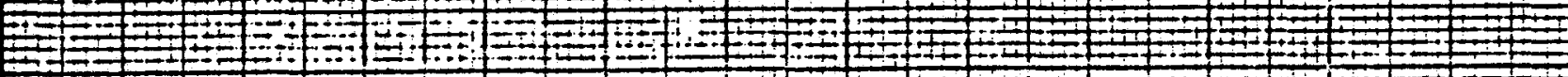

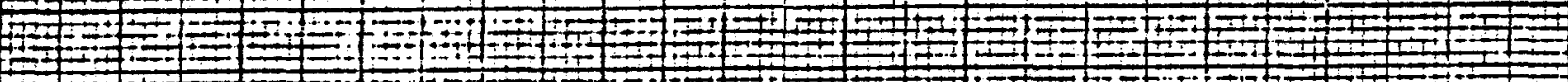

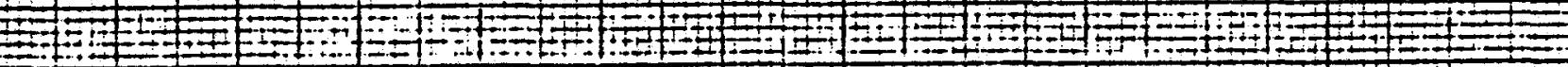

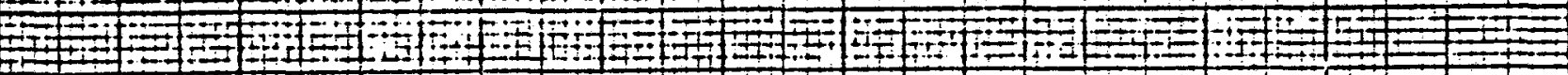

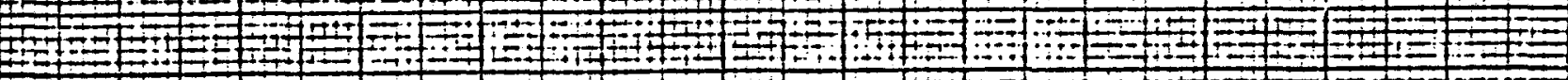

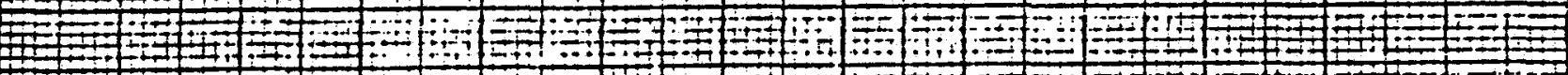

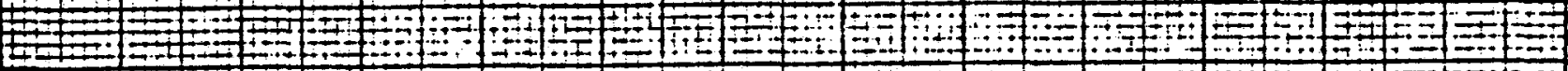

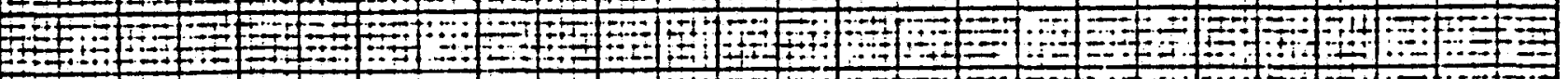
Fof

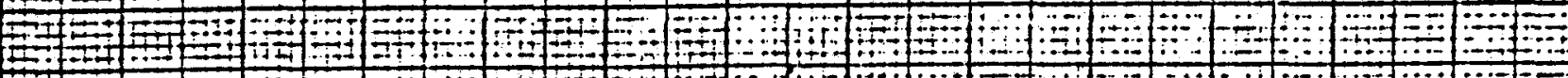

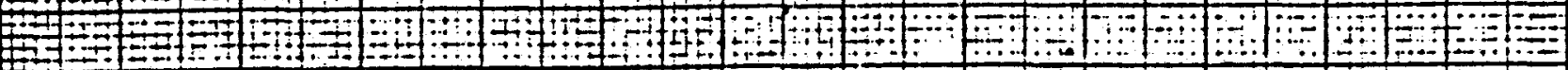

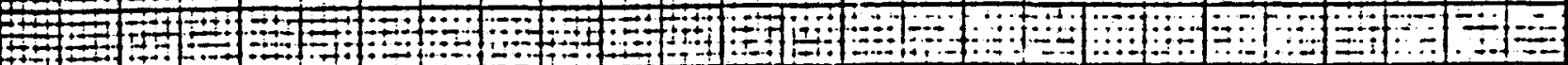

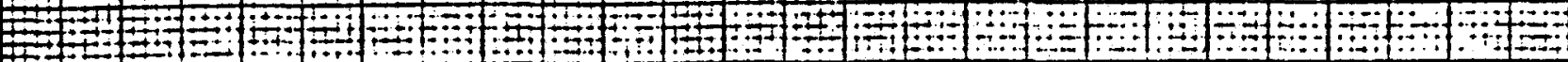

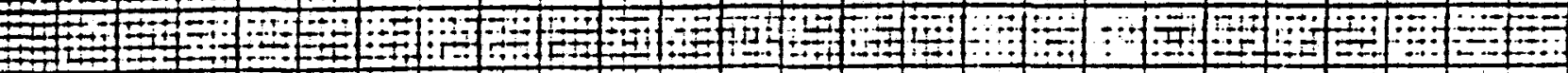
-

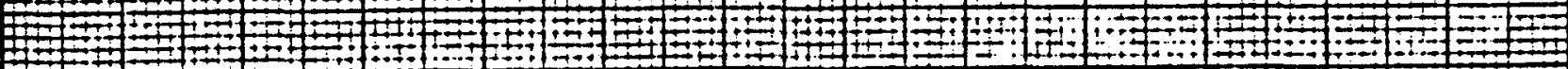

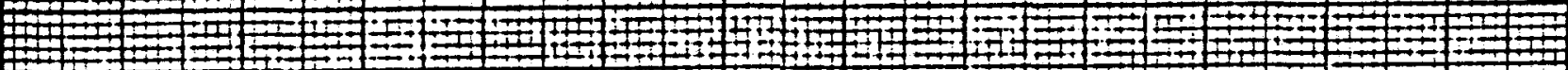

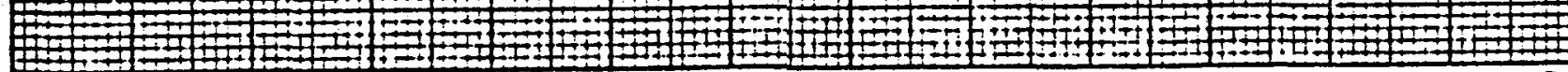

$\begin{array}{lllllllllllllllllllllllll}10 & 11 & 12 & 13 & 14 & 15 & 16 & 17 & 18 & 19 & 20 & 21 & 22 & 23\end{array}$




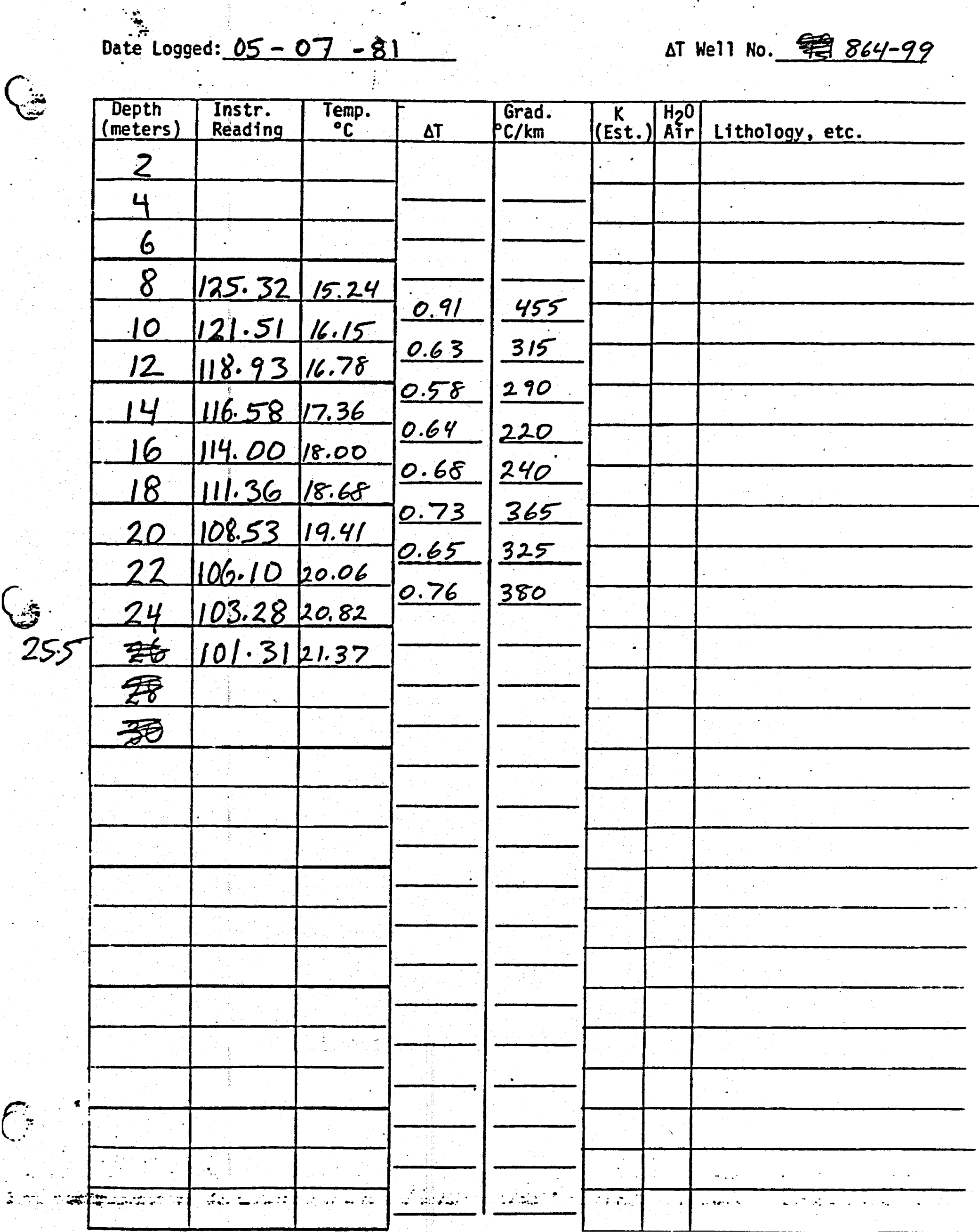

